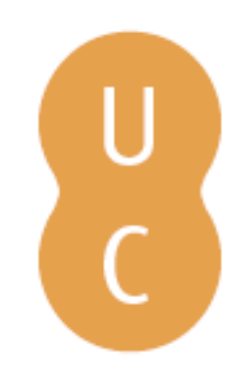

\title{
pompalina
}

\section{Sentimento e conhecimento na poesia de Camilo Pessanha}

Autor(es): $\quad$ Almeida, João Paulo Barros

Publicado por: Centro de Estudos Clássicos e Humanísticos; Imprensa da Universidade Pe Coimbra

URL

persistente: URI:http://hdl.handle.net/10316.2/2367

DOI: $\quad$ DOI:http://dx.doi.org/10.14195/978-989-721-061-7

Accessed : $\quad$ 26-Apr-2023 16:26:20

A navegação consulta e descarregamento dos títulos inseridos nas Bibliotecas Digitais UC Digitalis, UC Pombalina e UC Impactum, pressupõem a aceitação plena e sem reservas dos Termos e Condições de Uso destas Bibliotecas Digitais, disponíveis em https://digitalis.uc.pt/pt-pt/termos.

Conforme exposto nos referidos Termos e Condições de Uso, o descarregamento de títulos de acesso restrito requer uma licença válida de autorização devendo o utilizador aceder ao(s) documento(s) a partir de um endereço de IP da instituição detentora da supramencionada licença.

Ao utilizador é apenas permitido o descarregamento para uso pessoal, pelo que o emprego do(s) título(s) descarregado(s) para outro fim, designadamente comercial, carece de autorização do respetivo autor ou editor da obra.

Na medida em que todas as obras da UC Digitalis se encontram protegidas pelo Código do Direito de Autor e Direitos Conexos e demais legislação aplicável, toda a cópia, parcial ou total, deste documento, nos casos em que é legalmente admitida, deverá conter ou fazer-se acompanhar por este aviso.

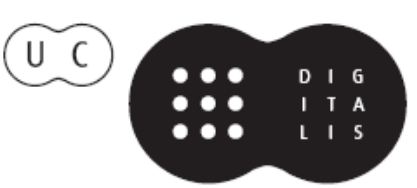




\title{
SENTIMENTO \\ e Conhecimento \\ NA Poesia de \\ Camilo Pessanha
}

\author{
JOÃO PAULO \\ ALMEIDA BARROS
}

\author{
IMPRENSA DA \\ UNIVERSIDADE \\ DE COIMBRA \\ COIMBRA \\ UNIVERSITY \\ PRESS
}





\title{
Sentimento \\ e Conhecimento \\ na Poesia de \\ Camilo Pessanha
}

\author{
JOÁO PAULO \\ ALMEIDA BARROS
}

IMPRENSA DA

UNIVERSIDADE

de Coimbra

CoImbra

UNIVERSITY

Press

Annablume 
Todos os volumes desta série são sujeitos a arbitragem científica independente.

Autor: Joáo Paulo Barros de Almeida

Título: Sentimento e Conhecimento na Poesia de Camilo Pessanha

Editor: IMPRENSA DA UnIVERSIDAdE DE COIMBra

AnNablume

EDIÇÃO: 1.a/2009

Coordenador Científico do Plano de Ediçấo: Maria do Céu Fialho

Conselho Editorial: José Ribeiro Ferreira, Maria de Fátima Silva,

Francisco de Oliveira, Nair Castro Soares

Director técnico da COlecçáo: Delfim F. Leáo

CONCEPÇÁo GRÁFICA E PAGINAÇÃo: RODOLFo LoPES

IMPRESSÁO:

Simóes \& Linhares, Lda.

Av. Fernando Namora, n. ${ }^{\circ} 83$ - Loja 4

3000 COIMBRA

Obra REALIZADA No ÂMbito DAS ACTIVIDADES DA UI\&D

Centro de Estudos Clássicos e Humanísticos

UniversidAde De CoImbra

FACULDADE DE LeTras

TeL.: 239859981 | FAX: 239836733

3000-447 CoImbra

ISBN: 978-989-8281-18-0

ISBN DigITAL: 978-989-721-061-7

DOI: http://dx.doi.org/10.14195/978-989-721-061-7

Depósito Legal: 303925/09

Obra Publicada com o Apoio de:

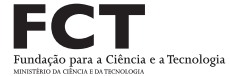

POCI $/ 2010$

@ Imprensa da Universidade De Coimbra

@ Annablume

Reservados todos os direitos. Nos termos legais fica expressamente proibida a reprodução total ou parcial por qualquer meio, em papel ou em edição electrónica, sem autorização expressa dos titulares dos direitos. É desde já excepcionada a utilização em circuitos académicos fechados para apoio a leccionação ou extensão cultural por via de e-learning. 


\section{ÍNDICE}

Prefácio

A gLóRIA DO POETA

Parte I. Linguagem, Sujeito e Simbolismo

1. Cinco perspectivas sobre a obra de Pessanha 13

2. Linguagem e Mundo 14

3. Ponto de vista crítico sobre a "desconstrução» 21

4. Poesia, verdade e beleza 26

5. Em torno de dois conceitos periodológicos, Decadentismo e Simbolismo 29

5.1. A eclosão gaulesa do Decadentismo e do Simbolismo 31

5.2. Excurso: Schopenhauer e Pessanha 37

5.3. A volúpia da decadência e as palavras-chave do Simbolismo 41

6. Análise da crítica a Flores de Coral de Alberto Osório de Castro 51

7. Decadentismo e Simbolismo na Clepsidra 56

Parte II. Subjectividade, Sentimento e Conhecimento

na poesia de Camilo Pessanha

\begin{tabular}{ll} 
1. As figuras da instância lírica & 71 \\
\hline 1. O coraçaon
\end{tabular}

1.1. O coração $\quad 78$

1.2. A alma $\quad 78$

$\begin{array}{ll}\text { 1.3. Os olhos } & 79\end{array}$

2. Sobre o sentimento $\quad 80$

2.1. Gemüt e Stimmung, a «verdade» romântica 83

3. Amor, companheirismo e conhecimento intersubjectivo 88

$\begin{array}{ll}\text { 4. A melancolia e os seus objectos } & 104\end{array}$

5. "A distância sem fim que nos separa»: a unidade cognoscitiva impossível 124

6. Um estranho absoluto 131

7. Observaçóes breves sobre o estilo de Pessanha 134

$\begin{array}{ll}\text { Conclusão } & 139\end{array}$

$\begin{array}{ll}\text { BibLIOGRAFIA } & 145\end{array}$

$\begin{array}{ll}\text { ÍNDICE ONOMÁsTICO } & 151\end{array}$ 
(Página deixada propositadamente em branco) 


\section{Prefácio}

Ocorreu-me escrever sobre Camilo Pessanha depois de ter presenciado a recitação do rondel, "Ao longe os barcos de flores", pelo Professor Doutor José Carlos Seabra Pereira, numa cadeira do Mestrado em Poética e Hermenêutica. A grande beleza desse poema acordou em mim reminiscências de mais de três lustros, pois já havia lido e desfrutado da poesia do autor de Clepsidra. Porque não, pensei eu, estudar a sua obra, indagar das causas da magia da sua poesia?

Abalançando-me a essa tarefa, poderia trilhar um de dois caminhos: ou, depois de ler a obra, estudar as focagens mais significativas de críticos e escoliastas, tentando abrir uma vereda no meio da floresta das interpretaçôes ou ler directamente a obra e construir sobre ela um ponto de vista, ignorando as abordagens sedimentadas na história da sua recepção, aligeirando o texto final. Escolhi naturalmente o primeiro caminho pois não queria repetir sem o saber e inabilmente pontos de vista já elaborados magistralmente, não seguindo o conselho de Schopenhauer, autor muito aludido, justificadamente, como se verá, neste estudo, de ler primeiro o criador e só muito depois, após haurirmos as nossas próprias conclusóes, ler o expositor ou o crítico.

Deste modo as primeiras páginas deste estudo remetem largamente para críticos e autores de méritos amplamente reconhecidos, o que pode redundar numa vantagem deste livro: uma introdução arrumada das perspectivas, direi, já clássicas sobre a poesia deste autor. Para quem considere muito minucioso o jogo citacional, só tem que passar ao largo das primeiras páginas.

Como este trabalho se inseriu no âmbito de um curso que unia literatura e filosofia, estava tacitamente autorizado a tentar fazer uma leitura de coloraçáo «filosófica» da poesia de Pessanha. Daí, em ordem em pôr em evidência a sua dimensão cognoscitiva, ter-se operado um desvio que incidiu sobre a disputada capacidade de abertura da linguagem relativamente ao seu fora, e que referiu as flutuações que as categorias de representação, mimesis e realidade apresentavam na poética do Simbolismo. Defendeu-se que a inserção da poesia de Pessanha em certas coordenadas do Simbolismo é válida, não obstante a recusa do autor em filiar-se em escolas. Pôs-se em destaque o seu principal artigo crítico em que se podem surpreender os lineamentos básicos de uma poética pessoal. $\mathrm{O}$ alto conceito em que Pessanha tinha a poesia repousava 
na convicção de que esta arte, a ser fiel à sua essência, tinha que ser pura e filosófica e, por inerência, cognoscente.

Seguindo este eixo interpretativo, visou-se a problemática do conhecimento latente nos poemas de Pessanha. Foi possível distinguir um conhecimento teorético, reflexivo, que incide, também, sobre a fenomenologia da percepção e um outro, tingido pelo «sentimento». No amplo leque dos sentimentos, considerei que a «melancolia» feria a nota dominante dos seus poemas. A feição estruturante da "melancolia» condiciona a indagação sobre o que podemos conhecer e o que podemos esperar. A resposta negativa a estas magnae quaestiones não apaga a intensidade da interrogação. A poesia de Pessanha é, em larga medida, animada por uma intenção ontológica que desemboca, contudo, na dolorosa conclusão de não ser capaz de apreender o ser.

Dizia um filósofo norte-americano, George Santayana, que a ideia de "que a vida é digna de ser vivida constitui a mais necessária das proposiçốes e a mais impossível das conclusôes». Para quem, como eu, persiste em crer que essa conclusão é possível, enfrentar grandes pessimistas como Pessanha constituiu uma prova cuja ultrapassagem robustece essa perseverança.

Agradeço particularmente ao Prof. Doutor José Carlos Seabra Pereira, com quem aprendi muito mais do que as páginas que se seguem podem revelar. Teria que agradecer a tantos outros que receio que mais três ou quatro páginas náo bastariam, excedendo dessa maneira, imperdoavelmente, a brevidade obrigatória de um prefácio. Ainda assim, não posso deixar de exprimir a minha gratidão à coordenadora do Mestrado em Poética e Hermenêutica, Prof. Doutora Maria do Céu Fialho, bem como ao Centro de Estudos Clássicos e Humanísticos da Universidade de Coimbra e aos Classica Digitalia por haverem, graciosamente, tornado possível esta publicação.

Coimbra, Dezembro de 2009 João Paulo Barros de Almeida 


\section{A gLória do POETA}

Na nota à segunda edição (1981) do seu marcante estudo, $A$ "Clepsidra» de Camilo Pessanha, observava Esther de Lemos que Camilo Pessanha seria «talvez o menos conhecido e estudado dos grandes poetas portugueses $\aleph^{1}$. Uma das razóes que logo se apontou, posteriormente, para tal descuido prende-se com o nosso complexo liliputiano: fora Pessanha francês (no momento actual, no ano da graça de 2009 , dir-se-ia preferentemente «inglês» ou «norte-americano») e a glória do poeta reverberaria por todo o orbe literário... Esta conjectura foi aventada por Arnaldo Saraiva ${ }^{2}$, a que Christine Pâris-Montech ${ }^{3}$ acrescentou mais três razóes: o poeta ele mesmo, nada dado a afadigar prelos literários, a prevalência da imagem de um desterrado opiómano, metamorfose decadentista do poète maudit, que terá escondido a obra e, the last but not the least, «le jaloux monopole» de Joano de Castro Osório que teria desencorajado outros especialistas a envolverem-se mais profundamente com a obra do poeta.

Mas o mesmo não se pode dizer de Fernando Pessoa, a quem se pode aplicar o que August-Wilhelm Schlegel afirmava de Camóes: que vale toda uma literatura. Aliás, a propósito, a situaçáo menor de Camilo Pessanha tem sido explicada pelo gigantismo ofuscador do universo pessoano: a árvore tapou ou escondeu a floresta (sustenta-se frequentemente que fenómeno similar explica a

${ }^{1}$ Esther de Lemos, $A$ «Clepsidra» de Camilo Pessanha, Lisboa, 2a ed., Editorial Verbo, 1981, p. 9.

${ }^{2}$ Arnaldo Saraiva, "Fonte contínua de exaltação estética», in Persona, 10, Porto, 1984, p. 4.

${ }^{3}$ Christine Pâris-Montech em L'Imaginaire de Camilo Pessanha Résonances Fin-de-Siècle et Hantises Individuelles, Paris, Centre Culturel Calouste Gulbenkian, 1997, p. 17. 
menoridade dos autores dramáticos isabelinos contemporâneos de Shakespeare). Deve-se, contudo, registar que na história do destino literário de Pessanha, é possível observar oscilaçóes de «fama» que se prendem, obviamente, com as condiçôes mentais e culturais de cada geração ou época, as "tendências» dominantes. A este respeito, Paulo Franchetti assinala aquilo que um crítico, Pedro da Silveira, tinha já posto em relevo: a publicação de dezasseis poemas de Pessanha, na Centauro (1916), constituiu «o ponto de partida para o reconhecimento de Pessanha como um grande poeta», sendo «um dos sinais desse reconhecimento" a «antologia Os Cem Sonetos de poetas portugueses e brasileiros, feita por Mayer Garção nas colunas do diário A Manhã (1919?) e depois apresentada em livro ( $1^{a}$ ed., 1920). Pessanha é representado por nada menos de cinco sonetos, todos transcritos da revista de Luís de Montalvor $»^{4}$. A fama de Pessanha excede assim o âmbito de círculos intelectuais e artísticos, por natureza, restritos. Naquele campo, a irradiação do autor na geração modernista é enorme, a qual o elege como Mestre geracional. António Ferro proclama arrebatadamente: «a nossa geração tem um missal. Saiu o livro de Camilo Pessanha. A alma de todos nós, desnorteada, tem, enfim, um relógio" 5 .

Náo obstante, se concordarmos com Óscar Lopes, que «nalguns casos, Pessoa serve, bem lido, de introdução ex post à poesia, bem mais cerrada sobre si mesma, do mestre» ${ }^{6}$, não se poderá ler na (re)descoberta de Pessanha um efeito lateral, retrospectivo, do «século pessoano»? É que, de facto, essa situação de relativo «olvido», a que Esther de Lemos se referia, modificouse totalmente. Os anos oitenta e noventa viram sair a lume numerosos artigos e estudos sobre o poeta e a obra, concordes na afirmação da grandeza do poeta. São de destacar os testemunhos de Mário Cesariny e Eugénio de Andrade. Este último repete o que Pessoa ${ }^{7}$ havia proclamado: «Mas de todos estes poetas

${ }^{4}$ Cf. Paulo Franchetti, O Essencial sobre Camilo Pessanha, Imprensa Nacional-Casa Da Moeda, 2008, p. 44.

${ }^{5}$ Cit. por António Quadros em «Introdução biográfica e crítica», in Obras de Camilo Pessanha, Clepsidra e poemas diversos, Introdução biográfica e crítica, Organizaçấo e Notas de António Quadros, Lisboa, Publicaçóes EuropaAmérica, 1988, p. 43.

${ }^{6}$ Óscar Lopes, «Pessanha, o quebrar de espelhos», in Ler e Depois, Porto, Ed. Inova, 1970, p. 208.

7 «Estas palavras que são nada bastam para apresentar a obra do meu mestre C. P. O mais que é tudo, Camilo Pessanha», cit. por António Quadros em «Introdução biográfica e crítica», in Clepsidra e poemas dispersos, Lisboa, Publicaçôes Europa-América, 1988, p. 27. 
[Pessoa, Pessanha, Cesário, Camóes], creio que Camilo Pessanha é o único que amei em segredo como um mestre» ${ }^{8}$. As afinidades entre Pessoa e Pessanha ultrapassam o campo temático, podendo radicar-se ao nível psicológico ou caracteriológico: na primeira carta escrita a Ana de Castro Osório (1893), pode ler-se - «Vem daqui, penso eu, a minha falta de alegria e este fenómeno de todas as minhas sensaçóes terem sido antes pensamentos...»?. Noutra carta, a Alberto Osório de Castro, insinua que o excesso de inteligência o tornou infeliz, bem como aos seus amigos - «Eu tinha ouvido dizer o Alberto Osório uma vez "a minha irmá é demasiado inteligente”. Seria um pouco da [lacuna] que me tem feito infeliz e tem feito infelizes os meus amigos?» ${ }^{10}$.

Outra convergência com Pessoa está na ideia de infância, entendida mais como símbolo de um paraíso perdido, de uma felicidade remotíssima, do que como um estádio concreto, factual, efectivamente vivido - «(...) até à minha infância virtual, pois que eu não me lembro de ter tido uma infância (há muitos cismáticos que nascem velhos) ${ }^{11}$. Aproxime-se, por outro lado, a expressão "loucura lúcida», recolhida numa carta a Henrique Trindade Coelho ${ }^{12}$ com, por exemplo, o verso de Álvaro de Campos, «Estou doido a frio». Pessoa não reconhece, contudo, a influência da poesia de Pessanha sobre a do seu amigo Mário de Sá-Carneiro num gesto de denegaçáo em que ele próprio estaria em causa. Pelo menos, é o que pensa Cabral Martins, vendo nesta atitude uma manifestação da "ansiedade da influência», título de uma obra de Harold Bloom ${ }^{13}$.

Reposta então a glória devida, importa passar em revista os principais focos hermenêuticos de abordagem da obra do autor em apreço.

${ }^{8}$ Eugénio de Andrade, «Camilo Pessanha, o mestre», in Persona, 10, Porto, 1984 , p. 10.

9 In António Osório, O Amor de Camilo Pessanha, Mafra, Ediçôes Elo, 1982 , p. 22.

${ }^{10}$ Camilo Pessanha, Contos, Crónicas, Cartas escolhidas e Textos de temática chinesa, Organização e notas de António Quadros, Lisboa, Publicações Europa América, 1988, p. 87.

${ }^{11}$ Ibidem, "Carta ao pai», p. 75.

${ }^{12}$ Ibidem, p. 114.

${ }^{13}$ Cf. Fernando Cabral Martins, «Pessanha e Sá-Carneiro: intersecçôes», in Colóquio/ Letras, no 117/ 118, 1990, p. 195. 
(Página deixada propositadamente em branco) 
PARTe I

Linguagem, Sujeito e Simbolismo 
(Página deixada propositadamente em branco) 


\section{1- Cinco perspectivas sobre a obra de Pessanha}

Sem embargo do esquematismo, podem-se elencar em cinco grandes perspectivas: a linha psicologizante, entrelaçando biografia e obra, a simbólica, sob a égide de Bachelard e Gilbert Durand, a histórico-literária, inscrevendo Pessanha, seja na atmosfera do fim-de-século, seja no movimento simbolista, a textual (estilística e/ou estrutural), reportando-se prioritariamente à tecelagem sintáctica, rítmica, prosódica da poesia do autor e a interpretação "vestigial/ espectral», de clave derridiana ${ }^{1}$.

Acresce, como espécie do terceiro género referido, a que, articulando Decadentismo e Simbolismo, elege a superação simbolista dos elementos decadentistas como via de acesso ao âmago da poesis, da experiência poética de Pessanha. Este último ponto de vista tem sido desenvolvido pelos trabalhos de José Carlos Seabra Pereira, nomeadamente no seu comentário ao rondel «Ao Longe Os Barcos De Flores» ${ }^{2}$. Como concreçóes das perspectivas antes apontadas, podem-se indicar como ilustraçáo da biografista uma «Introduçáo biográfica e crítica»" ${ }^{3}$ de António Quadros, na qual este autor pontilha os principais acontecimentos biográficos de Pessanha com correspondentes poesias, pressupondo a unidade, a seu ver, incomparável, entre vida e obra («Talvez nunca entre nós, como em Camilo Pessanha, tenham sido tão coincidentes os princípios de uma escola (a do simbolismo decadentista) com a realidade biográfica de uma existência humana. Por isso, na sua poesia, as imagens simbólicas nunca são artificiais, têm uma autenticidade indesmentível» ${ }^{4}$, e também o livro de João Gaspar Simóes, Camilo Pessanha ${ }^{5}$ d da simbólica, os estudos de Álvaro Cardoso Gomes ${ }^{6}$, e de Christine Pâris-Montech, já referido; da terceira, por exemplo, o livrinho de Barbara Spaggiari ${ }^{7}$; da

${ }^{1}$ Cf. Gustavo Rubim, «Imaginar Pessanha», in Arte de Sublinhar, Coimbra, Angelus Novus, 2003, pp. 39-43.

2 In Século de Ouro Antologia Crítica da Poesia Portuguesa do Século XX, Organização de Osvaldo Manuel Silvestre e Pedro Serra, Coimbra, 2003, pp. 263-274.

3 In Clepsidra e poemas dispersos, Lisboa, Publicaçôes Europa-América, 1988.

${ }^{4}$ Ibidem, p. 49.

${ }^{5}$ João Gaspar Simóes, Camilo Pessanha, Lisboa, Arcádia, 1967.

${ }^{6}$ Álvaro Cardoso Gomes, A metáfora cósmica em Camilo Pessanha, S. Paulo, Faculdade de Filosofia, Letras e Ciências Humanas, 1977.

${ }^{7}$ Barbara Spaggiari, O Simbolismo na Obra de Camilo Pessanha, Lisboa, Instituto de Cultura e Língua Portuguesa, 1982. 
quarta, o estudo pioneiro de Esther de Lemos, já referido, cuja abordagem é deste modo formulada: «Tomar a poesia feita, como fruto da árvore, sem biografia e sem história» ${ }^{8}$ e os trabalhos de Óscar Lopes que não prescinde, porém, do factor biográfico, fazendo até remontar áreas do campo imaginário de Pessanha aos seus progenitores e respectiva origem social: "filho tardiamente legitimado de um magistrado de linhagem aristocrática e de uma serviçal com quem conviveu uma parte da infância, Camilo Pessanha parece conservar na poesia, vindo do lado paterno, um abstracto sonho de passadas eras cavaleirescas, e do lado materno uma saudade mais concretamente pessoal da vida aldeã, de onde vêm as suas imagens mais impressivas (...) notemos que, em seu parecer, o vero lirismo é sempre bucólico, o que nele quer dizer materno» ${ }^{9}$, e da quinta, os trabalhos de Gustavo Rubim ${ }^{10}$.

Obviamente, estas linhas de leitura não são paralelas reciprocamente intangíveis, mas linhas predominantes. Por exemplo, no artigo abaixo citado, Gustavo Rubim, cujo trabalho carreia modelos teóricos de análise dimanados do pós-estruturalismo, descortina no isolamento do motivo do «espectro» e das «imagens fantasmáticas», operado no estudo de Christine Pâris-Montech, uma importante deslocação que desborda o quadro psicologizante e que ele próprio desbravou ${ }^{11}$. Demais, no estudo da crítica francesa, se emaranham as três primeiras linhas apontadas.

Chegados a este ponto, convirá indagar em que esteira se inscreve esta despretensiosa dissertação. Que ângulo se análise se privilegiará? Antes de responder directamente a esta questão, convém efectuar um breve desvio sobre o principal dos pressupostos teóricos.

\section{2- Linguagem e Mundo}

Mantemos a ideia tradicional da linguagem como intermediário entre o homem e as coisas, rejeitando-se consequentemente a tendência pós-moderna que afirma ou sugere que fora do texto

${ }^{8}$ Esther de Lemos, op. cit., p. 14.

9 Óscar Lopes, "Camilo Pessanha», in Entre Fialho e Nemésio, Vol. I, Lisboa, INCM, 1987, p. 119.

${ }^{10}$ Designadamente, A Inscrição Espectral: Poética do Vestígio em Camilo Pessanha, Dissertação de Doutoramento, Universidade Nova de Lisboa, Lisboa, 1998. 43.

${ }^{11}$ Cf. Gustavo Rubim, «Imaginar Pessanha», in Arte de Sublinhar, pp. 42, 
não há nada e a consequente absolutização do texto como único terreno da interpretaçáo. Por outras palavras, a teoria que defende que a nenhuma realidade ou instância $a b$ alio, exterior ao texto, se pode outorgar a capacidade de determinar ou esclarecer o sentido do texto, por a linguagem se bastar a si mesma.

Porém, sustentar a transitividade fundamental da linguagem (escrever é transitivo ${ }^{12}$ ) não equivale a pré-determinar totalidades significativas e plenas de que o texto seria a reprodução. $\mathrm{O}$ outro do texto pode muito bem ser o múltiplo ou a dispersão. Mas declarar a demissão da consciência ou do eu ou do indivíduo ou da vontade ou ainda o caos ou o nada essencial de tudo pressupóe a posição do que se recusa ou ultrapassa. Se pensar é dizer não, na frase famosa de Alain, na qual se pode ver uma das muitas modulaçóes do imperativo da heterodoxia (revolta, diferença, jogo, desordem e acaso, utopia da tábua rasa, etc.) que domina a situação espiritual do "nosso tempo» (ocidental), o "não» não opera no vazio, não há rebeldes sem causas: o princípio anarquista dá objectos à negação ou recusa: nem Deus, nem Mestre e seus resíduos.

Poderá parecer inoportuna esta digressão, mas não destoa do coro, quer dizer, nas teorias estruturalistas e pós-estruturalistas do texto e da linguagem palpita esse espírito de negação e de rebelião, nomeadamente, na tentativa de aniquilar o «autor», entidade em que ainda subsistiria a velha e perigosa aspiração metafísica de encontrar a presença, o fundamento seguro e tranquilizador, o sentido pleno, etc.

Discriminando na linguagem a expressão oral da expressão escrita, verifica-se que a passagem do discurso oral ao escrito modifica o papel das instâncias intervenientes do discurso, mas não elide a intencionalidade primigénia da linguagem, tal como se patenteia nos actos de fala: dizer algo (sentido) sobre algo (referência - as categorias de Frege: Sinn e Bedeutung) a alguém (comunicação). Essas instâncias ou factores foram discriminados por Jakobson num esquema célebre: locutor, ouvinte, meio, código, situação, mensagem. Com a inscrição escrita, desfaz-se a situaçáo dialógica, o face a face, as marcas materiais substituemse à voz, a intenção mental do emissor deixa de coincidir com o significado verbal do discurso, o leitor, de qualquer época, sucede ao ouvinte, a referência torna-se não situacional, não ostensiva... A verificação do alcance destas alteraçóes conduz à revisão do

${ }^{12}$ Vira-se do avesso a conhecida frase de Barthes: «escrever é intransitivo». 
cânone tradicional (não só da hermenêutica romântica, mas da tendência espontânea de qualquer interpretação) de validação da interpretação textual: o reconhecimento ou a identificaçáo do que o autor quis dizer. Se o critério da intenção textual perdeu o seu carácter decisivo (mas não para o autor de Validity in Interpretation, E. D. Hirsch, que identifica no significado verbal imutável pretendido pelo autor o fundamento da interpretação correcta ou válida), tal não significa, na nossa opinião, que a biografia ou a psicologia do autor (real) tenham perdido toda a relevância. Permanecem dados a combinar com outros de ordem estilística ou estrutural, consoante a competência literária, o caldo de expectativas do leitor. Permanecerão pontos de vista distintos, mas que nada impede, nuns textos e nuns autores mais do que em outros, evidentemente, de se complementarem. O conhecimento da data de produçáo de um poema, das circunstâncias de diversa ordem que a envolveram, pode contribuir para a interpretaçáo do poema, desde que não se lhe atribua um papel mecanicamente causal e exclusivo. No acto de leitura, sobretudo de poesia lírica, sucede não raro aos leitores perguntarem-se sobre o que é que o poeta pretende dizer com isto ou aquilo. É preciso, na verdade, uma ascese muito sofisticada para colocar entre parênteses o autor, para emudecê-lo, para prescindir do impulso de tentar adivinhar a sua intenção subjectiva.

Daí que a linguagem seja mediação entre homem e mundo, dupla abertura, ponte de duas margens. O signo não é apenas diferença interna do significante e do significado, mas referência externa à coisa (ou ser ou mundo ou vida...).

Há assim palavras e coisas. E o sujeito que profere ou escreve as palavras.

Com efeito, a figura do autor ressurge até da pena daqueles que a colocaram sob suspeita. Um Pessoa, cuja obra em tantos pontos prefigura «a morte do autor», decorrente da abolição do «dogma da personalidade» ${ }^{13}$ (o que náo impediu que tivesse escrito biografias e horóscopos dos heterónimos, caindo no velho «logro» de julgar que a biografia de algum modo explica a obra), advertiu que «o que é preciso é compenetrarmo-nos de que, na leitura de todos os livros, devemos seguir o autor e não querer que ele nos siga $»^{14}$.

13 «Não sou eu que escrevo. Eu sou a tela/ E oculta mão colora alguém em mim.», poema XI de "Passos da Cruz», in Fernando Pessoa, Poesias, Lisboa, Ática, 1992 , p. 55.

${ }^{14}$ Fernando Pessoa, Páginas Íntimas e de Auto-interpretação, ed. por Jacinto do Prado Coelho e Georg Rudolf Lind, Lisboa, 1966, p. 116. 
Se o sujeito se descobre sub-jectum, canal de um outro, anónimo, neutro ou pessoal, di-lo, dizendo-se. É preciso que algo exista para que algo seja dito, do lado do sujeito e do lado do objecto. Pois quem pretende não significar, afinal significa ${ }^{15} \ldots$ Ou, como diz, Umberto Eco, «não há nada mais significativo, que um texto que afirme o seu próprio divórcio do sentido» ${ }^{16}$.

$\mathrm{Na}$ verdade, a célebre «função poética» recortada por Jakobson, a que infla a face palpável dos signos, náo é privada de poder referencial: «A supremacia da função poética não oblitera

${ }^{15}$ Esta frase é retirada do ensaio «Sociologia sumária de uma ressurreiçáo» de Eduardo Lourenço ("Essa vontade de não significar, significa», p. 75), in Heterodoxia II, Lisboa, Gradiva, 2006, pp. 72-82. O objectivo do ensaio é o de situar o êxito epocal do existencialismo (Sartre, Camus...) na trama do movimento espiritual ocidental do desencanto, da estranheza e alienação do homem moderno no mundo, de que o existencialismo constitui um prolongamento, uma variação (é significativo que a epígrafe escolhida seja uma citação de Valéry, herdeiro, como se verá, da vertente, digamos, formalista-nihilista do simbolismo: «Le monde au sein duquel nous nous sommes formés à la vie et à la pensée est un monde foudroyé. Nous vivons comme nous pouvons dans le désordre de ses ruines, ruines elles-mêmes inachevées, ruines que menacent ruines»). No domínio artístico, esse processo tem a direcção de uma progressiva desumanização das artes na análise célebre de Ortega y Gasset, cujo estádio último pode, entre outros exemplos, ver-se nas cores e formas de certa pintura moderna que não se referem senão a si mesmas, "cuja significação é não significarem nada, como diz Georges Braque», ibidem, p. 74. Lourenço assinala o óbvio, quando constata que o absurdismo de Sartre e Camus tem muitos predecessores, entre os quais elege Pessoa, o poeta da hora absurda. Também seria perfeitamente congruente pôr Pessanha na genealogia - cf. «(...) Não sei onde vou./ Roteiro da Vida,/ Quem é que o traçou?», «Não sei de onde venho», "Miragens do nada/ Dizei-me quem sou...», em «Enfim, levantou ferro»[Roteiro da Vida I], in Camilo Pessanha, Clepsidra e outros poemas, Edição crítica organizada por Barbara Spaggiari, Porto, Lello Editores, 1997, p. 170. Todos os poemas citados reportam-se a esta edição crítica. Dado o exíguo corpus poético do autor, e para não fazer proliferar as notas, optámos por prescindir da indicação das páginas em que se encontram os poemas.

Sobre as vantagens "poemáticas» da manutenção de uma ortografia arcaizante, cuja «iconicidade» rima com as intençôes manifestadas pelo poeta e com as coordenadas do Simbolismo, ver Paula Morão, «Edição crítica de textos modernos e contemporâneos: algumas questôes gerais, seguidas de notas breves sobre Clepsidra», in Românica, 15, 2006, sobretudo as páginas 70,72 e 76.

${ }^{16}$ Umberto Eco, "Introdução», in Os Limites da Interpretação, Lisboa, Difel, 1992, p. 18. Não poderíamos conceber mais sonora confirmação deste paradoxo que temos respaldado com citaçóes de ilustres pensadores do que o remate de um artigo de Pires Laranjeira sobre o autor em apreço: «A lição de Pessanha: a Ausência, o Vazio, o Nada, também significam» (Pires Laranjeira, "Música e abulia em Camilo Pessanha», in Persona, 10, Porto, 1984, p. 39). 
a referência, mas torna-a ambígua. A uma mensagem de duplo sentido corresponde um destinador duplicado, um destinatário duplicado e, além disso, uma referência duplicada...» ${ }^{17}$. Por outros termos, a redução da poesia à função poética e vice-versa equivale a uma simplificaçáo errónea. Por mais largo que seja o rio as margens estáo lá, mesmo quando não se vêem, ou seja, o texto ou a obra não são absolutos, mas ocupam o termo médio de uma dialéctica: autor/ obra/ receptor.

Todo o acto linguístico é por natureza comunicacional. Esquecer esta condição é fossilizar a linguagem. Temendo este perigo, advertia Jakobson: "As pesquisas que têm tentado construir um modelo de linguagem sem qualquer relação com o locutor e o auditor e que hipostasiam assim um código separado da comunicação efectiva, correm o risco de reduzir a linguagem a uma ficção escolástica» ${ }^{18}$.

Assim, as conjecturas interpretativas não são todas equivalentes, do próprio texto deflui a injunção de o seguir. Se o New Criticism advertia contra o perigo da falácia biográfica, ou falácia da intenção, nos termos de W. K. Wimsatt e C. M. Beardsley, opostamente, Ricoeur identificou a falácia do texto absoluto. A este respeito, Eco, que declarara na introduçáo de Os Limites da Interpretação pretender restabelecer a inevitabilidade da oscilação entre a fidelidade à obra e a iniciativa do intérprete, perante a tendência coetânea de pender o prato da balança para o lado da iniciativa do intérprete, numa verdadeira mutação de paradigma (diríamos, simplificando: da sintaxe para a pragmática), correndo o risco de agora parecer demasiado respeitoso em relação ao texto, quando, por ocasiáo de Obra Aberta, teria dado a impressão do contrário, pôe como visée da conjectura do leitor/ intérprete a intentio operis. Recordando que o debate hermenêutico tradicional opunha dois programas, procurar no texto o que o autor queria dizer ou o que ele diz, independentemente das suas intençôes, a sua aposta caminha na senda deste segundo programa (tal como em Ricoeur, a intenção mental do autor empírico é declarada inapreensível, fantasmática), ancorando in medio virtus de entre os três tipos de intençóes, a intentio auctoris, a intentio operis e a intentio lectoris, na coerência textual o critério de validação, a chave da interpretação, o ponteiro da balança ${ }^{19}$.

\footnotetext{
${ }^{17}$ Cit. in Paul Ricoeur, Metáfora Viva, Porto, Ed. Rés, 1983, p. 334.

${ }^{18}$ Cit. in Eco, Os Limites da Interpretaçâo, pp. 26, 27.

${ }^{19}$ Cf. Eco, op. cit., pp. 27-31.
} 
Repare-se que se os que denunciam a vaidade e o orgulho subscrevem os seus discursos, também os que proclamam a morte do autor reclamam a autoria desse lema. Se nada soubéssemos de um Cervantes ou de um Dostoiéwski, a leitura das suas obras não nos dariam uma imagem, lábil é certo, mas delineável do feixe de interesses do homem de carne e osso que as escreveu? E, daqueles autores cuja biografia náo deixou qualquer traço, logo vem a lenda e a conjectura preencher o lugar vazio. Pense-se, neste caso, em Homero, e em Shakespeare ou Camóes, também, nos rios de hipóteses biográficas, jogadas a partir das obras.

Nunca a obra literária é totalmente um disfarce, e mesmo que seja essa a sua intencionalidade, a máscara, no acto de esconder, revela, sendo sempre possível perguntar o que é que o disfarce disfarça ou encobre.

No caso vertente, acrescenta efectivamente à inteligibilidade de poemas como "Quem poluiu, quem rasgou» e "Canção da Partida», o conhecimento de episódios biográficos, por mais transposta que seja a poesia de Pessanha ${ }^{20}$. A biografia e a psicologia do autor permanecem factores importantes, mas não suficientes na decifração do texto. Uma interpretação válida pode ter em conta os dados psico-biográficos. Não é insignificante reparar na intromissão elocutória da palavra «Eu» justamente no primeiro verso de Clepsidra.

Mas se o factor biográfico é completamente extrínseco à compreensão do texto, se o autor morreu, que interessa então determinar se João de Castro Osório terá arrogado para si o papel de co-autor de alguns versos do poeta, além do pormenor filológico? É uma conclusão impecavelmente lógica do princípio da «morte» do autor, tal como é formulada, radicalmente, por Jean-Louis Baudry: «Dans cette perspective, le sujet, cause de l'écriture, s'évanouit et l'auteur, l'"ecrivain", avec lui. L'écriture ne "représente" pas la "création" d'un individu isolé; elle ne peut

${ }^{20}$ Em contrapartida, principalmente numa poesia não-confessional como a de Pessanha, é imprudente definir com muita precisão os referentes reais dos enunciados poéticos. Um exemplo de reducionismo biográfico pode ser encontrado na pena de Cabral Martins, o qual, ao arrepio da sugestão simbolista que perfilha, clama que a «luz», o "país perdido» e a «alma...lânguida e inerme» de "Inscrição" indicam respectivamente o ópio, a China e o opiómano deitado na sala de fumo, apud Gustavo Rubim, A Inscrição Espectral: Poética do Vestígio em Camilo Pessanha, Dissertaçáo de Doutoramento, pp. 39-41. Ficou célebre a réplica de Fernando Pessoa a João Gaspar Simóes sobre a identidade do sino da minha aldeia: «o sino da minha aldeia, ó Gaspar Simôes, é o da Igreja dos Mártires, ali no Chiado». 
pas être considérée comme sa propriété, mais bien au contraire à travers un nom qui n'est déjà que fragment textuel, elle apparaît comme une des manifestations particulières de l'écriture générale. [...] Pleynet l'a bien montré à propos de Lautréamont, ce n'ést pas un "auteur" qui signe une "oeuvre", mais un texte qui signe un nom» ${ }^{21}$. O sujeito de um determinado texto é, não um indivíduo escritor, mas a escrita universal e ilimitada. Conversáo gráfica da Ideia de Hegel, a escrita é como a aranha que tira de si própria a teia. Não está explicado, porém, como a astúcia da écriture elege uns indivíduos em detrimento de outros.

A redução da literatura a um jogo diferencial entre signos conduz à insustentável situação de «agora, ninguém fala para ninguém sobre coisa nenhuma $»^{22}$.

Por outro lado, a imagem predominante do poeta revela também o intérprete e o horizonte deste: ao poeta sem escrita, ficçáo por muito tempo mantida, mas que como se diz das lendas tem um grão de verdade, sucedeu o poeta da escrita... Não será substituir um mito por outro ${ }^{23}$ Esta oscilação de imagem confirma o facto de que, na tarefa interpretativa do leitor/intérprete, como tem sido realçado pela Estética da Recepção, intervém a sua historicidade, o seu horizonte de expectativas, a intentio lectoris.

A propósito desta problemática, meramente esboçada, retivemos uma frase, na recensão crítica do livro Flores de Coral, da autoria do seu amigo Alberto Osório de Castro, em que Camilo Pessanha afirmava admirativamente que «no remoto isolamento de Timor, onde não chegam os ecos das estéreis polémicas das

${ }^{21}$ Cit. in Vítor Aguiar e Silva, Teoria da Literatura, Coimbra, Almedina, 1988, pp. 244, 245.

22 W. R. Johnson, cit. por Rubim, A Inscrição Espectral..., p. 112, que rebate evidentemente os princípios da lírica defendidos por aquele e esta verrinosa conclusão.

${ }^{23}$ No processo desta inversão, passou João de Castro Osório de salvador a viláo, ou, como se diz no futebol, de bestial a besta - cf. Alfredo Margarido, "Camilo Pessanha, poeta da escrita», in Persona, 11/ 12, Porto, 1985, pp. 76-84. Este autor acusa João de Castro Osório de ter desvirtuado a obra de Camilo Pessanha, fazendo persistir a impostura de, não fora a sua insistência devota, jamais Pessanha teria cedido em trasladar para a escrita os poemas que guardava na memória. Deselegantemente, lança máo do argumento ad hominem, tornando-se até muito pessoal no seu ataque. Além de ser de extremadireita, o catolicíssimo João de Castro Osório não podia suportar a ideia de que «o poeta, que em tempos pretendera a mão, e o corpo, de sua mãe, D. Ana de Castro Osório, fosse capaz de tais construçóes poéticas anti-católicas» [os sonetos «A Miragem» e "Transfiguração»], mascarando o seu conteúdo ao apor-lhes o título de «Dois sonetos de satírica imitação» (ibidem, p. 77). 
coteries, um único intuito orienta o seu labor espiritual; realizar por meio da verdade, a beleza ${ }^{24}$.

Neste juízo de valor podemo-nos deter nos primeiros segmentos e do objecto da crítica extrapolar para o seu sujeito: ao isolamento de Timor se pode sobrepor o isolamento, menos insular, é verdade, de Macau, e no pairar acima das contendas de coteries literárias nos píncaros da poesia pura reconhecer a atmosfera almejada por Camilo Pessanha para a respiração da sua poesia.

No entanto, o que tine mais agudamente, a leitores do século XXI, é a presença desses conceitos fortes: a beleza, a verdade. Com efeito, o esboroamento destes conceitos no plano filosófico e dos estudos literários (e outros termos-conceitos que gravitariam em torno da metafísica ou onto-teologia, como: representação, fundamento, essência, presença, ordem, princípio, autor, sujeito, homem, teoria, verdade, sistema, etc...) tem sido levado a cabo, no delta da modernidade, pelas correntes de pensamento que se reclamam, entre outros, de Nietzsche.

Dessas correntes avulta, também pela grande influência que tem exercido nos estudos literários, de que constitui notável exemplo a Dissertação de Doutoramento de Gustavo Rubim, a "escola filosófica» da "desconstrução", fundada por Jacques Derrida. Por isso, não será deslocada uma referência ao seu "espírito», perspectivado por nós pelo viés das lentes críticas de Jürgen Habermas ${ }^{25}$.

\section{3 - PONTO DE VISTA CRÍTICO SOBRE A «DESCONSTRUÇÃO»}

$\mathrm{Na}$ esteira de Heidegger, de que se reclama discípulo e continuador, Derrida visa a metafísica ocidental e a filosofia do sujeito, o seu antropo-logo-centrismo, sustentando que o essencial da linguagem é atingido através do modelo da escrita e não da fala. Sendo o logos consubstancial à palavra falada, à voz ( «A voz é capaz de mostrar o objecto ideal ou o significado ideal... sem se perder numa aventura fora da idealidade ou fora da interioridade da vida presente em $\mathrm{si}^{26}{ }^{26}$, fonocentrismo e logocentrismo

${ }^{24}$ Camilo Pessanha, Contos, Crónicas, Cartas escolhidas e Textos de temática chinesa, Organização e Notas de António Quadros, Lisboa, Publicações Europa América, 1988, p. 155.

${ }^{25}$ Cf. o cap. «Exacerbação da Filosofia Temporalizada da Origem: A Crítica de Derrida ao Fonocentrismo», in Jürgen Habermas, O Discurso Filosófico da Modernidade, Lisboa, Publicações Dom Quixote, 1990, pp. 157-199.

${ }^{26}$ Cit. in ibidem, p. 170. 
convergem. Denunciar aquele é combater o último. À ciência da escrita chamará gramatologia que retira da autonomização do discurso escrito relativamente aos factores ou instâncias do discurso (autor, destinatário, etc. ${ }^{27}$ ), facto incontrovertível, a ideia de uma legibilidade absoluta, em que todo o grafema é legível ad infinitum em contextos que se modificam arbitrariamente.

Para a problemática que nos ocupa, é fácil de ver quais as consequências desta hipóstase lítica da escrita: Habermas não tem dúvidas de que Derrida «obrigou textos de Husserl, Saussure ou Rousseau a confessar coisas que vão contra a opinião explícita dos seus autores» ${ }^{28}$. John Searle vai mais longe, afirmando que «Derrida tem uma deplorável propensão para dizer coisas que são obviamente falsas» ${ }^{29}$.

Sobre o ensaio crítico do filósofo alemão, cujo pensamento pretende salvar a razão, na acepção, que caracterizaríamos como debole, duma razáo comunicacional e argumentativa ${ }^{30}$, diremos que é guiado pelo escopo de mostrar como o projecto de Derrida não se furta aos escolhos da filosofia do sujeito, que quer precisamente demolir ou «desconstruir», e que desemboca num confusionismo aporético entre as ordens ou esferas do discurso. Detecta-se o cuidado de notar as continuidades e as diferenças relativamente à filosofia heideggeriana.

Os encontros e desencontros de Derrida e Heidegger seriam um tema fascinante. Há, contudo, outros pontos deveras estimulantes da crítica de Habermas que se podem relacionar pertinentemente com o trabalho que se está a realizar.

Não referindo embora a concepção de Mallarmé de Livro, segundo o qual a obra náo começa, nem acaba, Habermas refere uma citação de Jaspers, feita por Derrida - «O mundo é o manuscrito de um outro mundo nunca inteiramente legível; só a existência o decifra» - logo acrescentando que Derrida priva esta

27 Vide nota 7.

${ }^{28}$ Habermas, op. cit., p. 181.

${ }^{29}$ Cit. in Eco, op. cit., p. 337.

${ }^{30}$ A sua filosofia pode condensar-se no título de um dos seus livros - Teoria do Agir Comunicacional, sendo uma das palavras-ordem do seu pensamento a defesa da validade da ordem do discurso da filosofia enquanto guardiã da razão: a filosofia da modernidade combina proposiçóes fortes, de acordo com os questionamentos universalistas próprios do discurso filosófico, com aspiraçôes estatutárias fracas, no sentido de que a filosofia há muito abandonou a incondicionalidade ou fundamentação última das suas respostas - «não existe um contexto nulo para as aspiraçóes à verdade», Habermas, op. cit., p. 199, nota 74 . 
imagem de qualquer laivo optimista ao radicalizar kafkianamente a ideia do livro perdido. Este livro escrito na caligrafia de Deus nunca existiu e os seus indícios também se dissiparam. Portanto, os vestígios da escrita que a modernidade procura são radicalmente insusceptíveis de se integrarem numa totalidade coerente como a escritura sagrada ou o livro da natureza.

Foram apontadas afinidades entre Derrida e correntes da tradição rabínica heterodoxa, que concordariam, simplificadamente, na adopção deste lema: esqueçam Deus, mas perpetuem a Torah, a Escritura ou a Lei na sua ambivalência. Os cabalistas tenderam a valorizar a Torah oral, os comentários humanos da palavra divina. A verdade deixa de ser fixa, é interpretável segundo o suceder das geraçóes. A própria Torah escrita seria uma tradução insegura da palavra divina para a linguagem dos homens, o que concita uma decifração interminável. Umberto Eco regista que os cabalistas medievais e renascentistas consideravam a Cabala não só como infinitamente reinterpretável, mas também como susceptível de ser reescrita de infinitos modos ${ }^{31}$.

Voltando ao texto de Habermas, o pensamento de Derrida, mutatis mutandis, recoloca-se na velha querela entre S. Paulo e os judeus, entre a presença viva, imediata de Cristo, do Logos divino e a escritura, o texto, a lei, a letra, "morta», segundo $S$. Paulo. De modo nenhum se insinua que Derrida dá vestes novas a um fundo religioso, no sentido convencional, teológico do termo: enfaticamente, declarou que não faz teologia, nem sequer teologia negativa.

Como heideggeriano, recusa-se sequer a considerar o ens summum - Abbagnano inclui este autor na classe dos teólogos do Anti-Deus, num oximoro polemizante, juntamente com Deleuze, Foucault, Klossovsky, Vattimo, no sentido em que o denominador comum destes autores seria a visão do mundo como desordem e acaso ${ }^{32}$.

$\mathrm{Na}$ sequência da inversão feita por Abbagnano, diríamos que Derrida póe no lugar de Deus a "différance», acontecer

${ }^{31}$ Sobre as relaçôes que se podem detectar entre $o$ modo hermético-gnóstico de interpretação e as teorias de interpretação pós-modernas, vide "A herança do hermetismo hoje», pp. 56-62; "Derivação hermética e semiose ilimitada", pp. 370-373 e «Semiose ilimitada e desconstruçáo», pp. 373-375, in Eco, op. cit.

${ }^{32}$ Nicola Abbagnano, Nomes e Temas da Filosofia Contemporânea, Lisboa, Dom Quixote, 1990, pp. 125-131. 
sem sujeito, diferenciação dos signos entre si por espaçamento, distensão - o motor da arqui-escrita que é origem an-árquica: a diferença «não comanda nada, não reina sobre nada e não exerce qualquer autoridade. Ela não é anunciada por nenhuma maiúscula. Não só não existe um reino da "différance" como esta fomenta a subversão de todo e qualquer reino» ${ }^{33}$. Ela é puro jogo, diferimento indefinido, espiral de interpretaçóes cuja regra é a de evitar a todo o custo a tentação da "verdade», a interpretaçáo unívoca e definitiva...

Quer dizer então que a história do ser de Heidegger (do seu esquecimento, mais propriamente) é transformada numa história da escrita, deriva de sinais que remetem labirinticamente para textos mais antigos, e aqui o pensamento de Derrida toca a ideia mallarmeana de Livro, derivação sem princípio nem fim, pois neste encadeamento não há possibilidade de remontar ao escrito originário.

Porém, esta tarefa sem fim à vista não é uma paixão inútil. O trabalho de desconstrução (a destruição da onto-teologia) é revolucionário, pois conduz à demolição de hierarquias, de relaçóes conceptuais de dominação como espírito/matéria, natureza/ cultura, inteligível/sensível, interno/ externo, homem/ mulher.

Daí que Derrida muito coerentemente inverta o cânone aristotélico da supremacia da lógica relativamente à retórica, donde decorre que, posto de lado o critério lógico da não contradição, obras de filosofia (e de ciência) possam ser abordadas como obras de literatura (a tradição hermética das interpretaçóes infinitas não marcava passo diante da contradição das interpretaçôes: a contradição é vista como uma aparência, uma camada de superfície de alegorias cujo sentido profundo aponta misteriosamente para uma unidade de fundo).

Interessa destarte, não a lógica da argumentação, mas o estilo, os expedientes retóricos com que o próprio texto filosófico e até o texto científico fazem estalar os seus conteúdos argumentativos explícitos. A abolição da autonomia, da diferença entre filosofia e literatura permite assim que textos filosóficos sejam escalpelizados dos seus conteúdos essenciais através de uma crítica literária.

No trajecto oposto, também os textos literários podem ser decifrados como textos filosóficos, o que redunda, afinal, na crítica e desmontagem da metafísica. A noção derridiana de um texto

${ }^{33}$ Cit. in Habermas, op. cit., p. 175, nota 43. 
geral dilui no seu seio as diferenças genéricas entre os âmbitos da filosofia, da ciência e da arte e da literatura ${ }^{34}$.

A difusão de Derrida nos E.U.A. desalojou o New Criticism como a teoria crítica dominante, pelo que a cientificidade que o New Criticism, nutrido pelos ideais formalistas, rígidos, do estruturalismo, atribuía à crítica literária é declarada irrelevante ou deslocada pelos «desconstrucionistas», sendo aberta a via para alijar a crítica literária da sua subserviência tradicional em relaçáo à literatura e colocá-la no mesmo patamar de criatividade da obra literária ${ }^{35}$.

A crítica de Habermas, chamando em seu socorro Austin, Searle, Jakobson, Richard Ohmann, contra J. Culler e Mary L. Pratt, passa pela desmesura que Derrida confere à estetização da linguagem, suprimindo-se a distinção entre a praxis normal e linguística do quotidiano e a esfera extra-quotidiana da ficção. Contudo, o nivelamento entre literatura (e crítica literária) e filosofia acaba no indesejável resultado de despojar uma e outra da sua substância.

A manifesta presença de ingredientes retóricos nestas duas ordens do discurso, bem como na linguagem normal, não deve fazer esquecer que os elementos retóricos cumprem funções diferentes consoante esses níveis. Os elementos retóricos permanecem em segundo plano da linguagem quotidiana e, na linguagem científica e técnica, estão subordinados à finalidade de resolver problemas (a tendência destes discursos é a de facilitar a comunicação, anulando o significante diante do significado, tornando o discurso o mais transparente possível), enquanto que na linguagem da ficção assumem um papel preponderante na descoberta do mundo, de um mundo outro que o da quotidianeidade, liberta dos constrangimentos comunicacionais e da estreiteza da situação da praxis linguística do quotidiano.

Um último ponto, que não achámos adventício registar: para Habermas, a crítica literária, ou mais globalmente a crítica de arte, não deve enclausurar-se num discurso elitista e esotérico, mas exercer uma função de ponte, de tradução (função mais tangível na crítica musical ou da escultura, dado o décalage dos

${ }^{34}$ A defesa da pluralidade irredutível das ordens do discurso ocupa - no caso vertente, o discurso poético e o discurso especulativo ou filosófico - os dois últimos capítulos de Metáfora Viva, de Paul Ricoeur, em que são defrontadas as teses de Heidegger e Derrida.

${ }^{35}$ Cf. Habermas, op. cit., pp. 182-185, com citaçóes de Paul de Man e Jonathan Culler. 
meios expressivos) do conteúdo experiencial da obra de arte para a linguagem «normal».

\section{4 - Poesia, Verdade E Beleza}

Retornando ao texto de Pessanha, dele se tira o alto conceito que Pessanha nutria relativamente à poesia: «um único intuito» deve presidir ao autêntico labor poético, o de «realizar, por meio da verdade, a beleza». De notar, além da carga volitiva do verbo «realizar», a enunciação da "beleza» como causa final. Invertida a ordem, "por meio da beleza, a verdade», teríamos a formulação mais categórica da possibilidade do conhecimento absoluto através da arte.

Com o sublinhar de uma mera expressão, "por meio da verdade, a beleza» (que pode muito bem ser apenas uma fórmula laudatória convencional da época), não se pretende tornar Pessanha num discípulo de Hegel ou de outros crentes em «absolutos» ${ }^{36}$.

Porém, se é verdade que, posta a tríade eu/texto/mundo, o Simbolismo ${ }^{37}$ privilegia, contra o Romantismo que flecte o texto para a instância pessoal (as implicaçóes entre o autor textual e o autor empírico tendem a ser particularmente estreitas) e contra o Realismo/ Parnasianismo, que inclina o texto para a res, a urdidura verbal por si mesma, daí não se segue que seja suprimido radicalmente o pendor referencial da poesia, embora com flutuaçóes que se desvendaráo. Este extremar dos pólos não significa que, todavia, o Romantismo (o "profundo», não o epidérmico, sobretudo o Romantismo alemão) prescinda de um realismo fundamental em termos ontológicos e literários. A teoria do génio e a redução do mundo à «minha» representação não

${ }^{36}$ A data deste artigo, 1910, reforça, a nosso ver, o seu relevo teórico e a luz que possa lançar sobre a concepção de poesia de Pessanha. Com efeito, parece que a partir da morte da mãe Pessanha cessa a criação poética, conhecendo-se, a partir dessa data apenas duas poesias, claramente de circunstância, «Em um retrato», «Rosas de Inverno» (cf. Barbara Spaggiari, «Notas da Introdução», in Camilo Pessanha, Clepsidra e outros poemas, Edição crítica organizada por Barbara Spaggiari, Porto, Lello Editores, p. 260, nota 35). Portanto, não é ousado conjecturar que, no decurso da primeira década novecentista, Pessanha tenha reflectido sobre a poesia que, mais uma vez, aparentemente, havia deixado de produdir.

37 Supóe-se, provisoriamente, que Simbolismo, nestas consideraçóes assaz esquemáticas, seja uma poética coerente, com unidade doutrinária, e igualmente o Romantismo e o Realismo. E que seja pacífica a inserção da poesia de Pessanha no Simbolismo. 
têm como arena um solipsismo insuperável, antes visam como escopo último revelar o ser profundo do mundo, as coisas como elas realmente são, em oposição à sua percepção vulgar, habitual: "A poesia é o autêntico real absoluto. Isto é o cerne da minha filosofia. Quanto mais poético, mais verdadeiro» ${ }^{38}$.

Àquela transparência bifronte, o Simbolismo significa uma aposta na espessura do tecido verbal, daí resultando um certo obscurecimento ou opacidade, mas não uma opacidade total de uma linguagem que se curvasse unicamente sobre si mesma. $\mathrm{O}$ Simbolismo quis ser uma arte difícil, como outrora o Barroco ${ }^{39}$, ainda que, nas palavras de Baudelaire, citando Edgar Poe, distinguindo a obscuridade da expressão da expressão do obscuro. Donde decorre que os pontos de indeterminação e lacunas, traços distintivos do discurso literário, segundo Ingarden, que tornam o texto literário um texto aberto à interpretação múltipla, sulcam largamente a poesia simbolista.

O poeta seria então, primordialmente, um "syntaxier», segundo Mallarmé, ou um «réunisseur d'images» (Claudel), um trabalhador do texto. Mas a imagem simbolista quer dizer símbolo analógico, não fechando a linguagem sobre si mesma, antes conferindo-lhe transitividade ad extra (passe-se o pleonasmo), embora por sugestão ou alusão, isto é, ambiguamente.

Com efeito, um dos eixos fundamentais da poética do Simbolismo foi a doutrina das correspondências, gizada por Baudelaire, em que tudo se assemelha a tudo, o macrocosmo e o microcosmo (o homem, que segundo uma antiga e bela ideia resume em si todo o universo, todas as suas ordens), náo de um modo evidente, mas hieroglífico, numa floresta de símbolos, em cujo rumor o poder de decifração do poeta ausculta o enigma metafísico do mundo.

Cruzam-se, transferem-se em alquimia verbal reinos distantes, o dos sons, o das cores, o das palavras, como pretendia o poema de Rimbaud «Voyelles» («A noir, E blanc, I rouge, O bleu, U vert:

${ }^{38}$ Novalis, pensamento escolhido como epígrafe da Colecção Poesia das Ediçóes Ática.

${ }^{39}$ Não trilharemos a larga senda exploratória das afinidades entre Barroco e Simbolismo. Basta notar que para a activação do processo de redescoberta e revalorização do Barroco por poetas como T. S. Eliot ou a geração espanhola de 27 muito contribuiram a poesia e a poética simbolistas, como assinala de passagem Luís Miguel Nava em "A propósito duma imagem de Pessanha», in Persona, 10, 1984, p. 36, nota 3 («não é casual o facto de ter sido na sequência deste movimento que o Barroco foi reabilitado»). 
voyelles,/ Je dirais quelque jour vos naissances latentes.») ${ }^{40}$.

Voltaremos a este ponto fundamental, o da referencialidade da poesia simbolista (e, posteriormente, da de Pessanha), distinguindo duas inflexóes que tendem a divergir: o pendor metafísico e a incoativa tendência para encarar o texto poético como auto-suficiente.

O propósito que sustenta esta dissertação é precisamente o de tentar deslindar que «eu» e que «mundo», ou as suas metamorfoses, camadas ou denegaçóes, é que comparecem na poesia de Pessanha, elegendo, sem paradoxo, o "sentimento» como fio condutor da detecção da sua dimensão gnoseológica.

Para o poeta, então, no artigo crítico de obra alheia, acima mencionado, a poesia seria, por suposto, a forma de conhecimento supremo ("por meio da verdade, a beleza»), inserindo-se assim numa das linhas de força da poética do Simbolismo em geral e numa funda corrente da cultura ocidental que vê na poesia a arte suprema e o supremo grau de conhecimento ${ }^{41}$.

Se o núcleo do presente trabalho é a dimensão cognoscitiva da poesia de Pessanha (a pergunta primacial consiste em determinar acerca de quê ou de quê é esta poesia conhecimento, pelos sentimentos dominantes que a impregnam), trilharemos

${ }^{40}$ Apud Fernando Guimarães, «Simbolismo: A Procura da Originalidade», in Simbolismo, Modernismo e Vanguardas, Lisboa, IMCM, 2004, p. 18. Deve notar-se que esta correspondência entre sons e cores náo é encarada por Rimbaud, esse "meteoro enlouquecido", na palavra de Mallarmé, como uma verificação de uma verdade científica dada à partida: "J'inventai la couleur des voyelles» - logo uma invenção, uma criação poética que não é, contudo, puro arbítrio, pois rasga as "naissances latentes», recolhendo o seu brotar nos vasos do verbo poético. Fere-se aqui a dialéctica que póe a poesia e o mundo numa co-operação originária: a poesia molda o mundo tanto como é moldada por ele ou a poesia obriga o mundo a mostrar as suas regióes ou fundos desconhecidos.

${ }^{41}$ Seria leviano sequer tentar uma síntese panorâmica da vexata quaestio do «lugar» e do valor da poesia na tradição ocidental desde os Gregos até aos simbolistas. É um truísmo constatar que o ideal da «religião da arte» encheu o século XIX. Notamos também que, para demonstrar a persistência e a resiliência desta valoração da poesia como forma, pelo menos, de «alta cultura", os autores da introdução, "Desaprender (com) a História», Osvaldo Manuel Silvestre e Pedro Serra, in Século de Ouro Antologia Crítica da Poesia Portuguesa do Século XX, detectam en passant, no conhecido livro de I.A. Richards, Practical Criticism. A Study of Literary Judgement, (1a edição, 1929), o pressuposto de que a Poesia encarnaria o valor supremo da cultura ocidental e que, por consequência, a leitura se guindaria no «espelho do status quo civilizacional de uma sociedade» (ibidem, p. 23). 
naturalmente as clareiras abertas pelas leituras simbolista e simbólica, termos quase redundantes, do poeta. Como não consideramos a biografia algo de excrescente a pôr de parte, chamaremos à colação um ou outro passo da epistolografia do poeta. Temos, em todo o caso, plena consciência de que a leitura a que procederemos é, inevitavelmente, uma leitura de leituras.

\section{5 - EM TORNO DE DOIS CONCEITOS PERIODOLÓGICOS, Decadentismo e Simbolismo.}

A repetição de uma fórmula consagrada não infirma, pela reiteração, a sua validade. Nem designar a poesia de Pessanha como simbolista equivale a arrumá-la numa prateleira ou amarrá-la a um ismo. Se a mudez pirrónica ou o sofisticado acto de ler e calar prevalecessem, ou fossem a conclusão lúcida depois de esgotadas todas as outras vias, não só ficariam professores e críticos condenados ao desemprego, como também os poetas inibidos do seu ofício.

É inescapável falar de Simbolismo quando se trata de Camilo Pessanha. Nenhum termo se impóe na tradição crítica por mera arbitrariedade. A explícita recusa do poeta em filiar-se em escolas ou movimentos literários pode ser usada como argumento para intentar interpretaçóes discordantes de um quadro teórico há muito consolidado, mas esta recusa de rótulos ocorre em muitos autores, na arte ou na filosofia. Por exemplo, Verlaine ria-se de decadentistas e simbolistas, ou naquele vasto conglomerado filosófico-literário conhecido por Existencialismo, apenas Sartre náo enjeitava o epíteto de existencialista, antes o promoveu (ao contrário de Jaspers, Heidegger, Marcel). A era do individualismo, também na arte, suscita a vocação artística sem Igreja, ou mais prosaicamente o temor de "cada poeta passar a ser epígono» ${ }^{42}$.

Assim, o termo que logrou impor-se, desalojando outros epítetos eventuais, foi na fortuna crítica do poeta o de simbolista ${ }^{43}$.

${ }^{42}$ Cf. Fernando Guimarães, "Introdução", in Simbolismo, Saudosismo e Modernismo, Antologia de Poesia Portuguesa, Vila Nova de Famalicão, Ed. Quasi, 2001, pp. 8, 9. Este «síndrome» é explicado pelo autor como um efeito, no contexto da poesia portuguesa novecentista, do "peso» do Modernismo de Pessoa e Almada que criou a propensão para que todo o poeta autêntico posterior se demarcasse relativamente «a um passado tão próximo que corria o risco de se tornar demasiado presente». O medo de ser epígono é uma modulação da «ansiedade da influência», teorizada por Harold Bloom, referida na página 9 .

${ }_{43}$ «O simbolismo português em estado puro e cristalino resume-se a 
Por exemplo, no estudo capital de Esther de Lemos, aflora outro termo, «impressionista» ${ }^{44}$, que contudo não vingou como o epíteto emblemático de Pessanha, como sucedeu com Cesário Verde. É, porém, uma possibilidade tentadora declarar à partida que toda a classificatória é enfadonha e livresca e que embaraça o encontro com a literatura viva. Que todo o grande escritor ultrapassa qualquer «ismo». É verdade que Camilo Pessanha nunca se auto-designou de simbolista. Mas não são poucos os escritores que também foram doutrinários. Como não aplicarlhes, então, os epítetos que eles próprios forjaram, em que eles se reconheceram? Esquece-se também que, o que poderia plasmar um acto de rebeliấo, se volveu num lugar comum: a recusa dos rótulos ou de os aplicar pode-se transformar num gesto convencional, num psitacismo, do tipo Marx nunca foi marxista, ou Bergson nunca foi ou se declarou bergsonista ... Este tipo de sobranceria, tributária da velha querela entre criadores e professores ou críticos (estes últimos, com as suas dissecaçôes e análises, secariam a linfa da grande arte... ao invés, «só o poeta entende de poesia», assevera António Barahona em "A Chave da Clepsydra» ${ }^{45}$ ), eiva, a nosso ver, consideraçóes como estas do autor imediatamente antes referido: «a história da literatura, com as suas prateleiras e escolas, só tem uma virtude: a de nos ensinar que os grandes poetas, em termos honestos e absolutos, não se ocupam em nenhuma prateleira, nem pertencem a nenhuma escola» ${ }^{46}$, ou "uma certa história da literatura é para desaprender ${ }^{47}$. Mais radicalmente do que Barahona, dizia Kafka que detestava tudo o que não fosse literatura, incluindo discussóes sobre literatura...

Retivemos numa das suas notas a referência a uma "provocação»: "On s'est évertué à juger le mouvement symboliste. Il n’a jamais

cerca de quarenta poesias reunidas na Clepsidra» (Óscar Lopes, Entre Fialho e Nemésio, Vol. I, Lisboa, INCM, 1987, p. 117); «(...) único verdadeiro simbolista da literatura portuguesa e, em absoluto, um dos maiores intérpretes do Simbolismo europeu» (Barbara Spaggiari, op. cit., p. 13), «um dos nossos mais puros simbolistas» (João Gaspar Simóes, "Estudo crítico", in Poesias, de Mário de Sá-Carneiro, Lisboa, Ed. Ática, 1991, p. 17).

44 Por exemplo, quando compara o lirismo marcadamente visual de Pessanha «ao impressionismo pictural» (Esther de Lemos, op. cit., Lisboa, Editorial Verbo, 1981, p. 63).

${ }^{45}$ In Clepsydra Poemas de Camilo Pessanha, Lisboa, Assírio \& Alvim, 2003, p. 137.

${ }^{46}$ Ibidem, p. 166.

${ }^{47}$ Ibidem, p. 168. 
existé» ${ }^{48}$. Tomada literalmente, a frase é um absurdo, dados os manifestos, a produção extensa de textos teóricos... ${ }^{49}$

Mas afinal do que se fala quando se fala de Simbolismo?

\section{1 - A eclosão gaulesa do Decadentismo e do Simbolismo}

A aproximação mais óbvia a essa corrente literária e artística, sob o ponto de vista histórico, é situar o epicentro do movimento em França e registar o seu alastramento pelos diversos países europeus, de Lisboa a Moscovo. Autores como Teixeira de Pascoaes ou Fernando Pessoa, ao demarcarem posteriormente as suas estéticas do Simbolismo, não deixaram de o ter como um fenómeno "francês». A sua recepção pelos círculos literários/ artísticos não-gauleses revestiu como é óbvio «nuances», termo que Verlaine então "canonizou», assaz diversas.

Porém, duas atitudes, menos antagónicas do que parecem à primeira vista, prevalecem em países de tão rica tradiçáo literária como Inglaterra e Alemanha: não precisamos para nada dos simbolistas franceses e/ ou nós somos já simbolistas. O Simbolismo francês foi entendido como estímulo ou como empréstimo, mais do que modelo a copiar ou transplantar. Estas modalidades de recepção atestam que os eflúvios literários das margens do Sena devem ser vistos como emanaçóes de uma torrente mais vasta.

Como o Classicismo, o Barroco ou o Romantismo, o Simbolismo, embora de duração mais curta devido à aceleração histórica, alcança uma dimensão europeia, dando corpo a um espírito ou, menos incorporeamente, a uma situação e um projecto literário/artístico comuns, sendo talvez o último «ismo» a alcançar essa escala.

Ora, na sua génese, o Simbolismo gaulês reveste um carácter cosmopolita: «tenir compte de l'apport étranger quand il était, comme celui des grands Russes e des Scandinaves, révélateur, tels étaient les points communs» ${ }^{50}$.

${ }^{48}$ Camille Mauclair, Servitude e Grandeur littéraires, 1922, p. 47, cit. por Barahona, op. cit., p. 183, nota 77.

49 Sobre a tensão entre as generalizaçôes estilístico-periodológicas e a individualidade irredutível do texto ou da obra, vide José Carlos Seabra Pereira, O Neo-romantismo na Poesia Portuguesa: 1900-1925, Tese de Doutoramento apresentado à F.L.U.C., Coimbra, 1999, pp. 9-13.

50 Gustave Kahn, apud José Carlos Seabra Pereira, Decadentismo e Simbolismo na Poesia Portuguesa, Dissertação de Licenciatura em Filologia Românica, Coimbra, 1972, p. 7, nota 3. 
Alguns dos seus representantes são de origem estrangeira, como Moréas ou Stuart Merrill, e é notória a vertente belga do movimento, na qual se destacou Verhaeren. Mas acima de tudo teríamos os pontos de contacto com os Romantismos inglês e alemão, que constituiriam o solo, segundo Octavio Paz, onde entroncaria o Simbolismo e de cuja arborescência penderiam as diversas vanguardas novecentistas ${ }^{51}$.

Deste modo, a difusão do Simbolismo francês encontrava já activos, nas grandes literaturas inglesa e alemã, veios "autóctones» para se misturar e metamorfosear ${ }^{52}$, o que explica as modalidades da sua recepção que explicitámos acima: a música simbolista não soava estranha a ouvidos ingleses e, sobretudo, alemães. Diremos alguma coisa sobre as raízes românticas do Simbolismo, quando abordarmos a pertinência das categorias do "coração» e do «sentimento» na hermenêutica da poesia de Pessanha. Em Portugal, a condição francófila da cultura portuguesa de então torna-a particularmente permeável às novidades literárias parisienses.

Aplicando o conceito de geração literária, a geração dos simbolistas francesa ou de língua francesa propriamente dita, a que ergue o facho da revoluçáo simbolista, nasce entre 1855 e 1865 e compreende nomes como Émile Verhaeren, Georges Rodenbach, Jean Lorrain, Jean Moréas, Rémy de Gourmont, Albert Samain, Péladan, Kahn, Laforgue, Charles Morice, Félix Fénéon, Saint-Pol-Roux, Van Lerberghe, Le Roy, Maeterlink, Ghil, Barrès, Paul Adam, Marie Krysinska, Pierre Quillard, Henri de Régnier, Francis Vielé-Griffin... As suas figuras de referência são Baudelaire, o grande precursor, Verlaine e Mallarmé, quadragenários em meados de 1880, a que se devem acrescentar Bourget, Bloy e, sobretudo Huysmans, nascidos por volta de 1850 e que haviam produzido obras de vulto.

Todo o movimento literário constitui uma reacção, uma tomada de posiçáo contra o movimento dominante. Mas, pelo

${ }^{51}$ Apud Guimarães, «Introdução: Simbolismo e Decadentismo», in Poética do Simbolismo em Portugal, Lisboa, INCM, 1990, p. 9. Este autor ressalva que esta perspectiva náo se aplica plenamente à poesia portuguesa que teria de esperar por Antero de Quental ou Teixeira de Pascoaes para conhecer um Romantismo superior ou profundo.

52 É atribuído à figura de Heine o papel de intermediário entre o Romantismo alemão e o Simbolismo francês. Cf. José Carlos Seabra Pereira, Decadentismo e Simbolismo na Poesia Portuguesa, Coimbra, Centro de Estudos Românicos, 1975 , p. 65, nota 17. 
menos desde a dialéctica hegeliana, é comum constatar que o pólo antitético ou o momento da negação incorpora elementos da figura a que se opóe. Segundo Hegel, todo o conflito é também especular.

Assim, na sua demarcação relativamente ao Naturalismo e ao Parnasianismo (e também do Romantismo - Pas de Victor Hugo»e suas derivas epigonais), o Simbolismo reflecte, modificados, alguns dos elementos dessas estéticas.

Para um apanhado do lado negativo do Simbolismo, servirá a citação do trecho inteiro de Gustave Khan, de que isolámos, anteriormente, um aspecto: "L'union des Symbolistes, autre un indéniable amour de l'art, et une tendresse commune pour les méconnus de l'heure précédent, était surtout faite par un ensemble de négations des habitudes antérieures. Se refuser à l'anecdote lyrique et romanesque, se refuser à écrire à ce va-comme-je-tepousse, sous le prétexte d'appropriation à l'ignorance du lecteur, rejeter l'art fermé des Parnassiens, le culte d'Hugo poussé au fétichisme, protester contre la platitude des petits naturalistes, retirer le roman du commérage et du document trop facile, renoncer à de petites analyses pour tenter des grandes synthèses, tenir compte de l'apport étranger quand il était, comme celui das grands Russes ou des Scandinaves, révélateur, tels étaient les points communs» ${ }^{53}$.

Relativamente ao Parnasianismo, entendendo por este todo o discipulado de Leconte de Lisle que gravitou em torno das três ediçôes do Parnasse, é nítida a zona de intersecção entre os dois movimentos: a teoria da arte pela arte, o apreço comum pelo labor poético, a aversão pelas efusóes sentimentais românticas ...

Mas antes de apontar as linhas mestras do sistema simbolista, convém dizer algo sobre o Decadentismo.

Com efeito, no universo literário francês, o Simbolismo é precedido peloDecadentismo, preparaçãoauroraldaquele, segundo alguns estudiosos. Contudo, o Decadentismo não se esgota numa função propedêutica, pois sobrepóe-se à eclosão do Simbolismo, mantendo tangências e afinidades. A distinção clara dos dois conceitos estilístico-periodológicos não se tornou uma evidência consensual. Por exemplo, no seu ensaio prefacial a Clepsidra,

${ }^{53}$ Apud José Carlos Seabra Pereira, Decadentismo e Simbolismo na Poesia Portuguesa, Dissertação de Licenciatura em Filologia Românica, Coimbra, 1972 , p. 7 , nota 3. 
António Quadros utiliza a díade decadentista-simbolista ${ }^{54}$, como modulaçôes do mesmo coro.

$\mathrm{Na}$ verdade, quando o termo "Simbolismo» e cognatos se difundem crescentemente na década de 1880 , não se seguiu um eclipse da designação "decadentismo». Basta notar que justamente em 1886, o ano da publicação do manifesto simbolista por Jean Moréas, no Fígaro, são publicados um jornal e uma revista com os títulos, respectivamente de Le Décadent, dirigido por Anatole Baju, e La Décadence, dirigida por Émile-Georges Raymond. Aliás, o mesmo manifesto de Moréas consagra o termo Simbolismo como o mais adequado para designar o movimento decadentista ${ }^{55}$. Portanto, o que ocorre é que a maior parte dos autores decadentistas transita sem qualquer gesto de ruptura para o conjunto simbolista.

Esse trânsito tranquilo é considerado, reveladoramente, como típico pela célebre paródia literária Les Déliquescences, 1885, cujo prefaciador, da $2^{\mathrm{a}}$ edição, G. Vicaire, declarara numa carta a François Coppée: «Je viens d'achever cette préface. Elle passe en revue toute la vie du poète déliquescent et marque ses différentes étapes vers le symbolisme» ${ }^{56}$.

54 «Talvez nunca entre nós, como em Camilo Pessanha, tenham sido tão coincidentes os princípios de uma escola (a do simbolismo decadentista) com a realidade biográfica de uma existência humana.» (António Quadros, "Introdução biográfica e crítica», in Clepsidra e poemas dispersos, p. 49). E considera a Tentativa de um Ensaio sobre a Decadência, de Luís de Montalvor, publicado na antecâmara de Centauro, o manifesto tardio do Decadentismo (cf. ibidem, pp. 25,26).

${ }^{55}$ Estas sobreposições justificam a "confusão que durante muito tempo se manteve entreSimbolismo edecadência», nas palavras de Guy Michaud, segundo o qual essa indistinção não atentava nas diferenças irredutíveis do Simbolismo: a teoria da sugestão acarreta que a experiência poética é expressáo criadora, operando na e pela linguagem, ultrapassando o factor subjectivo-individual, a psicofania romântica, ainda dominante no Decadentismo (apud Rubim, Experiência da Alucinação Camilo Pessanha e a Questão da Poesia, Lisboa, Ed. Caminho, 1993, p. 24). Mas essa confusão é assinalada a posteriori e não tanto no momento da eclosão desses ismos. Também em Portugal o termo decadente foi aceite sem reservas, como o demonstra a contracapa do livro Azul (Coimbra, 1890) de Oliveira-Soares, onde se filia esta obra e Oaristos de Eugénio de Castro, o introdutor "oficial» do Simbolismo em solo luso, como a História da Literatura regista, na «Literatura Decadente» (cf. Guimarães, Poética do Simbolismo em Portugal, p. 13, nota 11).

${ }^{56}$ Apud Seabra Pereira, Decadentismo e Simbolismo na Poesia Portuguesa, Coimbra, Centro de Estudos Românicos, 1975, p. 60. 
Simples mutação terminológica, motivada pelo carácter pejorativo do termo decadência, a descartar? Processo gradual de maturação poética e teórica?

A marca distintiva do Simbolismo francês relativamente ao movimento predecessor parece ser uma profusa e robusta reflexão crítica sobre a arte, sobretudo a natureza da poesia ${ }^{57}$. Traços distintivos do Simbolismo como a aliança da poesia com a música e a teoria da arte pela arte estáo já formulados na estética decadentista. O Simbolismo desenvolve e consolida estas coordenadas, reunindo-as em torno da noção axial de símbolo, atingindo um maior grau de sistematicidade teórica, através da produção de poéticas e estéticas, alcançando um patamar afirmativo e teórico que o Decadentismo não detinha. Os principais textos teóricos foram o Traité du verbe de René Ghil, o Avant dire de Mallarmé a esta obra, e outros textos capitais do mesmo autor, os artigos de Wyzewa, o Manifesto de Moréas, as obras teorético-críticas de Charles Morice, as respostas à Enquête sur l'evolution littéraire efectuada por Jules Huret, as asserçôes muito respeitadas de Albert Mockel, etc ${ }^{58}$.

No caso português, contudo, esta linha de demarcação é à partida duvidosa, porque a produção teórico-prática de poetas e críticos é escassa, quando comparada com aquela produzida em França ${ }^{59}$. No juízo de Seabra Pereira, se «no fim-de-século» lusíada «vários escritores se elevam à criação de textos simbolistas», esta

57 «As posições decadentistas sobre a criação poética ou sobre a natureza e alcance da literatura, em particular da lírica, não são objecto de uma teorização literária sistemática. Quanto à criação poética, não surge mesmo qualquer pronunciamento ...", Seabra Pereira, op. cit., p. 47. O último lustro do século XIX foi fértil na produção de «ismos» literários, efervescência que se prolongará nas vanguardas do século XX. Num artigo do jornal Le Décadent (1886), Albert Aurier registava "le suggestivisme, le symbolisme, l'harmonisme, le quintessencisme, etc», pugnando pela sua fórmula, «le Sensationnisme» (apud ibidem, p. 14), termo com que Pessoa identificará a base filosófica da sua poética.

O efeito revelador que a composição paródica, através do traço grosso da caricatura, produz sobre as poses, os tiques e o receituário do Decadentismo e Simbolismo portugueses é relevado por Guimarães em «Entre a expressão paródica e a poética da alteridade», in Poética do Simbolismo em Portugal, pp. 55-68.

${ }^{58}$ Cf. Seabra Pereira, op. cit., p. 65.

59 «(...) não há em Portugal nada que se pareça com a abundante produção teórica e crítica dos simbolistas de origem francesa", Rubim, Experiência da Alucinação Camilo Pessanha e a Questão da Poesia, p. 57. 
é «desacompanhada de correspondente elaboração teorética»" ${ }^{60}$.

$\mathrm{O}$ Decadentismo coloca-se ab initio como movimento à rebours, altivamente marginal. A imagem do escritor decadentista, no início da década de 1880 , é a do poète maudit, e a poesia, como se dirá da revolução, devora os seus próprios filhos. $\mathrm{O}$ sinal de eleição é também estigma de maldição. Esta retórica pode traduzir mais que uma pose. De facto, as suas grandes figuras de referência, Verlaine e Mallarmé, são excluídas em 1876 do Parnasse Contemporain, órgão do Parnasianismo. A marca de perseguição aferroada pela literatura «oficial» torna-os reverenciáveis pelos clubs e clans poétiques dos cabarets parisienses. A sua feição iconoclasta ${ }^{61}$ transparece nos seus nomes: fumistes, zutistes, hydropates, hirsutes...Contra quê se revoltavam os novos poetas? Antes de abordarmos as querelas de escolas, há que referir a palavra-chave - decadência - a crise civilizacional finissecular.

O sentimento difuso de decadência civilizacional, lato sensu, e das artes em particular não deixa de ser notado por Camilo Pessanha no seu principal texto crítico, já citado, quando constata que "para grande número de críticos, a actual e contestável decadência das artes é irreparável», concordando em considerar "por enquanto inigualáveis» as "obras-primas da antiguidade». Tratou-se de um fenómeno de proporçôes europeias, embora com maior acuidade nos países do sul da Europa. No entanto, o annus terribilis de 1870 em França não basta para explicar esse estado de depressão espiritual pois este estendeu-se à Alemanha vitoriosa, a qual se tornará na maior potência económica europeia a partir de 1887 ou à Inglaterra, em cujo Império vitoriano o sol não se punha.

Este mal-estar da civilização é explicável pela exasperação de idealistas no seio de uma sociedade materialista, por uma desforra do espírito, ou do mistério ou do irracional perante a prevalência do espírito das Luzes e do Cientificismo/ Positivismo? Laforgue inverte a marcha do "progresso" quando lança panfletariamente: "Aux armes, citoyens/ Il n'y a pas de RAISON ${ }^{62}$.

${ }^{60}$ Seabra Pereira, op. cit., p. 457, nota 7.

${ }^{61}$ Se, segundo Blake, Milton tomava o partido do diabo sem o saber, já alguns poetas decadentistas se colocavam sob o seu patrocínio deliberadamente, ora querendo casar o céu com a terra, a exemplo de Blake (nomeadamente, revendo-se no catolicismo sensual atribuído ao reinado de Henrique III), ora revendo-se nesse grande banido, na suas tristeza e rebelião incuráveis, na esteira de Byron, entre outros.

${ }^{62}$ Apud Seabra Pereira, op. cit., p. 48. Observando que Bacon, Copérnico, 
Um panorama breve das correntes filosóficas de inclinação pessimista não faz parte do escopo deste estudo. Porém, um nome invariavelmente aparece na abordagem deste ponto, Schopenhauer, cuja influência por via, designadamente, de Eduard von Hartmann, é reconhecível na figura intelectual mais respeitada e influente nos círculos intelectuais da segunda metade do século XIX, Antero de Quental. Como este, Camilo Pessanha náo rejeita as contribuiçóes da ciência, ou o seu valor progressivo, mas declara uma zona do espírito humano intangível ao bisturi da ciência: o incognoscível.

As referências ao filósofo alemão em estudiosos como Barbara Spaggiari, Álvaro Cardoso Gomes, Paulo Franchetti e Christine Pâris-Montech («L'ombre portée de Schopenhauer») justificam que se faça um excurso acerca do seu pensamento e se abordem eventuais pontos de contacto com a poesia de Pessanha

\section{2 - Excurso: Schopenhauer e Pessanha}

Para os estudiosos deste filósofo e do seu legado, é unânime a conclusão de que a sua influência, se relativamente marginal na esfera da produção especificamente filosófica, foi considerável em muitos círculos artísticos, a que náo terá sido alheio o seu estilo de escrita, chão e claro, desembaraçado de terminologia abstrusa. A dualidade kantiana, fenómeno/ númeno, é rebaptizada por Schopenhauer como representação/ vontade. A ciência não dispóe de acesso à realidade íntima do mundo, confinada ao plano da representação, regida pelo princípio da razão suficiente.

A chave de acesso ao para lá da representação, domínio da ciência, está dentro de nós, mas o analogon não é o intelecto ou a razão, que é para o homem o que a crosta é para a terra, mas a vontade, o ímpeto de viver, cuja manifestação mais poderosa e reveladora é o instinto de reprodução.

Kepler e Newton foram influenciados pela "hermética», não se podendo separar Galileu e Paracelso com a nitidez que a historiografia positivista afirmava, Umberto Eco (op. cit., pp. 51, 52) refere o paradoxo de ter o modelo hermético contribuído para o advento do seu novo adversário (na Idade Média era o «racionalismo» da escolástica), o racionalismo científico. Então, o irracionalismo hermético anicha-se em poetas e filósofos, nomeadamente, acrescentamos nós, em autores que se costumam agrupar na constelaçáo simbolista. Sobre a influência do esoterismo (sob a rubrica do qual, por comodidade, se podem abranger espiritismo, teosofia, cabalismo...) no Simbolismo, vide Seabra Pereira, op. cit., p. 67, notas 19, 20. 
A Vontade, com maiúscula, é uma potência cega, que não segura qualquer balança. A satisfação do desejo, de qualquer desejo, é como uma esmola que se dá a um mendigo para ele sobreviver durante um dia, regressando logo depois à indigência habitual. $\mathrm{O}$ desejo humano, multiforme, tem como o gouffre baudelairiano a sede de Tântalo. Mais que um autor adjectivou a concepção do desejo de Pessanha como schopenhaueriano ${ }^{63}$. Schopenhauer podia perfeitamente subscrever frases como as que se encontram na carta que Pessanha escreve a José Benedito Pessanha, em que esboça a tentativa de elaboraçáo de um livro, dividido em duas séries, uma de prosa, outra de verso: "a luta pela realização do prazer» abriga em si "a certeza de lutar por uma aspiraçáo falsa», pois «o prazer, não tendo realidade sua, era o aniquilamento do desejo, de forma que esta luta representaria ansiar pela morte», "cada desejo constitui uma dívida da natureza para quem o sente: a morte é a cedência das dívidas antigas, para evitar que ela volte a contrair novas dívidas ${ }^{64}$.

Sobre este pano de fundo irrefragavelmente pessimista, que papel é atribuído à arte, à experiência do belo, que é idêntica em Schopenhauer, seja a sua fonte a natureza ou a obra de arte? A arte, sobretudo a música, e a experiência que proporciona são vistas como sedativos, paragens momentâneas da roda de Íxion da vida humana, em que o desejo cessa para dar lugar à contemplação.

Contudo, a libertação radical da vontade de viver cujo único salário é o sofrimento (ou o tédio) é operada pelo ascetismo religioso, não só hindu ou búdico, mas também cristão. Não foi este último ponto do sistema de Schopenhauer o mais influente (embora não seja despiciendo o papel do filósofo alemão no movimento de «descoberta» das filosofias e religióes orientais), mas a sua visão do mundo como mal, como sofrimento inextinguível, a sua teoria do génio e a valorização da arte, em especial, como se disse, da música, como escape, alívio e contemplação.

Ora, a visão do mundo como mal tinge com as cores mais tenebrosas o julgamento de Pessanha sobre a civilização chinesa. No prefácio ao livro "Esboço Crítico da Civilização Chinesa», desfila um estendal de inúmeros horrores: "A disformidade, a monstruosidade, o raquitismo, o nanismo, o cretinismo... A tuberculose, a sífilis, o tebaísmo, a histeria, a epilepsia, a coreia, a 52.

${ }^{63}$ Por exemplo, Paulo Franchetti, O Essencial sobre Camilo Pessanha, p. 51,

${ }^{64}$ Ibidem, pp. 52, 53. 
lepra, asarna... A prostituição, o deboche, a pederastia, o sadismo... A preguiça, o parasitismo, a mendicidade, a vagabundagem, o jogo, o lenocínio, a escravatura... A fraude, a chantagem, o furto, o roubo, o banditismo, a pirataria, o cativeiro... E de tudo isto todos os dias - uma exibição permanente de tudo quanto se possa imaginar de mais lastimoso e de mais extravagantemente sinistro -, montão de lixo constituído pelos mais asquerosos detritos, caudal de esgoto arrastando as mais irreconhecíveis escórias humanas. Ignorância, boçalidade, superstição, deslealdade, covardia, avareza, sensualidade, crueldade, desfaçatez, cinismo, atonia moral ${ }^{65}$.

Numa palavra, é dissecada, revolvida a flora do mal desse «inferno amarelo», expressão que respiga de Pierre Loti. Esta visão darwinista e dantesca da sociedade, da humanidade, não já chinesas, mas universais, é transportada para a sua poesia, nomeadamente em "Porque o melhor, enfim»: «rixas, tumultos, lutas», «brigas», «mortes duras», «a torva ralé» que «irrompe, tumultua,/ Se estorce, vocifera,/ Selvagem nos conflitos,/ Com ímpetos de fera»», "roubos, assassinatos!», «brutos pugilatos»...

Também a irredutibilidade da Vontade, o inestancável e cego impulso vital, que persevera, indiferente às delicadezas e escrúpulos da consciência moral ou da prudência racional, é tematizada no poema "Vida», em que a potência dos elementos da chuva e do fogo é declarada indomável: é inútil todo o esforço para repor uma ordem, um equilíbrio ou uma medida, isto é, no contexto, calcar as pletóricas liliáceas e apagar o fogo que anda pela serra, pois «Se aqui o pisam, rebenta além» e, como que respondendo ao protesto da consciência humanista ( -E se arde tudo?»), soa a réplica fatalista da voz do poeta: «- Isso que tem!/ Deitam-lhe fogo, é para arder...».

Mas este pessimismo amargo não pode ser ostensivamente imputado à influência de Schopenhauer. Como ressalva o poeta Henrique de Vasconcelos a propósito da influência de Antero de Quental sobre a espiritualidade e o pessimismo dos novistas (Antero, leitor de Eduard von Hartmann, por onde se infiltrou o pensamento de Schopenhauer), estas tendências podem ter fontes variadas («e o pessimismo que abre o lábaro de vez em quando, em quase todas as suas obras. Mas isso mesmo poderia ter vindo

${ }^{65}$ Camilo Pessanha, Contos, Crónicas, Cartas escolhidas e Textos de temática chinesa, Organização e Notas de António Quadros, Lisboa, Publicações Europa-América, 1988, p. 122. 
de Baudelaire, Moréas, Nietzsche, Schopenhaeur...»"$\left.{ }^{6}\right)$. Porém, no estudo que Carlos de Mesquita inclui na revista Os Novos de um poeta e pintor, Jerónimo Freire, figura de ficção que pode ser lida como a tentativa de fixar um tipo, o do artista decadente, sublinha-se o influxo de Schopenhauer ${ }^{67}$ na sua evolução para um pessimismo radical que o coloca «No píncaro da renúncia» e o leva a desenvolver um misticismo de coloraçáo litúrgica e mergulhar nas "correspondências» e "comunicação pelos espíritos», sob a égide de Ruysbroeck e de Swedenborg ${ }^{68}$.

Podem-se, também, descobrir tangências entre a concepção de arte do autor de $O$ Mundo como vontade e representação e ideias que Pessanha tenha expresso sobre a natureza e função da arte?

A resposta é afirmativa. Ligada ao referido projecto de uma obra, que ilustraria a teoria negativista do desejo, Pessanha parece ter concebido a arte como renúncia ao desejo e ao gozo dos sentidos. É o que Paulo Franchetti deduz de dois fragmentos do texto Solidóes: num deles, intitulado Ofertório, lê-se: "O primeiro momento da minha alma, na plenitude da graça, quando assumiu a divina eucaristia deste livro./ quem sabe se não tornarei a comungar, tão perfeitamente, no completo recolhimento de todos os meus sentidos»e, no Monitório, dirigido ao leitor: «Embebei os vossos lenços nas águas vivas da torrente milagrosa. Lavai os olhos e logo as névoas vos cairão e podereis ler neste livro de piedade. Não vos esqueçais, porém, de que é indispensável todo o vosso zelo e que as vossas almas estejam isentas de toda a culpa pelo arrependimento do coração ${ }^{69}$. Evidentemente, é legítimo ver nesta linguagem cerradamente religiosa, mas deslocada para o campo da arte, uma amostra a mais da ideia de não poucos simbolistas da religião da arte, ou desta como substituição daquela. Queria-se abandonar o templo, mas conservar a sua aura... Se esta perspectiva, na vida do autor,

${ }^{66}$ Apud Guimarães, Poética do Simbolismo em Portugal, p. 10.

${ }^{67} \mathrm{O}$ nome e as tintas negras do pensamento de Schopenhauer eram então difusas nos ambientes cultos em Portugal, como o atesta, também, a menção do filósofo por Gomes Leal, nomeadamente, quando imputa à influência do ácido dissolvente das crenças tradicionais da filosofia de Schopenhauer o cepticismo de Fábio em $O$ Anticristo: «Tu não eras assim. Tens lido Baudelaire, Schopenhauer, talvez», cit. in Vitorino Nemésio, Quase que os vi viver, Lisboa, Bertrand, 1985, p. 265. Ou quando faz a figura feminina de Mulher de luto expressar um catarismo desesperado, recorrendo a "frases táo feras/ de Schopenhauer», apud Seabra Pereira, op. cit., p. 263.

${ }^{68}$ Apud Pereira, op. cit., p. 208.

${ }^{69}$ Apud Franchetti, op. cit., pp. 55, 56. 
foi apenas temporária, persistiu, contudo, o léxico religioso na Clepsidra, como foi notado por Barbara Spaggiari ${ }^{70}$.

Também para a ideia de Schopenhauer da arte como sedativo intermitente para o tormento de viver se pode encontrar um paralelo nesta observaçáo de Pessanha, contida numa carta a Carlos Amaro: «Delicioso e efémero efeito de luz, tão agradável para repouso dos olhos e da melancolia. Quem fosse capaz de o fixar em dois versos transparentes!...» $»^{71}$.

Insistimos que estes pontos de contacto relevados não significam necessariamente influência directa de um autor sobre outro. A este propósito, sobre imagens semelhantes que aparecem em poetas diversos, mas que não resultam de um jogo de influências, Luís Miguel Nava tem uma comparação muito schopenhaueriana: "Como pessoas que tivessem contraído a mesma doença - ou dela apresentassem idênticos sintomas - sem que entre elas haja

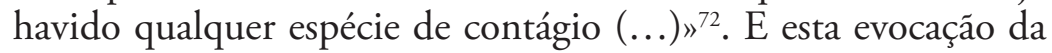
«doença» reconduz-nos ao irracionalismo da «décadence».

\section{3 - A volúpia da decadência e as palavras-chave do Simbolismo}

Uma simples mirada sobre certa temática decadentista, a exibição do desequilíbrio psiconervoso, a sexualidade doentia, etc, mostra o quão franqueado, pela agitação instintual que nela pulsa, estava o caminho para a constituição da psicanálise freudiana. Os dadaísmos e os surrealismos poderáo ser vistos como aceleraçôes num plano inclinado dos espasmos «décadents», daquilo que Bataille resumirá no termo «heterólogo» ${ }^{73}$. Aliás, o termo «décadents» é, em parte, a assunção de um labéu lançado sobre os novos poetas pelos seus críticos. Chegou a vir a lume uma revista de duraçáo breve, Le fou, 1883, cujo título toma como estandarte um vitupério. $\mathrm{O}$ termo recorda as vicissitudes vividas, mais tarde, pelo grupo do Orfeu, cuja blague lhes deu o equívoco prazer de serem apontados pelas ruas de Lisboa como candidatos a Rilhafoles. Os fautores da ciência psiquiátrica de

${ }^{70}$ Barbara Spaggiari, O Simbolismo na Obra de Camilo Pessanha, Lisboa, ICLP, 1982, p. 117.

${ }^{71}$ Pessanha, Contos, Crónicas, Cartas escolhidas..., p. 96.

${ }^{72}$ Luís Miguel Nava, «A propósito duma imagem de Pessanha», in Persona, 10, 1984, p. 34.

${ }^{73}$ No estudo da genealogia do Decadentismo, Mário Praz identifica o Romantismo negro como o subsolo destes motivos e temáticas «anormais». Cf. Guimarães, Poética do Simbolismo em Portugal, p. 12, nota 9. 
então, de cunho positivista, com realce para Max Nordau ${ }^{74}$, não deixam de visar essa literatura degenerada em nome da saúde e do progresso.

A consideração de poetas e poesias como "casos clínicos» conduz àquele movimento literário que pretendeu realizar uma literatura científica, justamente recortando como objecto as «patologias» sociais, com intuitos reformistas, o Naturalismo. Um ponto de sutura e de ruptura entre os dois movimentos pode ser encontrado em Huysmans. $\mathrm{O}$ autor de $\grave{A}$ rebours é um discípulo de Zola, do círculo de Médan. Mas enquanto teoricamente as patologias sociais escalpelizadas pelo romance naturalista serviriam um intuito de denúncia ou, como já se dizia, de crítica social, para o poeta decadentista são motivo de volúpia, de sinal de distinção aristocrática, acesso a estados de alma inacessíveis ao vulgo, incensos do culto do eu. La part maudite torna-se um campo de exploração do Absoluto, às avessas. Nas enfáticas palavras de Luís de Montalvor: «Ser-se decadente é ser-se doente espiritualmente, é ser-se superior! $\gg^{75}$.

É Baudelaire a grande figura de transição desta deriva de uma repulsa, por vezes assaz ambígua, pela decadência para a sua assunção desassombrada como fonte de inspiração estética e como estilo existencial. A doença, o pecado, o mal, os paraísos artificiais, o absinto, o culto do artificial, o dandismo...Mas há um ponto em que Baudelaire náo pode ser considerado um esteticista puro: não elide a distinção entre o Bem e o $\mathrm{Mal}$, não a julga inútil para a arte. Afinal, ficou famoso por ter dito que o grande truque de Satá é fazer acreditar ao homem que não existe.

Portanto, o literato decadentista não acredita que pode mudar o mundo, ou antes, defende o princípio da arte pela arte. Não julga o poeta fadado para uma missão civilizacional, de guia dos povos, de sacerdos magnus da revolução, à Victor Hugo. Ou para a de superior repórter da sociedade moderna em obras despojadas de marcas de subjectividade, à Zola.

A figura de Des Esseintes é paradigmática a este respeito. Como Cândido, desiludido com o mundo, quer passar os dias a

${ }^{74}$ Autor cuja obra, La Dégénérescence, terá tido um papel decisivo para a descolagem de Pessoa do Simbolismo: "Absolutamente subjectivo é o "simbolismo»; daí o seu desequilíbrio, daí o seu carácter degenerativo, há muito notado por Nordau» (F. Pessoa, A nova poesia portuguesa, Lisboa, 1944, p. 61, cit. por Barbara Spaggiari, «Pessanha e Pessoa: alle origine del simbolismo di Pessoa», in Persona, 10, 1984, p. 8, nota 4).

${ }^{75}$ Cit. por Quadros, Introdução..., p. 49. 
cultivar o seu jardim, ou melhor, isolar-se numa tebaida refinada de sensaçóes raras: rodeia-se de perfumes raros, jóias inusitadas, e sobretudo de arte e literatura. Reside aqui um dos grandes esteios da intensa originalidade procurada: poderiam ser suas as palavras do prefácio de Oaristos, a literatura como «silva esotérica para os raros apenas».

E é como leitor ideal ${ }^{76}$ que Mallarmé figura Des Esseintes, redigindo uma resposta às meditaçóes da personagem do romance sobre a sua própria obra. Bem interessante este comércio entre um poeta vivo e um personagem de romance: para muitos sonhadores letrados, Hamlet é mais real do que o vizinho do lado.

Uma frase-chave para a compreensão do Simbolismo é a de Mallarmé: "Nommer un objet, c'est supprimer trois quarts de la jouissance du poème qui est faite de deviner peu à peu: le suggérer, voilà le rêve» ${ }^{77}$. A especificidade da linguagem poética está na potência de sugestáo a que se opóe o acto de nomear, como outros oporáo a expressáo ( «La suggestion peut ce que ne pourrait l'expression ${ }^{78}$ ).

«Nomear», «expressar», «representar»...seriam domínios da prosa, da linguagem náo poética (na qual se poderia incluir a quotidiana e a científica). O discursivismo da linguagem comum ou lógica é para ser abolido ou suplantado. $\mathrm{O}$ objecto do discurso poético esbate-se, não interessa a linha ou o volume como no Parnasianismo, mas o indeciso, o vago, o matiz. A poesia escolhe o seu analogon na música, e o labor criativo incidirá na dimensão fónico-musical da linguagem.

${ }^{76}$ Figura definida por Joyce, em Finnegans Wake, foi desenvolvida por Umberto Eco sob a designação de leitor-modelo (cf. Eco, op. cit., p. 25). Se admitirmos a verdade da proposiçáo que estabelece que todos os textos prevêem, explícita ou implicitamente, pela natureza comunicacional do texto enquanto tal, um leitor modelo, poderíamos perguntar que leitor modelo o Simbolismo em geral postulou e qual a margem da sua iniciativa ou liberdade interpretativa...

${ }_{77}$ É este esbater de contornos da significação simbolista que permite que Óscar Lopes classifique justamente de «simbolista» o sentimento amoroso expresso em «Não sei se isto é amor» [Interrogação»] («um amor realmente simbolista, no sentido de que não sabe qual o seu objecto real», Óscar Lopes, "Camilo Pessanha», in Entre Fialho e Nemésio, Vol. I, p. 119). Nesta linha, o autor nota no soneto "Foi um dia de inúteis agonias» que o sintagma «um dia impressível» é lançado sem causa, «sem que se saiba ao certo de quê ou porquê», ibidem, p. 122.

${ }^{78}$ Ch. Morice, apud Seabra Pereira, op. cit., p. 77, nota 46. Mas este autor confere um «objecto» à sugestão: «La Suggestion est le langage des correspondences et des affinités de l'âme et de la nature». 
Daí que um dos herdeiros máximos do Simbolismo, Valéry, tenha declarado, redutoramente, "Ce qui fut baptisé le Symbolisme, se résume très simplement dans l'intention commune à plusieurs familles de poètes (d'ailleurs ennemies entre elles) de reprendre à la Musique leur bien ${ }^{79}$. Trata-se de transferir todo um reino: o reino da música para o reino da poesia.

Sugestão, poesia-música e ...símbolo: «on fait du symbole la condition essentielle de l'art ${ }^{80}$. Eis a tríade das palavras-ordem da estética simbolista.

As definições de símbolo nas poéticas simbolistas não são concordes, como seria de esperar. Mas podem-se salientar dois ou três traços comuns: o símbolo «simbolista» enquanto expressão indirecta do significado distingue-se, nomeadamente, da congénere alegoria, pela menor decifrabilidade, pelo seu carácter náo conceptista. Nas palavras de Albert Mockel, a alegoria e o símbolo fundam-se na analogia, mas na primeira «a analogia é artificial e extrínseca», enquanto que no símbolo "a analogia aparece natural e intrínseca $»^{81}$. Diferencia-se também do símbolo directamente ou facilmente reconhecível, do tipo: a pomba é o símbolo da paz, a cruz, do cristianismo, o ceptro e a coroa, da realeza.

No enunciado simbólico da poética simbolista há algo que o torna opaco, que impede o acesso directo à coisa significada. Possui um valor intrínseco, irradiando em vários sentidos, focando aspectos analógicos entre realidades (semelhanças que saltam as relaçóes lógicas, causais), entre o dentro e o fora (interior-exterior, sujeito-objecto), entre categorias, faculdades e sentidos (a sinestesia é um recurso típico do Simbolismo como o símile desenvolvido o fora da poesia homérica), que a inteligência analítica separa.

Veja-se a este respeito como na análise de Esther de Lemos à "autêntica obra-prima» ${ }^{82}$ do poema "Chorai arcadas" [Violoncelo], o prodígio de associaçôes de imagens que nele se desdobam é subtendido por uma «lógica» que entretece as imagens num todo, numa misteriosa unidade. Por outras palavras, as imagens náo se acumulam caoticamente, numa

${ }^{79}$ Apud Pereira, op. cit., p. 56.

${ }^{80} \mathrm{H}$. de Régnier, apud Pereira, op. cit., p. 80, nota 57.

${ }^{81}$ Apud Rubim, Experiência da Alucinação Camilo Pessanha e a Questão da Poesia, p. 40.

${ }^{82}$ Spaggiari, O Simbolismo na Obra de Camilo Pessanha, p. 65. 
dispersão desconexa, mas surgem encadeadas segundo relaçôes que não são lógicas, causais, de sucessão espácio-temporal, acabando, porém, por fazer sentido. Este sentido erguido nas ruínas do sentido lógico é explicado por Jean Cohen pelos conceitos de desvio e redução de desvio. Tomada literalmente, mais bem, denotativamente, este poema representa um desvio relativamente à inteligibilidade lógica (as arcadas do violoncelo que se transmutam em pontes aladas, donde adejam os arcos e sob as quais se despedaçam barcos...), uma transgressão sistemática do código linguístico (desvio para o alógico, como diz Todorov), cujo choque concita uma reacção do espírito a restabelecer a coerência do texto, reinterpretando-o de outro modo. Quer dizer que o desvio não desemboca numa agramaticidade incompreensível, pois à desestruturação que realiza sucede uma reestruturação de uma outra ordem. Esta reestruturação ou redução do desvio efectua-se passando-se da forma mentis lógico-conceptual para o campo conotativo e afectivo. $O$ que impede a desagregação do discurso, restabelecendo o fio interrompido, é afinal o deslize do plano conceptual para o plano afectivo, a intervenção do "sentimento» com a sua "lógica» própria, dizemos nós ${ }^{83}$. Esse autor efectuou um estudo estatístico sobre a frequência dos «desvios» poéticos no Classicismo, Romantismo e Simbolismo, sendo uma das suas conclusóes, que importa para a poética do Simbolismo - antidiscursivismo, antiprosaísmo, etc - a de que a impertinência semântica (por exemplo, «negros perfumes») aumenta de 3,6\% nos clássicos para 46,3\% nos simbolistas. É que, na simplificação adrede efectuada por João Gaspar Simóes, "a poesia clássica contava, a poesia moderna sugere ${ }^{84}$.

Deste ponto de vista, então, a poesia simbolista exprime a tendência de contracção do significado no significante ${ }^{85}$, o movimento para a concentração, para a condensação do significado.

${ }^{83}$ Para uma exposição crítica desta tese de Cohen vide Ricoeur, Metáfora Viva, pp. 227-230.

${ }^{84}$ João Gaspar Simões, «Estudo crítico», in Poesias, de Mário de Sá-Carneiro, Lisboa, Ática, 1991, p. 12.

${ }^{85}$ «Ser conciso (quer dizer encurtar o significante sem diminuir a densidade do significado)», Barthes, (apud Rubim, A Inscrição Espectral: Poética do Vestígio em Camilo Pessanha, p. 98). A mesma ideia em Erza Pound: "grande literatura é simplesmente linguagem carregada de significado até ao máximo grau possível», apud Cardoso Gomes, op. cit., p. 35. 
No Simbolismo, duas direcçôes interpretativas se podem traçar, consoante se privilegia um dos termos do par saussuriano, ora o significante, ora o significado ${ }^{86}$.

A segunda aponta para a dimensão metafísica do Simbolismo, a reposição do sentido do mistério, a redescoberta do sagrado, abeberando das fontes do esoterismo e do ocultismo, e também no Catolicismo (o imaginário litúrgico, nomeadamente).

Este ver o invisível no visível pode configurar um ímpeto ascencional a que se pode dar o nome de platonismo e que percute no lema do Simbolismo russo a realibus ad realiora. É uma aspiração que se pode rastrear em alguns autores simbolistas, como tem sido assinalado: apostar na poesia como substituto da religião tradicional.

Com efeito, a espiral do símbolo pressupóe, no élan de recuperar faculdades perdidas, uma psicologia das profundidades. Aquilo que Mallarmé designava por "ruisseau primitif» exprime a ânsia da linguagem poética, decantada, de aceder ao murmúrio daquilo que Jung designará por arquétipos ${ }^{87}$.

A demanda da origem, do fundo...A poesia convizinha com o mito e talvez lhe devesse ceder a primazia, como concede Mallarmé: «os livros não são talvez uma coisa tão necessária: alguns mitos seriam suficientes...». Trata-se menos da ideia da poesia como criadora de mitos (segundo uma iniciativa individual) do que seu receptáculo e seu fermento. $\mathrm{O}$ movimento de autognose deve, no aprofundamento do individual, desvelar o universal e o colectivo. O mito de Narciso, no Simbolismo, quis exceder o enclausuramento narcisista: o espelho da linguagem poética deve reflectir mais que o eu ou a consciência. Alusiva, hieroglífica, a poesia evoca o outro da linguagem.

Em contrapartida, a primeira, a que privilegia o «significante», coloca o acento na linguagem em si mesma, no texto: o celebrado

${ }^{86}$ Orientação recolhida por Fernando Guimarães em Claude Abastado, "Doctrine symboliste du langage poétique», apud Guimarães, Poética do Simbolismo em Portugal, p. 21, nota 5.

${ }^{87}$ Nesta linha se pode situar a preferência de Maeterlinck pelo símbolo a priori, que "serait plutôt inconscient, aurait lieu à l'insu du poète, souvent malgré lui» em detrimento do símbolo de "propos délibéré» (Cf. Seabra Pereira, op. cit., p. 79). Esta aspiração a deixar o mito falar converge com a perseguição do ideal de uma linguagem poética mística, arcaica, a Ursprache de Heidegger, que deixasse que o ser, sem mediação (uma ontologia directa!), se exprimisse a linguagem dos deuses que Platão no Crátilo distingue da linguagem humana abastardada. 
ideal da poesia pura $^{88}$ pode implicar, em última instância, que a poesia não encontra fundamento senão em si mesma.

A procura do «raro» vocábulo, ou a refontalização poética do termo comum, a recuperação do brilho perdido pelo uso, são duas démarches distintas da mesma injunção: a de perseguir o rasto da essência da poesia pura.

À estética da representação tradicional sucederia uma estética da figuração, em que o texto dado encontra o seu posto numa rede composta por outros textos cuja soma, irrepresentável, seria o Livro. Simplificando, o texto remete para o texto, no limite, um texto total e infinito, em vez de remeter centrifugamente, mimeticamente, para uma realidade extra-literária ${ }^{89}$.

Porém, esta prefiguração do reinado da linguagem assenta numa proposiçáo metafísica, segundo Mallarmé: «a natureza tem como finalidade desembocar num belo livro». Não se diz que a natureza deve desaparecer depois deste parto. A teleologia da natureza é inerentemente poética.

Realça-se esta linguagem "metafísica» (recorde-se outra frase famosa de Mallarmé - «Il doit y avoir quelque chose d'occulte au fond de tout, je crois décidément à quelque chose d'abscons, signifiant fermé et caché, qui habite le commun» - em que se surpreende a velha distinção metafísica entre o véu da aparência e o sentido oculto das coisas), com o objectivo de ilustrar como as teorias e as práticas simbolistas da linguagem poética não predicam (ainda) a redução da referência ao sentido (nos termos de Frege), a obliteração da função referencial (por mais indirecta, vaga ou refundida que seja) ou, por outras palavras, como a ambiguidade própria da sugestão e do símbolo não se volve numa ambiguidade total, o que autorizaria uma liberdade interpretativa ilimitada. Este caso limite será plenamente assumido, contudo, por Valéry: «Mes vers ont le

${ }^{88}$ Para o autor de L'Après-midi d'un faune, a função órfica da poesia, a missão de romper o véu do conhecido para sugerir o desconhecido, "os esplendores situados por detrás da tumba» desemboca no nada essencial de tudo. A referida demanda do fundo, do Grund, em Mallarmé, conduz ao Ab-grund. O artista é um pontífice, mas do grande Nada. Fazendo um paralelismo fácil, o obsidiante «abismo náo sondeis» de Pessanha comparte deste desespero ontológico - o abismo não tem fundo.

89 Teríamos o movimento inverso da concentração ou concisão do significado: a dispersão, a desconstrução do sentido defendidas por Paul Bourget: «Um estilo de decadência é aquele onde a unidade do livro se decompóe para dar lugar à independência da página, onde a unidade da página se decompóe para dar lugar à independência da frase e a independência da frase para dar lugar à independência da palavra». 
sens qu'on leur prête» ${ }^{90}$. Atravessaríamos assim os umbrais do reino do nihilismo hermenêutico, na expressão de Gianni Vatimo ${ }^{91}$. O poema é, para Valéry, o jogo, a dança, entre som e sentido, residindo a sua significação nesse intervalo, necessário para dois espelhos se reflectirem, dispensando qualquer «fora». Nada há por detrás do poema. Ao invés, a prosa avança como uma marcha. Trata-se de uma revolução da revolução, a conclusão lógica das premissas de uma «hipertrofia da linguagem» característica do Simbolismo, na designação, originariamente pejorativa, de Fialho de Almeida?

A esse nihilismo interpretativo chama Richard Rorty pragmatismo forte (cuja "premissa» maior recusa a verdade como correspondência com a realidade; no contexto, o referente do texto e a intenção do seu autor empírico): os seus adeptos não se dirigem nem ao autor nem aos textos para perguntar quais são as suas intençôes, mas visam «bater o texto de maneira a adaptá-lo aos seus propósitos» ${ }^{92}$. Julgamos esta posição como um anything goes interpretativo-destrutivo: não o que o texto diz, mas o que queremos que o texto diga.

Nesta linha, a do não apagamento da função referencial, nota também Fernando Guimarães que os autores simbolistas não atingiram o radicalismo de textos como as enumeraçóes caóticas de Walt Whitmann ou, posteriormente, a escrita automática dos surrealistas, que praticaram o triunfo do aleatório, postergado, sob o nome de hasard, por Mallarmé. Importa notar, contudo, que a escrita automática surrealista supóe a anterioridade do vivido (inconsciente, onírico, instintual...) que a escrita descarrega, sem, putativamente, a mediação ou o controle da inteligência. Também a literatura surrealista não rasura totalmente a função referencial (o signo é signo de...).

Aliás, a poética surrealista é servida por uma metafísica, se bem que sui generis, como se depreende do sufixo sobre-realismo. A meta do "ponto supremo» responde por esse impulso metafísico, mas que subverte a direcção ascencional da tradição que postula as distinções e oposiçóes entre corpo e alma, sentidos e espírito, alto e baixo, vida e morte, etc., as quais o Surrealismo quis abolir, tirando da sua mistura, do entrechocar das antinomias a faísca iluminadora da unidade do real ou sobrerreal.

${ }^{90}$ Guimarães, «Simbolismo: a Procura da Originalidade», in Simbolismo, Modernismo e Vanguardas, Lisboa, INCM, 2004, p. 22, nota 2.

${ }^{91}$ Cf. Gianni Vattimo, La Fin de la Modernité, Paris, 1987, p. 126.

${ }^{92}$ Cit. in Eco, op. cit., p. 34. 
Talvez seja mais prudente, perante esta oscilação entre um pendor metafísico (platonizante, no sentido mais geral de impaciência perante os limites do sensível, do visível e da irreprimível ânsia de os ultrapassar) e uma rebusca textual imanentista, mas que não progride ainda, a nosso ver (Valéry é pós-simbolista e, contrastando com os surrealistas, mantém uma devoção absoluta pela forma - «as obras belas são filhas da sua forma»), para eleger como único objecto da poesia ela mesma, falar de Simbolismos em vez de Simbolismo. Como os barrocos tinham horror ao vazio, não poucos actualmente têm horror a qualquer insinuação de essencialismo.

Visto retrospectivamente, a modernidade do Simbolismo estaria, como consequência da sua paixáo pela ruptura e pelo novo, inaugurada pelo Romantismo ${ }^{93}$, na instauração na poética do ideal de uma revolução permanente. Essa obsessão de «recriar a linguagem poética», além da propugnação, em autores como Stuart Merrill, do verso livre, não rimado, e do abalar da distinção secular entre verso e prosa (que permanecia incontestável até ao século XIX), implica a activação da crítica poética, em permanente estado de incessante pesquisa.

Se a pedra de toque da modernidade literária residiria na acentuaçáo da reflexão crítica e teórica, ou como diz Lacoue-Labarthe, na constituição da «idade crítica por excelência - quer dizer, a "idade"[...] na qual a literatura [...] se entrega à busca exclusiva da sua própria identidade» ${ }^{94}$, o Simbolismo constitui um momento marcante do devir da modernidade.

Ora, a necessidade ou a indispensabilidade dum «educado senso crítico» na produção de uma poesia viva é uma das ideiaschave do principal texto crítico do poeta, a recensão a Flores de Coral, de Alberto Osório de Castro, e que atestará, à partida, da modernidade da poética de Camilo Pessanha. Mas antes de incidir a nossa análise nesse texto reflexivo, não é despropositado

${ }^{93} \mathrm{O}$ que autorizaria a ver no Simbolismo um ramo do megaperíodo romântico. Quanto à pertinência deste ponto de vista e às reservas que se lhe podem opor, vide Seabra Pereira, O Neo-Romantismo na Poesia Portuguesa (1900-1925), Coimbra, Tese de Doutoramento, 1999, pp. 3-6, onde se refere a posição de Octavio Paz e se aproxima a "tradição do Heterogéneo», expressão cunhada por José Guilherme Merquior em O Fantasma Romântico e Outros Ensaios, Petrópolis, Vozes, 1980, p. 45, com a "tradição do novo», de Harold Rosenberg.

${ }^{4}$ Apud Rubim, Experiência da Alucinação Camilo Pessanha e a Questão da Poesia, p. 33. 
determo-nos um pouco mais na natureza da influência de Pessanha no primeiro modernismo (marco fundamental do devir da modernidade literária em Portugal).

Se essa influência foi reconhecida entusiasticamente pelos próprios modernistas, como vimos, os críticos dividem-se relativamente ao aspecto que terá suscitado a admiração. Para António Quadros, é o ideário decadente comum, a unidade entre uma vida decadente e uma obra decadente que entronizou Pessanha como mestre para a geração de Orfeu - «Tal como Nobre, tal como Pessanha, tal como Montalvor, também Fernando Pessoa e Mário de Sá-Carneiro foram manifestamente poetas decadentistas» ${ }^{95}$. Bastaria, para desfazer qualquer equívoco, reter o título sonoramente decadentista de uma das revistas saídas dessa escola, Exílio. No extremo oposto, na opinião de Franchetti, é ao nível da expressão literária, ou à "forma específica de organizaçáo do verso e do discurso lírico, isto é, a sua dicção e a sua poética» que se deve reportar a fonte da influência «e náo o rearranjo da tópica finissecular pelas obsessôes individuais» ${ }^{96}$. Contra esta última perspectiva, conjugada com os aspectos formais inovadores, não teria sido decisiva a imagem exótica e «escandalosa» do exilado opiómano que delapidava incessantemente os seus poemas em decocção mental para a recepçáo entusiástica da obra do poeta? A ampla zona de intersecção estilístico-temática entre a poesia de Pessanha e de Mário de Sá-Carneiro faz Cabral Martins inverter os epítetos e pôr Sá-Carneiro como «simbolista» e Pessanha como "modernista» ${ }^{97}$. Também Óscar Lopes estreita as relações entre Pessanha e Fernando Pessoa, como já se referiu, encontrando o ponto de articulação na temática: «Podemos concluir que a temática do nosso único simbolista verdadeiro é já, em gestação adiantada, a do nosso melhor poeta modernista» ${ }^{98}$.

${ }^{95}$ Quadros, op. cit., p. 26.

${ }^{96}$ Franchetti, op. cit., p. 63.

${ }^{97}$ Cf. Cabral Martins, «Pessanha e Sá-Carneiro: intersecçóes», in Colóquio/ Letras, no 117/118, 1990, pp. 193, 194.

${ }^{98}$ Óscar Lopes, Entre Fialho e Nemésio, p. 125. Sobre as nuances da atitude de Pessoa relativamente ao Decadentismo e Simbolismo, que oscila entre uma total desvalorização e o reconhecimento da sua influência, vide Guimarães, «A Geração do Orpheu e o Simbolismo", in Simbolismo, Modernismo e Vanguardas, Lisboa, INCM, 2004, pp. 49-58. 


\section{6 - Análise da crítica a Flores de Coral de Alberto Osório de Castro}

Camilo Pessanha começa o seu artigo por utilizar a preterição: não pretende fazer a crítica de um livro de poesia, mas vai, afinal, fazê-lo. Mais que protesto de modéstia («modesto dilettante das letras») ou justificação do carácter sumário do artigo («despretensiosa notícia», «rápida leitura»), interessa reter as razóes de fundo que aduz para duvidar da possibilidade da crítica da poesia.

«O valor estético» das obras poéticas só é cognoscível ou experienciável directamente, lendo-as, devido à essência subjectiva da Poesia ("Arte essencialmente subjectiva», "para alguns dos seus mais delicados cultores quase táo exclusivamente subjectiva como a Música»). Além do tópico simbolista da aproximaçáo da poesia à música ${ }^{99}$, que é óbvio, seríamos tentados a reconhecer nestas palavras a afirmação de Rougemont de que o Simbolismo significou a vitória ou o retorno do individualismo na arte e também, no bandear da poesia para a esfera do "subjectivo», a implícita recusa do «objectivismo» parnasianista e realista da poesia.

Mas o desenrolar do texto faz ver a precipitação desta pré-leitura, pois valoriza-se mais adiante em Alberto Osório de Castro a indiferença por "preconceitos de escola» e um «irrepreensível soneto parnasiano», intitulado "Yellow Town».

A natureza subjectiva da poesia torna improvável a sua dissecação exaustiva por uma crítica científica, pois, entre os estratos constitutivos da linguagem poética, a que Pessanha destaca, na sequência da aproximação da poesia à música, é a «euritmia», insusceptível de ser decomposta numa soma de factores, por «diferentes», «complexos» e de variável «importância». Uma complexidade de gestação subtende a «luminosidade simplicidade aparente» da Poesia. Só uma análise que desse conta desta miríade de factores é que mereceria o nome de científica ${ }^{100}$. A prudência

${ }^{99}$ Nos «delicados cultores» da poesia, Pessanha visaria provavelmente um Verlaine. Numa carta a Carlos Amaro, informa que veio a descobrir que o ritmo dos seus decassílabos era o mesmo do verso de Verlaine. "Se eu aqui tivesse a obra do grande poeta (tenho-a em Macau), havia agora de estudá-la sob esse aspecto.», Camilo Pessanha, Contos, Crónicas, Cartas escolhidas e Textos de temática chinesa, 1988, p. 93. O epíteto «delicados» sugere o carácter fino, cuidado, minudente, do labor poético, uma arte de filigrana.

${ }^{100}$ A história da literatura regista a tentativa de instituir uma "poesia científica» com o nome de "evolutiva-instrumentista», propugnada por René 
comanda a introdução de um cauteloso "ainda» - "não existe ainda feita a sua análise (e só essa mereceria o nome de crítica científica)» - na consideração dessa possibilidade.

Essa dúvida não se compagina facilmente com a asserção posterior de que «constituem as Flores de Coral a mais cabal demonstração de que não são antinómicas a poesia e a análise científica», pois Osório de Castro realizou o afã, num apêndice («curioso») à sua obra poética, de pôr diante dos olhos do leitor os «segredos» que explicam a "génese daquela», e de que Pessanha dá conta: as datas, o lugar, o momento, a impressão, leituras, predilecçóes espirituais, viagens, «as suas próprias características étnicas e remotos atavismos que influenciaram o seu trabalho mental».

Desse modo, o simbolista Osório de Castro não enjeita transmutar-se em crítico positivista da sua própria obra. Pois os factores identificados que presidiriam à génese da obra faziam parte do arsenal teórico-crítico da crítica literária de feição positivista, por exemplo, de um Hippolytte Taine. Talvez, a dúvida que Pessanha havia colocado perante a exequibilidade de uma crítica merecedora do epíteto de científica tenha visado, diagonalmente, a pretensão do Positivismo literário, entáo muito influente, de explicar cientificamente, deterministicamente, a génese da produção poética.

Em seguida, não prescinde Pessanha no seu juízo valorativo de entidades extratextuais como a biografia, «imaginação», «psicologia», «vida», ligando a boa poesia à personalidade do poeta. A pedra de toque do autêntico poeta reside na perseverança da sua vocação, no confronto com a prova do tempo e da sua lima, em contraste com os poetastros, «a legião de poetas mínimos», que se precipita em publicar os borróes dos seus incipientes jorros líricos, sob o influxo da "primeira exaltação amorosa da adolescência».

Ao que parece (hoje não poderíamos afirmá-lo), a tendência

Ghil e discípulos, nascida, portanto, do seio da corrente simbolista, que justamente intentava sistematizar as regras combinatórias desses «factores» que estruturam a "euritmia» verbal. Os seus cultores pretendiam assimilar vogais e consoantes a determinadas sonoridades musicais as quais se ajustavam, por relaçóes constantes e necessárias, a definidos sentimentos e ideias. $\mathrm{Na}$ posse dessa técnica, qualquer um poderia forjar poemas com certificado de qualidade. Este projecto, fatalmente condenado ao fracasso, vale por confirmar a profunda consciência estética dos autores que aderiram ao Simbolismo (cf. Seabra Pereira, História Critica da Literatura Portuguesa, Vol. VII, Verbo, 2004, pp. 26, 27). 
para compor versos era comum no estudante universitário de então e, também, o vezo de publicá-los em letra de imprensa ${ }^{101}$. Ora, esta precipitação, esta ingenuidade, esta gloríola, são visadas pelo sarcasmo de Pessanha, que já o havia aplicado ao livro do novel poeta António Fogaça, Versos da Mocidade (1887). Cerzir versos e rimas sob o deslumbramento do primeiro amor é tão efémero como o sentimento e a mocidade que os alimentam. $\mathrm{O}$ trabalho e o casamento rapidamente sufocam a curta musa dos verdes anos. Ao invés, no autor de Flores de Coral, «a vida real» não rasurou, antes escavou as nascentes da sua poesia.

Censurava Pessanha a António Fogaça a ausência de «um princípio, uma noção, um sentimento (...), presidindo à concepção de todas as suas obras». O livro de Osório é dispersivo ("são uma simples colecção de composiçôes autónomas»), mas o que lhe confere unidade é «o tom idêntico da emoção e a coerência do critério filosófico». Não explicita logo estes elementos unitivos, louvando a independência da "estética» do autor, que vaza a sua matéria poética numa gama diversificada de formas, métricas e estróficas, sejam tradicionais ou revolucionárias, de todas extraindo "admiráveis efeitos de plasticidade». Esse "tom idêntico de emoção» é identificado como «um véu de ténue melancolia». O adjectivo indica a contenção emotiva, muito apreciada por Pessanha que desadora os derrames sentimentais ou encarecimentos declamatórios, como havia frisado na crítica ao livro de Fogaça.

E a influência de Saturno cresce com a passagem da idade. Do miradouro dos seus quarenta anos, Osório de Castro contempla saudosamente o caminho percorrido e perscruta o seu termo, no «oceano do Aniquilamento». Se pranteasse a juventude irremissível ou ilusóes perdidas, esse pathos revelaria que estava encadeado a uma "compreensão da existência» "mesquinhamente egoísta». O que liberta o autor do egocentrismo é a vigilância irredutível dum apurado "senso crítico", o desdobramento do "esteta» no "consciencioso observador científico». Que funçóes são assacadas a estas duas faculdades?

A função do esteta é a de indagar no tema «a quantidade de beleza que poderá produzir», encontrando-lhe a forma justa; a

${ }^{101}$ Para o poeta, parece ser um dado irrefutável a conjugação entre juventude e lirismo poético: lê-se em "Introdução a um Estudo sobre a Civilização chinesa» que "naquela quadra da vida", a juventude, "até os menos curiosos das letras sentem cachoarem-lhes nas veias torrentes de inspiração poética.», Pessanha, Contos, Crónicas, Cartas escolhidas..., p. 121. 
do cientista é a da interpretação, a um nível de segundo grau, descortinando no "fenómeno», sob a «superfície» da "aparência», o "fundo", «a natureza íntima das coisas, as relaçóes e a fatalidade dos seus destinos». A este exercício analítico não escapa a parte que cabe ao sujeito: no "fenómeno de cada uma das aparências que interpreta não se esquece de discriminar a participação da sua própria alma, o espelho em que se revelam». E o que o «poder de dissociação» dessa inteligência sonda no "íntimo» das coisas? A morte, inextrincavelmente unida ao amor e à vida. A presença pervasiva, obsidiante da morte infiltra-se por todo o lado. Pessanha emprega verbos «vitalistas» para exprimir o reinado da mors imperatrix mundi: "Palpita na luz dos astros, estua na seiva das florestas virgens, ondula no colubrino estorcer-se das bailadeiras indianas, satura o olhar indagador e sério (...)». Não lembram expressôes como "poder de dissociação», "acuidade da sua visão» o verso de "Vénus $\mathrm{II}$ ", "E a vista sonda, reconstrui, compara,»? Noutros termos, o cunho reflexivo que Pessanha valoriza na poesia de Osório de Castro náo é revertível para a sua própria poesis?

A mesma contenção que torna sóbria a melancolia do poeta se estende à sua filosofia, polindo-a de todo o tique professoral ou didactismo: "uma e outra apenas impregnam as Flores de Coral, e delas se evolam como um perfume subtil». Similarmente, «didáctica» é apodo que não convém de todo à poesia de Pessanha, pois desde Esther de Lemos que se tem notado que "A Clepsidra não é um livro de ideias», acrescentando que «em toda a obra não haverá um poema que possa com probabilidades de êxito reduzir-se a prosa corrente» ${ }^{102}$. A problemática do tempo é patente e obsessiva na escrita do autor: no entanto, a palavra abstracta "tempo", não surge nunca, não se encontra um verso semelhante ao de Lamartine, "O temps, prends ton vol», ou outros afins.

Se não é uma poesia que revista de forma poética proposiçóes filosóficas, tal não invalida que possa ser considerada uma poesia filosófica, no sentido em que se debate com a interrogação filosófica por excelência sobre o sentido ou não sentido da existência humana e do mundo. A fórmula dessa interrogação em Pessanha é «sondar o abismo». A indagação filosófico-poética não se confina ao ser e à vida individual do poeta. A dor que se estorce na sua poesia não é simplesmente pessoal, "mesquinhamente egoísta», nas palavras de Pessanha neste artigo, mas uma dor cósmica, flagelando a longa

${ }^{102}$ Esther de Lemos, op. cit., p. 23. 
marcha da caravana do género humano, como se lê em «Branco e Vermelho». A indispensabilidade da dimensão filosófica na mais elevada poesia é sugerida na conferência que o autor proferiu «Sobre a Estética chinesa» quando a certo passo sustenta que «os Chineses não conseguiram levantar o seu espírito até à noção de arte pura ou arte filosófica: a sua arte é apenas decorativa ou de aplicação» ${ }^{103}$.

Temos então como sinónimos arte pura e arte filosófica, contrastadas pela arte que é apenas decorativa ou de aplicação. A arte pura ou filosófica seria a arte soberana, aquela que recusaria ser secundária, decair em mero instrumento para a consecução de um fim que lhe fosse externo.

A coexistência de um senso estético e um outro científico num poeta e sua obra dá a tónica para a equação mais lata entre arte (poesia) e ciência. "O sonho da idealidade» náo deve sentir-se acossado pelo progresso científico (na sua dupla dimensão teórica e prática ou técnica - o que a expressão tecno-ciência sintetiza), porquanto «a situação do homem»" ${ }^{104}$ (seríamos tentados a traduzir pelo velho especismo «a natureza humana») permanece imutável, alanceada pelo «incognoscível», cujo "abismo» o alargamento das descobertas científicas não cobrirá jamais.

Infere-se daqui que Pessanha não alinha nas hostes anti-ciência ${ }^{105}$, no sentido em que não denega os efeitos positivos nas condiçóes, não só morais, mas sobretudo materiais da existência humana, mas traça limites à explicação científica. Se a melhoria das "condiçôes materiais» e o alargamento do conhecimento científico náo cerceiam a possibilidade da arte, por outro lado, essa evolução não se reflectiu, para Pessanha, num progresso paralelo

103 Pessanha, Contos, Crónicas, Cartas escolhidas..., p. 118.

104 «Homem», enquanto tal. Europeu ou não, urbano ou rural, capitalista ou proletário, analfabeto ou instruído...

${ }^{105}$ Entre as muitas manifestaçóes da rejeição da ciência, ou melhor, da sua pretensão positivista de erigir-se em único conhecimento válido e definitivo, é particularmente vívida a voz da novela de Dostoiéwski, Cadernos do Subterrâneo, Lisboa, Assírio \& Alvim, 2000. O narrador da novela, neurasténico e amargo, coloca-se deliberadamente à margem do que é normal e positivo. Insurge-se contra o «edifício de cristal, inquebrantável por todo o sempre» da ciência, «ao qual não se pode mostrar a língua às escondidas nem fazer uma figa com a máo no bolso» (ibidem, p. 57), considera arrogante, «uma coisa insuportável» o dois mais dois serem quatro, não vendo porque o há-de preferir ao dois mais dois serem cinco (ibidem, p. 55). Em rigor, pode-se compreender uma proposição matemática e não aceitá-la. Desde Descartes que se pode dissociar o assentimento da razão e o da vontade. 
nas artes, pois a sua época não teria produzido obras comparáveis com as da antiguidade, «inexcedíveis», «inigualáveis» «obrasprimas». Sem dúvida, não ocorreria a Pessanha misturar esfinges com guindastes (como foi o intento de Mário de Sá-Carneiro) e provavelmente recuaria de horror se lesse os poemas futuristas de Álvaro de Campos. Este lado «conservador» da sua ideia de arte pode-se detectar na conferência que proferiu sobre a estética chinesa, nomeadamente, quando assevera que os chineses não «se elevaram jamais até ao mundo de luminosa idealidade que pelos Gregos foi encarnada na imarcescível beleza das estátuas de Vénus e Apolo» ${ }^{106}$.

Retornando ao texto crítico sobre Flores de Coral, a ciência portanto nunca explicará tudo. Porém, os limites traçados ao poder explicativo da ciência são negativos: é o sem sentido do incognoscível, que provoca angústia agnóstica, no sentido original do termo cunhado por Huxley ${ }^{107}$.

Dessa zona obscura não se pode afirmar nada, trata-se de um buraco negro para o pensamento. Aniquilamento, nada e morte. A situação espiritual do poeta é assim trágica, irresolúvel. Os acenos da beleza, as suas fulguraçôes fugidias são breve viático para quem se sabe irrefragavelmente emboscado pelo sem fundo do abismo ${ }^{108}$. Aliás, essas cintilaçôes tornam mais penosa a consciência da sua condição de exilado.

\section{7 - Decadentismo e Simbolismo na CLEPSIDRA}

Antes de abordar a problemática enunciada no título (dizer algo sobre Simbolismo em geral sem o referir à obra do autor

106 Pessanha, Contos, Crónicas, Cartas escolhidas..., p. 119.

107 O termo foi inventado por Thomas Henry Huxley para, através do prefixo de negação, exprimir o seu desacordo relativamente à certeza gnóstica de conhecer todos os mistérios.

${ }_{108}$ Poder-se-ia perguntar como se compatibilizam a existência da beleza, princípio de sentido, com um nihilismo onto-antropológico de base.

Noutro plano, o da relação entre teoria, estética e acção política, é comum em muitos intelectuais e artistas «progressistas» ou «revolucionários» a coexistência entre um pessimismo radical onto-antropológico e um engajamento político-revolucionário acentuado. Diz-se de Orwell que era pessimista e activo e, no pólo oposto, Mounier, em O Personalismo (Emmanuel Mounier, O Personalismo, Lisboa, Ed. Moraes, 1976, p. 176) cita uma personagem de Espoir, de Malraux, "Um homem simultaneamente activo e pessimista é ou será um fascista, a não ser que exista uma fidelidade atrás de si» (reportando-se aos anos trinta e no pressuposto de que o fascismo puro é revolucionário e não conservador). 
em apreço é improcedente), não será ocioso dizer qualquer coisa, em pinceladas breves, sobre a difusão do Decadentismo e Simbolismo em Portugal. Um ponto a esclarecer é a do relevo que Decadentismo e Simbolismo tiveram na produção poética nacional no último decénio do século XIX. Foi este o movimento dominante?

Gustavo Rubim defende a "condição marginal e quase deliberadamente menor com que o simbolismo emerge nas letras portuguesas» ${ }^{109}$; porém, a argumentaçáo que desenvolve para apoiar esta opiniaáo não é consistente. Coloca como premissa geral uma citação de Eduardo Lourenço que identifica, na preocupação com "o ser e o destino de Portugal», "o horizonte de aventura literária» e "a motivação mais radical e funda de quase toda a grande literatura portuguesa do século XIX»; constata em seguida o carácter degagé e cosmopolita do Simbolismo (o princípio da arte pela arte, que vira costas ao "destino português») e conclui da menoridade do Simbolismo português. Evidência dessa marginalidade é a polémica sobre a cesura, cruzada pelas revistas coimbrãs Boémia Nova e Os Insubmissos, de natureza a mais superficial e, à distância, quase bizantina. Mas no desenvolvimento deste raciocínio Rubim parece cair na crítica que faz, meia dúzia de páginas volvidas, à tendência seguidista de se ver o Simbolismo francês como modelo perante o qual o Simbolismo indígena constituiria uma versão inferior. A menoridade do Simbolismo português explica-se, afinal, pela sua submersão sob a vaga do nacionalismo literário ou por não possuir uma elaboração teórico-crítica comparável ao Simbolismo gaulês?

O relevo do Simbolismo português (que partilha o palco da literatura finissecular com o Naturalismo e o Neo-garretismo) pode ser medido e provado, a contrario, pela influência, a nível estilístico, que acabou por exercer sobre opositores como Guerra Junqueiro e Fialho de Almeida, tal como o desadorado Realismo influenciou Camilo Castelo Branco em obras como A Corja, Novelas do Minho ou A Brasileira de Prazins.

Mas a rubrica deste capítulo fala de Decadentismo e Simbolismo, cuja ordem não é, como vimos no caso francês, aleatória, pois supóe uma sequência, não só de ordem temporal, mas também de ordem valorativa. Admitida esta distinção e tensão, convém averiguar se se podem demarcar esses conceitos na cena literária portuguesa e para que lado em termos quantitativos

${ }^{109}$ Rubim, Experiência da Alucinação..., p. 51. 
e qualitativos a produção poética lusitana, filiável ora num ora noutro dos dois movimentos, pendeu.

Para Seabra Pereira, que estudou a fundo toda a produção poética decadentista e simbolista nacional, a figura da ligação entre esses dois movimentos não é a da síncrese, mas a da superação/ transmutação. Mas o pêndulo inclina-se, no saldo entre as duas correntes, decididamente para o lado do Decadentismo ${ }^{110}$.

Esse primado é, aliás, mensurável quantitativamente: o número de tópicos e de páginas que este estudioso dedica ao Decadentismo excede em muito o correspondente ao Simbolismo. Somando esses tópicos decadentistas, obtém-se a seguinte série: pessimismo fatalista, inconstância e precipitaçáo desastrosa da vida, engano e desengano, desânimo e apatia, taedium vitae, desintegração íntima e doença espiritual, angústia do tempo e inquietação metafísico-religiosa, deus absconditus e fé, deísmo, panteísmo e metempsicose, esoterismo, satanismo e morbidez, fim de raça, fim de século, nevropatia e superstição, perversão cínica e sádica, algolania e dolorismo, desvio erótico, vício e exotismo, estesia do disforme e do repugnante, do horrífico e do fúnebre, sumptuarismo e mundo de engano, nevrose do rubro/ obscuridade e sons múrmuros, o Amor: tensão irresolúvel, fatalidade, morte, formas de evasão, aniquilação do sentir, mors liberatrix, impressionismos e transfiguração, poente e Outono, avatar do poeta maldito, criação e natureza da poesia, gnose poética do eu. Em contrapartida, apenas três subdivisóes são recortadas para a explanação da temática do Simbolismo: para lá da crise decadentista, a mundividência idealista e a teoria das correspondências.

As causas para este desequilíbrio são sumariamente apontadas: «mais propício, pelos vectores da sua temática, a viçar nas limitadas condições culturais e na deprimente ou agónica conjuntura sócio-política do Portugal coetâneo; menos exigente quanto à profundidade de reflexão estética e quanto à subtileza de dons criativos; defluindo mais facilmente da reelaboração da lírica romântica ou da ambígua osmose de pretensões naturalistas com uma perspectiva esteticista da degeneraçáo»" ${ }^{11}$. O ideário decadentista prestava-se perfeitamente à consciência infeliz

${ }^{110} \mathrm{O}$ carácter secundário do Simbolismo «revela-se no próprio interior da sua gestaçáo pois é do interior do Decadentismo que irrompem - sob a forma de reacçáo superadora ou de prolongamento depurado - as coarctadas manifestações simbolistas», Seabra Pereira, Simbolismo..., p. 456.

111 Seabra Pereira, op cit., p. 456, nota 4. 
da intelectualidade portuguesa finissecular. A fundura dessa infelicidade que levantou uma onda de suicídios em proeminentes intelectuais portugueses (com um dos quais, Manuel Laranjeira, manteve correspondência epistolar) levou Miguel de Unamuno a aventar a hipótese de o povo português ser um povo de suicidas, quase um povo suicida. Essa hipótese, além da canção do Fado, pressupóe, sem prova inequívoca, que o estado anímico da inteligentsia reflecte a alma do seu povo. Aliás, mesmo nessa época, em sociedades europeias tidas como mais desenvolvidas, as taxas de suicídio eram maiores. Como acautela Fernando Catroga, não se deve efectuar uma mecânica extrapolação sociológica desse fenómeno de intelectuais. No âmbito da inteligentsia, um «dado autor podia ser pessimista quanto às expectativas pessoais e optimista acerca do futuro histórico da humanidade; e, em certos casos, o contrário também era verdadeiro» ${ }^{112}$.

Regressando ao nosso autor, «A parte do imaginário decadente na poesia de Camilo Pessanha» ${ }^{113}$ que se pode subsumir no denominador comum «O mundo como representação disfórica» é profusa nos poemas de Clepsidra ${ }^{114}$. Um esperto bispo da novela D. Quixote de Graham Greene, para não perder tempo, lia as

${ }^{112}$ Fernando Catroga, "Portugal como "corpo" e "alma” (sécs. XIX/XX)», in Revista de História das Ideias, Vol. 28, Coimbra, 2007, p. 273). Como se tivéssemos apenas duas cores para pintar a realidade, é interessante reparar no advento do Neo-Romantismo (1890-1926), rubrica que reúne três correntes antagónicas, ideológica e politicamente (vitalista, saudosista e lusitanista) sob o denominador comum da representação "eufórica» de Portugal (cf. José Carlos Seabra Pereira, «Servanda Lusitana! (Ideia e Representação de Portugal na Literatura dos Séculos XIX e XX)», in Revista de História das Ideias, Vol 28, Coimbra, 2007, pp. 536-542).

${ }_{113}$ Título da segunda parte da obra L'Imaginaire de Camilo Pessanha Résonances Fin-de-Siècle et hantises individuelle, de Christine Pâris-Montech.

114 «A obra lírica de Camilo Pessanha ilustra, com abundância e intensidade, boa parte da temática cultivada pelo Decadentismo finissecular: desengano, cepticismo, fatalismo, atitude derrotista e regressiva perante a vida, auto-incitamento à aniquilação dos vãos anseios e à apatia, apelo ao alheamento e ao sono abúlico (apologia lírica da desistência numa poesia desafecta ao protesto oratório e à postura heróica onde até as exclamações e apóstrofes são apenas processos anti-assertivos da decepcionada fenomenologia da percepção); angústia do Tempo, recobrindo a jugulada inquietação metafísica de um sujeito coacto nos limites imanentistas (com simbolização críptica em «Na cadeia dos bandidos presos!») e votado ao abandono por um Deus otiosus, abscôndito ou absurdo; estesia do fúnebre, do disforme, do repugnante (até à desfocagem do tópico ofélico numa ímpar embriaguez com o odor da putrefacção, em «Vénus»); imagística de deperecimento, ruína ou extinção, etc.»; Seabra Pereira, História Crítica da Literatura Portuguesa, p. 137. 
primeiras e as últimas páginas dos livros a que por dever de ofício lançava máo. Supóe, como a maior parte, que um livro obedece a um plano e, como o soneto renascentista, que o mais importante está no fim.

Relativamente a Clepsidra, é fundada essa suposição, desde logo pelas opinióes expendidas nas críticas aos livros de Fogaça e Alberto Osório de Castro (critica no primeiro a ausência de um plano e louva no segundo a coerência resultante do tom idêntico da emoção e critério filosófico), e, sobretudo, pelo relevo prologal e poslogal do primeiro e último poema. Além disso, deve ser notado que a palavra que ocupa o título, Clepsidra, ocorre, e apenas, no poema "Final», fechando aparentemente o círculo. A leitura dos dois poemas náo deixa dúvidas sobre o «estado de alma» disfórico, derrotista que embebe a obra. Tudo é subtil em Pessanha, menos o desespero, mas um desespero que se quer «sem ruído» ${ }^{115}$.

$\mathrm{O}$ que faz ascender então a poesia de Pessanha a um patamar simbolista? Antes de considerar a argumentação do autor José Carlos Seabra Pereira, a primeira evidência de Simbolismo está no próprio título, Clepsidra. Se, como é provável, o poeta retirou a palavra do célebre verso de Baudelaire, «Le gouffre a toujours soif; la clepsydre se vide», a decisão sugere a inscrição da sua poesia no movimento simbolista, no sentido em que Baudelaire foi, pelos simbolistas, unanimemente reconhecido como o grande precursor $\mathrm{O}$ verso de Baudelaire pode ser tomado como foco iluminador do fundo simbólico e metafísico da obra: o que goteja na clepsidra não é só o tempo cósmico, mas o tempo e a finitude de cada vida humana; o que exaure o fio de água da clepsidra é o gouffre, o abismo, a morte. Esta ligação do tempo à morte e à caducidade da existência humana é demonstrada se isolarmos o som «idra» que lembra a hidra mitológica. Em «Esvelta surge!», "A hidra torpe!» é metáfora de Morte que o poeta, excepcionalmente enérgico e intrépido, anseia esmagar. Portanto, será legítimo como que incluir a morte no vocábulo clepsidra.

Analisemos os pontos que, segundo o autor, empurram a poesia de Pessanha para uma ordem de literatura simbolista. Começaremos pelos menos importantes:

-o despojamento de marcas decadentistas «como a perversão cínica, sádica e satânica» ${ }^{116}$. Este movimento de depuração talvez

115 «Inscrição».

116 Pereira, "Camilo Pessanha e a Transmutação Simbolista», in História 
possa ser surpreendido no cotejo de duas versóes ${ }^{117}$ de «Convento de Celas»:

\author{
Versão antiga: As noviças do baile proibido \\ E o prazer agora de soletrar \\ A inscrição de teu nome delido
}

\title{
Versão definitiva: Sobre a inscrição do teu nome delido! \\ -Que os meus olhos mal podem soletrar, \\ Cansados... E o aroma fenecido
}

$\mathrm{Na}$ versão definitiva foi suprimido o motivo decadentista da freira pecaminosa ou histérica em favor da criação de uma atmosfera de saudade e melancolia a evolar-se como um aroma. De facto, essa parte temática do Decadentismo, que se pode colocar sob a égide de Sade, não é patente em Clepsidra. Note-se também a alteração do estilo em que a linearidade, a cadência prosaica da versão antiga evoluem para o ritmo quebrado, suspenso, da versão definitiva ${ }^{118}$.

- o afrontamento da crise decadentista «com a inapagada juvenilidade de espírito ("Numa despedida») e com a aceitaçáo serena e vertical de tudo o que a existência pode oferecer ( Vida»)» ${ }^{119}$. Este ponto afigura-se-nos duvidoso pois o despontar de energia volitiva deflagra um fogacho que breve se apaga e a aceitação da vida tal como ela é, em «Vida», vista como eterna alternância entre a água criadora e o fogo destruidor não apresenta um cunho jovial, de aceitaçáo jubilosa das coisas como são e não como deveriam ser; é mais o encolher de ombros, o deixar andar

Critica da Literatura Portuguesa, Vol. VII, p. 138.

${ }^{117}$ A versão destas «versōes» é referida por Cardoso Gomes, op.cit., p. 53.

${ }^{118} \mathrm{O}$ estudo genético da poesia de Pessanha escapa ao âmbito do presente trabalho. Refiram-se apenas as conclusóes de Spaggiari do seu estudo das variantes genéticas e evolutivas da poesia do autor, que vêm convalidar a tese do Simbolismo da poesia de Pessanha: as sucessivas variantes desenham a curva da aproximação ao símbolo, partindo da paráfrase da realidade (a primeira versão é normalmente mais próxima da prosa do que da poesia), passando pela similitude e pela metáfora até chegar ao símbolo propriamente dito. No processo, o pretexto autobiográfico bem como a realidade imediata do poema ficam relegados para segundo plano, refinando-se a técnica alusiva e a cifra simbólica (cf. Spaggiari, «Introdução», in Camilo Pessanha, Clepsidra e outros poemas, Edição crítica organizada por Barbara Spaggiari, Lello Editores, pp. $25,26)$.

${ }^{119}$ Pereira, op. cit., p. 138. 
que precede o abatimento («-E se arde tudo? - Isso que tem!/ Deitam-lhe fogo, é para arder...»), até a sugestão da inutilidade do esforço. Neste último poema, descortinamos a valência das "arquês» dos filósofos jónios e a sugestão do eterno retorno de criação/ destruição, vida, morte, dotando o poema de fundo simbolismo.

- «a consumação pontual de valores semântico-pragmáticos ou técnico compositivos de índole simbolista, superadores do Decadentismo, como a indefinição apelativa do objecto de amor em «Interrogação" ou em «À flor da vaga, o seu cabelo verde» ${ }^{120}$ e a plurificação simbolista inerente ao interseccionismo percepcional (em «Violoncelo» ou «Passou o Outono já, já torna o frio»). Estas notas inserem-se perfeitamente na estética da sugestão indecisa, do vago e do símbolo polivalente, bem como do princípio associacionista que sobrepõe e mistura o anímico e o inanimado, pedaços da realidade e texturas afectivas.

- mas é «na recepção global de Clepsidra», na consideração do seu todo, que brota uma "sugestão de infinito», que se impóe "uma vitória ética da poesis sobre a voragem niilista simbolizada no êxtase floral sobre o pântano de «Fonógrafo» e na "serena imagem», vestida do branco refontalizante, no Leitmotiv do soneto "Desce em folhedos tenros a colina»"

Sobre o «infinito», em Pessanha não se descortina aquilo que se poderia designar por «infinito positivo» na acepção que $S$. Anselmo e Descartes lhe deram de Predicado irrefutável de Deus. Se não está a noção, pode, contudo, desprender-se a sensação de infinito, no sentido, julgo, da afirmação paradoxal de Maurice Blanchot - "é enquanto infinitos que nos sentimos limitados», - quer dizer, acima ou abaixo de nós puxa-nos o "abismo", que nos ultrapassa, que é por isso tendencialmente in-finito, sobressalta-nos a inquietude a que é inerente a colocação do enigma da existência: "Miragens do nada/ Dizei-me quem sou».

Em «Branco e Vermelho», nesta linha de rastrear vestígios de uma ânsia de infinito, lemos a expressão de uma experiência visionária, de acentos místicos, extática: «deslumbramento... todo o meu ser suspenso...pairo na luz, suspenso... no êxtase da luz».

${ }^{120}$ Ibidem, p. 138.

${ }^{121}$ Ibidem, p. 138. 
É uma experiência de plenitude, a ultrapassagem de um limite («Não sinto já, não penso»), em que a brancura da luz, ascética porque eleva, abre para o "vermelho em flor», talvez símbolo da pletora da vida.

É verdade que a metáfora do sonho do poeta («extática corola») que flutua ante "o Seu corpo» (de que desconhecemos quaisquer outras características, embora a descodificação mais óbvia será a do corpo flutuante de uma "Ofélia») sobre um paul pode significar a aspiraçáo a deixar para trás a lama, o pântano, ou, se admitirmos esta última acepção, o poder transfigurador de acrisolar o corpo morto e em desagregação da amada, por um toque de fada, num sonho de beleza; e que a imaterial, imaculada "alma de silfo" exprima o desejo de captar e unir a essência dos verdes campos e da amada, mais etérea que Beatriz, numa elevação que lembra o ir mais além ou mais fundo, no sentido do mais verdadeiro ou mais puro que se atribui ao platonismo. Imagens, belas imagens, da ânsia do ideal, de um desejo de plenitude, do querer «Perseguir doidamente os meus ideais,/ E ter fé e sonhar - encher a alma. («Caminho III»).

Sem embargo, "a voragem nihilista» não cessa de exercer o seu poder de atracção. A alma náo se arrebata em êxtase ou é alçada pelo sonho, para se fixar aí, mas lânguida e inerme deseja escapar-se para debaixo da terra como um verme, parece invejar os abortos resignados e ateus que vagamente, isto é, distanciada, indiferentemente, escutam o escorrer do tempo na clepsidra. Náo se pode falar de uma vitória, portanto, apenas de momentos inefáveis que não se consolidam em esperança ou certeza.

- é simbolista enquanto "poesia nova de reflexão sobre o conhecimento e de captação de realidades arquetípicas» ${ }^{122}$. A dimensão gnoseológica está latente ou implícita na poesia de Pessanha ${ }^{123}$, que evita, não obstante, como se viu, a forma expositiva de teses. Contudo, se quiséssemos traduzir para linguagem filosófica a intuiçãao esparsa por vários poemas, sobretudo em "Imagens que passais pela retina», púnhamos que para o poeta o

${ }^{122}$ Ibidem, p. 138.

123 Aspecto notado por Tereza Coelho Lopes: «trata-se de uma poesia fortemente intelectual que, podendo ser considerada lírica - porque centrada no eu -, se debruça quase exclusivamente sobre a problemática do conhecimento», "Apresentação crítica», in Clepsidra de Camilo Pessanha, 2a ed., Lisboa, Ed. Comunicação, 1983, p. 39. A afirmação é exagerada, no sentido em pressupóe a identificação de conhecimento com conhecimento intelectual tout court. 
conhecimento conhece imagens, fenómenos, mas inconsistentes, «miragens» evanescentes e desconexas, pois redemoinham em movimento constante. Não só as imagens visuais, mas os dados dos sentidos em geral. «Imagens» têm como exacto sinónimo, miragens ${ }^{124}$.

Quanto à presença dos «arquétipos», estes não parecem ser lançados deliberadamente (não são tratados directamente as figuras de Narciso ou de Salomé, por exemplo, muito em voga na literatura fin-de-siècle), o que talvez desse uma nota de artificiosidade à poesia de Pessanha, mas sugeridos malgré lui, o que está de acordo com as posiçóes teóricas da psicologia das profundidades, que coloca o comando desses arquétipos na zona do involuntário, do inconsciente e com o símbolo "simbolista», dado a priori, como defendia Maeterlink. Esta via interpretativa foi explorada congruentemente por autores já referidos.

- um dos pilares do Simbolismo, a doutrina das analogias entre os seres que pelo menos comungam a condição degredada da separação do Uno primordial, observa Seabra Pereira, não está presente para intérpretes como Esther de Lemos e Óscar Lopes $^{125}$, acrescentando, contudo, que "é ao constituir-se como magnífica epoché lírica dessa condição, em ordem à libertação da consciência pura, que a poesia de Pessanha realiza uma modalidade paradigmática do Simbolismo». Por epoché lírica, poder-se-á, à primeira vista, entender a recusa do confessionalismo, da ênfase oratória, da maneira de poetar a que Pessoa se referia quando, na carta que escreveu a Pessanha, via na poesia deste a ilustração da «verdade de que para ser poeta não é mister trazer o coração nas mãos, senão que

${ }^{124}$ Cf. "O Olhar de Camilo Pessanha: Imagens, Miragens», de Arnaldo Saraiva, título aludido por Rubim em "A alucinação obsidiante», in Colóquiol Letras, no 129,130 , p. 114 , nota 13.

${ }^{125}$ A referência à teoria analógica não está de todo ausente nestes autores, pois, na análise que Lopes realiza ao soneto "Singra o navio», menciona a "correspondência baudelairiana de imagens" (Lopes, "Pessanha: o quebrar dos espelhos», p. 205) que se cumpria na identificação entre a transparência das águas e o tempo e a memória. Também Esther de Lemos menciona a teoria das correspondências («Por aqui se vê como a ambiguidade de estilo (...) pode servir a teoria simbolista das correspondências.», Lemos, op. cit., p. 112). Não é, porém, de todo considerada a dimensão ou a base metafísicas dessa teoria (a de que a intermotivação dos seres poderá ter um significado sacral, órfico...) e a ideia da queda de uma plenitude originária. 
basta trazer nelas a sombra dele.» ${ }^{126}$. Mas a expressão tem um complemento nominal, epoché lírica dessa condição de exílio de modo a constituir uma "consciência pura». Significa a frase o colocar entre parênteses a atitude natural de exprimir directamente a dor derivada do carácter cindido dos seres para melhor o apreender, tornando oblíqua a angústia?

Como exemplos desta afirmação, aduz, para o «degredo ôntico», os poemas «Se andava no jardim» e «Na cadeia os bandidos presos!», «numa leitura simbolista» e, para a «reintegração escatológica» e a «mediação analógica», o díptico «San Gabriel» e os rondéis "Ao longe os barcos de flores» e "Viola chinesa».

Com efeito, a unidade que a consumaçáo do desejo promete não se cumpre, pois o anelo de unidade, de identificação visa o todo - «O que eu quis abraçar»: "A hora do jardim.../ O aroma de jasmim.../ A onda do luar...». A realização do desejo, pois, não solda o ser cindido, o mundo quebrado.

Um mundo como um cárcere, uma cadeia, onde a única serenidade possível resulta da resignação imposta pelo medo, é uma incisiva imagem desse degredo ôntico.

Já a reintegração escatológica, em «San Gabriel», é da ordem do sonho, esfumada de irrealidade: "Vem-nos levar à conquista final/ Da luz, do Bem, doce clarão irreal». O termo da viagem, reacendrada a vontade, reside numa bruma, numa "nebulosa», num «vapor» «onde, quietas,/ Fulgem as velhas almas namoradas.../ Almas tristes, severas, resignadas,/ De guerreiros, de santos, de poetas.» Esta trindade dos nossos ínclitos avoengos fulge como um fogo-fátuo e a tripla adjectivação desvitaliza-os, tornando-os fantasmas inabordáveis.

A mediação analógica ${ }^{127}$ pode-se tenuemente reconhecer

${ }^{126}$ Fernando Pessoa, Escritos Íntimos, Cartas e Páginas Autobiográficas, Obras em Prosa de Fernando Pessoa, Introdução, Organização e Notas de António Quadros, Lisboa, Publicaçóes Europa América, 1986, pp. 119-121.

127 Recordemos que Baudelaire enunciara em terminologia teológica a doutrina da analogia, mas dessubstancializando a criação - «Baudelaire não escreve: Deus criou o mundo, mas antes que o proferiu, o disse. $\mathrm{O}$ mundo não é um conjunto de coisas, mas de signos: o que chamamos coisas são palavras. Uma montanha é uma palavra, um rio é outra, uma paisagem é uma frase. [...] O texto que o mundo é não é um texto único: cada página é a tradução e a metamorfose de outra e assim sucessivamente. O mundo é a metáfora de uma metáfora. $\mathrm{O}$ mundo perde a sua realidade e converte-se numa figura da linguagem.» (Octavio Paz, Los hijos del limo, p. 108, apud Rubim, Inscrição Espectral..., p. 48). Mas a afirmação de Baudelaire pode ter uma leitura menos irrealizante, se a situarmos à luz da frase inaugural do Evangelho de S. João: 
na "cicatriz melindrosa» que vibra dolorosamente no coração do poeta por efeito da viola morosa e modorrenta. Em vez da desatenção ou de um efeito hipnótico, o som arrastado, repetitivo, acaba por ferir a atenção do sujeito, insuflando dor e perturbação, mas indefinidas. $\mathrm{O}$ que será que medeia a música sonolenta da viola morosa, a dor pessoal com a dor cósmica?

Em «Ao longe os barcos de flores», um som de flauta chora, separada, exilada da orquestra que anima a orgia. A noite é sua aliada pois o seu manto abafa a barafunda da orquestra, volvendo-se em "escuridáo tranquila» por onde o seu trilar se percute (que a orgia ocorre nos barcos de flores enunciados apenas no título, subentende-se pela repetiçáo no $5^{\circ}$ verso do sintagma "ao longe» que inicia o título). Mas que «mensagem» analógica comunica essa flauta, «só», «incessante», «viúva», "grácil», «flébil»? Porque a envolve "a escuridão tranquila», cobrindo de negro a sua viuvez? E porque é que a noite a privilegia, abafando "os festóes de som» dimanados da orgia? O seu trilar é um choro, deplorando «a dor». A dor de ser só, a de se excluir ou ser excluída da orquestra (que poderá simbolizar a multidáo, o gregarismo, le divertissement alienante, e assim na viuvez da flauta o poeta se rever na sua incurável solidão)? Porém, essa dor é declarada «sem razão», sem causa definida, sem porquê (seria abusivo ver aqui - «sem razáo» a exclusão da razão do racionalismo, incapaz de decifrar o mistério do som da flauta). "Quem há-de remi-la?», se a dor que derrama não é identificável e é aparentemente incomunicável?

É um poema sem respostas, mas é misterioso que esse verbo «remir» tenha aflorado, em forma interrogativa, suspensa, donde se pode retirar que, embora remotamente, a possibilidade de uma «redenção» tenha sido intuída. Por outro lado, se os «festóes de som» escondem a misteriosa "hora», não será a flauta o canal que a desvela? Que importa, por isso, a orquestra, os beijos ( $« \mathrm{E}$ a orquestra? E os beijos?»), deixados para trás pela noite "cauta», sábia? Assumiria assim o som da flauta um valor noético, de

"No princípio era o verbo». O proferir divino é criador do ser das criaturas. As coisas, a natureza são uma teofania do Verbo divino que é simultaneamente logos (Razão) e verbo; logo o ser das coisas é análogo pela sua origem divina e analogamente dizíveis devido ao Verbo-Uno que ao dizê-las as levou à existência. $\mathrm{O}$ verbo poético participa da fecundidade criadora e da densidade ontológica do Verbo divino. As coisas são dizíveis porque foram originariamente proferidas e criadas. Escusado será reafirmar que esta coloração teológica e metafísica da teoria das correspondências não encontra eco nas correspondências que muita da poesia de Pessanha desvenda ou sugere. 
conhecimento transracional da cisão dos seres a qual, reconhecida, possibilitaria a sua ultrapassagem - "Quem há-de remi-la?». Não se ultrapassa ou vence o que se não conhece...

A música que se desprende ora da orquestra, ora da flauta, assume, deste modo, um significado mais mallermeano que verlaineano, quer dizer, mais simbolista que decadentista, pois, mais que expressão de acordes íntimos, modulaçóes de humores pessoais, possuiria um valor ontológico ("Tudo a noite, fora...", note-se o pendor metafísico dos termos sublinhados): a orquestra da orgia exprimiria o véu ilusório da aparência, o solitário trilar da flauta o canto secreto da realidade ${ }^{128}$.

Pensamos assim que as razóes gizadas por este autor, no enquadramento sumário que uma História Crítica da Literatura concede, são suficientemente substanciais e congruentes para a afirmação conclusiva do Simbolismo da poesia de Pessanha, sem embargo de, como o autor reconhece, os temas e motivos decadentistas serem mais evidentes «a olho nu».

${ }^{128}$ Cf. José Carlos Seabra Pereira, "Ao Longe Os Barcos De Flores», in Século de Ouro Antologia Crítica da Poesia Portuguesa do Século XX, Organização de Osvaldo Manuel Silvestre e Pedro Serra, Coimbra, 2003, p. 270. Mais que a musicalidade verlaineana, neste rondel se veicula a ideia «da música mallarmeana na dupla mas indissociável vertente de estrutura musical do texto como unidade orgânica - aqui com o rondel a reger a sua circularidade pelo leitmotiv e, em particular, pela recorrência isócrona do verso "Só, incessante, um som de flauta chora» nas posiçóes determinantes de abertura, charneira e fecho da unidade poemática $\left(1^{\circ}, 7^{\circ}, 13^{\circ}\right.$ versos $)$ - e de harmonia arquetípica do real (Cosmos e equação do eu e do Todo).». 
(Página deixada propositadamente em branco) 
Parte II

Subjectividade, Sentimento e Conhecimento na poesia de Camilo Pessanha 
(Página deixada propositadamente em branco) 


\section{1 - As FIGURAS DA INSTÂNCIA LÍRICA}

Na apreciação a Flores de Coral, Pessanha observava que a maior parte das suas composiçóes eram, quanto à temática,

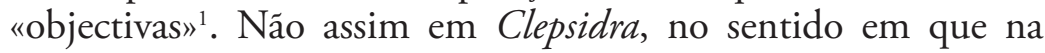
maior parte dos poemas se podem reconhecer marcas explícitas do discurso de primeira pessoa, sobretudo singular. Sob o aspecto "quantitativo», afinal, o que confere unidade à obra é a presença de um «eu», um «eu», embora, oblíquo, em risco e em desejo de naufrágio. É possível rastrear assim os termos tradicionais do discurso lírico: «eu», «alma», "coração», «olhos», etc.

Como já foi referido, a escolha do título, a sua única repetição no poema final, a existência de um poema de abertura com o elucidativo título de «Inscrição» e de um poema «Final» constituem sinais, ou pelo menos vestígios, de um plano, do esboço de uma estrutura que remetem para o domínio de uma intenção autoral.

Sobre este ponto, discordando de Franchetti, que vê na carta de agradecimento a Ana de Castro Osório de 1921 um texto meramente protocolar, ou, mais bem, «a forma mais delicada e polida de, comentando apenas generalidades, ocultar que a edição não o agradara ${ }^{2}$, Barbara Spaggiari considera-a um autêntico imprimatur de Pessanha, tanto que nos anos que lhe restaram de vida não há notícia de que tenha manifestado reservas quanto à edição de 1920. Acresce, na opinião da crítica italiana, que na primeira edição de Clepsidra se podem detectar princípios estruturais evidentes, como a divisáo simétrica dos seus trinta poemas em quinze sonetos e treze poemas a que há que somar os dois que abrem e fecham o livro e a própria distinçáo, de procedência parnasiana, entre «sonetos» e «não-sonetos», central para a execução de um "plano de produção", como ressalta de uma leitura atenta da crítica a António Fogaça, de 1888. Disto se tira que «a Clepsidra de 1920 tem, portanto, fortes probabilidades de corresponder substancialmente à vontade de Pessanha» ${ }^{3}$. Autores há que afirmam mais energicamente ainda a unidade profunda, redonda do livro publicado em 1920. António Falcão Rodrigues de Oliveira ${ }^{4}$ : «o conjunto constitui um todo, porque a obra de Pessanha tem realmente uma profunda unidade, embora

${ }^{1}$ Pessanha, Contos, Crónicas, Cartas escolhidas ..., p. 58.

2 Paulo Franchetti, «Introdução», in Clepsidra, de Camilo Pessanha, Edição Crítica de Paulo Franchetti, Lisboa, Relógio D’Água, 1995, p. 46.

3 Spaggiari, «Introdução»..., p. 16.

${ }^{4}$ In O Simbolismo de Camilo Pessanha, Lisboa, Ática, 1979, p. 98. 
esteja arrumada em duas partes»; e João de Castro Osório, em "Introdução Crítico-Bibliográfica»" "Poema uno, com início e final de intensa e profunda explicação psicológica». Não uma série de poemas, mas um Poema, de unidade fluida e móvel como o fio de água da Clepsidra, mas com balizas bem vincadas ${ }^{6}$.

Não esquecer, nesta linha argumentativa, que Pessanha alimentou a ideia de elaborar um livro, a que quis dar uma aura sacral, e que censurava asperamente no livro de Fogaça a ausência de um plano, louvando a unidade de tom e de critério filosófico no livro de Osório de Castro. É legítimo assim ver na «Inscrição» o programa, a enunciação do grande "tema» cujas variaçôes se seguirão, e que conclui, num retorno circular, no poema «Final» ${ }^{7}$. No próprio termo "Inscrição» está contida a ideia de fim. Pois que são os epitáfios, alguns deles, senão as ultima verba, a tentativa do resumo de uma vida esculpida em pedra ${ }^{8}$ ?

$\mathrm{O}$ outro poema em que este termo ocorre é «No Claustro de Celas», precisado pelo adjectivo: «inscrição tumular». O que resta "do idílio acabado» é a inscrição do nome «delido» da amada, que "a quietação do olvido" enobreceu e de que se desprende um "aroma fenecido». O tempo aqui «enobrece», em vez de destruir; preserva, esculpindo, como que limpando os acidentes para fazer sobressair a essência, como se diz das ruínas dos templos ou das estátuas gregas, tornados mais graves e solenes, polidos pelos séculos do seu policromatismo inicial, talvez porque antigo e nobre convizinhem. Podem-se aproximar os dois poemas, que partilham, além deste termo comum, a atracção pela morte, pelo seu repouso e esquecimento. O deslizar

${ }^{5}$ In Clepsidra e outros poemas, Lisboa, Ática, 1969, p. 119.

${ }^{6}$ Poder-se-á ver no desejo do Livro, com os acentos religiosos que destacámos, a metamorfose simbolista do anseio romântico de realizar a Gesamtkunstwerk, a obra total, ilimitada, de alcance escatológico e profético? (cf. o conceito de Gesamtkunstwerk in Georges Gusdorf, (L'Homme Romantique, Paris, Éditions Payot, 1984, pp. 73, 74).

7 No autógrafo do poema "Final», na posse de Carlos Amaro, lê-se uma anotação à margem, do próprio punho de Pessanha: «Última página de um livro em tempos delineado» (apud Spaggiari, «Introdução»..., p. 12).

${ }^{8}$ Maria Helena Nery Garcez, no artigo "A inscrição e a Clepsidra (Uma leitura da poesia de Camilo Pessanha)", in Letras e Letras, Ano IV, 53, 1991, p. 9, cita o livro de Job: «Oh! Se minhas palavras pudessem ser escritas, consignadas num livro, gravadas por estilete de ferro em chumbo, esculpidas para sempre numa rocha", como eloquente ilustração da "tradição milenar» da aspiração a esse sucedâneo de imortalidade que consiste em deixar-se um despojo durável de modo a permanecer na memória das gerações posteriores. 
sem ruído para o seio da terra do poema inicial não pretende senão a "quietação do olvido».

Os dois primeiros versos de «Inscrição» desenham um desdobramento, Eu/ alma. Pode-se concluir então pela distinção entre um eu superficial e um eu profundo, sendo esta zona recôndita a alma? Na tradição platónica-augustiniana, não é nunca na superfície que se vê a luz, mas no mais íntimo do íntimo. $\mathrm{O}$ acesso ao mais «alto» é facultado pelo desbravamento do mais íntimo. Mas na "alma», na "minha alma» mora a inacção, não se vislumbra qualquer via de retorno ou ascensão. Não é, deste modo, adversativa, mas copulativa, a ligação entre os dois versos: «Eu vi [pretérito perfeito] a luz em um país perdido», $\underline{\text { e, não mas, }}$ «a minha alma é [presente] lânguida e inerme», capaz unicamente de reminiscência da «luz», de entrevê-la, sem a atingir, pois os adjectivos que prostram a alma prolongam a linha disfórica de "perdido». Se Pessanha tivesse posto em maiúscula «luz» e «país», como Ângelo de Lima e Mário de Sá -Carneiro faziam proliferar os termos maiusculados, a leitura substantiva e ontológica destes versos seria muito mais confortável. Mais convidativa também a procura de tentativas de re-ligação a essa «luz», vista ou no tempo, ou antes ou fora do tempo, na poesia do autor.

Assim, toda a veemência ontológica que se queira descortinar em «Eu vi a luz» se contrai no complemento adjacente: «em um país perdido». A indefinição conferida pelo artigo impede a sua precisa localização geográfica. A perdição pode por conseguinte ligar-se à condição de exílio própria da existência humana e a luz, assaz hipoteticamente, como se tem visto, a uma pátria primigénia, indivisa, ao que Pessoa chamava o cais absoluto, anterior à queda, à cisão universal dos seres. Também não é deslocado ver no país perdido a pátria longínqua do exilado macaense, pungido pela saudade, ou a infância, ou os esplendores desvanecidos do antigo império. Eis aqui uma amostra da enaltecida reverberação vaga do Simbolismo, quer dizer, da múltipla irradiaçáo significativa da poesia simbolista, da largura das zonas de indeterminação semântica que incitam à liberdade interpretativa do leitor. É evidente que estas conjecturas caem por terra se por «eu vi a luz» se entende a mera indicação do acto biológico de nascer. Mas Camilo Pessanha não está vivo para ser interrogado sobre o significado deste enunciado?.

${ }^{9}$ Situação já observada por Sócrates no Fedro, na sua crítica contundente à escrita: os textos escritos lembram as pinturas, permanecendo mudos a quem 
Se os dois primeiros versos são de ordem constatativa e afirmativa, os dois últimos transmitem a força ilocutória do desejo, patente na interjeição, na exclamativa e nas reticências.

$\mathrm{O}$ desejo não se fixa num eventual regresso à luz, antes na ausência da luz, no "deslizar» e "sumir-se» para as entranhas da terra. É o que convém a uma «alma lânguida e inerme», o repouso no não-ser.

Comparem-se os versos da "Inscrição» com os de Maeterlinck: "Ayez pitié de mon absence/ Au seuil de mes intentions:/ Mon âme est pâle d' impuissances/ Et de blanches inactions» ${ }^{10}$. Ou com os de Mallarmé - «La chair est triste, hélas! et j’ai lu tous les livres./ Fuir!-là bas fuir!» ${ }^{11}$. A queda, a fuga para baixo, o retorno à escuridão subterrânea ... Já Teógnis sentenciava amargamente: «O melhor de tudo para o homem é não ter nascido, não ver os raios dardejantes do sol; mas, uma vez nascido, o melhor é transpor o mais rapidamente possível as moradas do Hades e jazer debaixo de uma grande camada de terra». É irresistível aproximar este pensamento de Teógnis do poema: "Porque o melhor, enfim»: o poema também quer ser um balanço final (a subordinada que inicia o poema náo tem subordinante...), sendo parcialmente sobreponíveis as primeiras oraçóes da frase do poeta grego e os dois primeiros versos do poema do português - «o melhor de tudo para o homem é não ter nascido, não ver...»/ «Porque o melhor, enfim,/ É não ouvir nem ver...». Contudo, enquanto o grego coloca uma grande camada de terra entre o inumado e a superfície, marcando assim um corte total com a vida, para o lusitano, a infiltração para debaixo da terra significa, nesse poema, mais uma subtracção à dor e quase uma vindicação por se ter safado da comédia dolorosa da vida. Anichado, envolvido por uma concha intransponível, ri porque se tornou doravante invulnerável - «E eu sob a terra firme,/ Compacta, recalcada,/ Muito quietinho. A rir-me/ de não me doer nada» ${ }^{12}$.

os interroga e, se surge alguma disputa sobre o seu significado ou se forem desdenhados, precisam do auxílio do pai (do autor), náo se salvando por si sós.

${ }^{10}$ Cit. in Seabra Pereira, Decadentismo e Simbolismo na Poesia Portuguesa, 1975 , p. 27.

${ }^{11}$ Cit. in Christine Pâris-Montech, op. cit., p. 174.

${ }^{12}$ Evidentemente, o exercício de leitura comparada, o acto de comparar versos, temáticas, não pressupóe como condição necessária que um escritor conheça as obras de outro, tanto como um Kant náo conhecia as obras de Laplace para construir a mesma teoria/ hipótese cosmológica da origem do sistema solar. A similitude de temas e formas pode promanar de uma situação 
A comparação «como um verme» antecipa já, por outro lado, a auto-deprecação a que o sujeito lírico se auto-sujeita em muitos dos poemas ulteriores ${ }^{13}$. «Oh! Quem pudesse deslizar sem ruído!»: a lírica de Pessanha é, em parte, o desenvolvimento desta exclamação $^{14}$.

Colocando o seu trabalho interpretativo sob a égide de Jung e Bachelard, Cardoso Gomes liga o pretérito-perfeito de vi com o particípio perdido, conotando a luz e país com a pátria primordial, plena, una, com a felicidade imemorial. $\mathrm{O}$ acto de ter visto exprime o ímpeto construtivo e progressivo da libido, a ascensão para a forma, enquanto a intenção de se adentrar no seio da terra manifesta a direcção inversa, a inclinação regressiva da libido, a descida ao informe, a desagregaçáo num estado larvar. Esta quadra configura uma espécie de catábase, sendo as figuras dessa descida dispostas numa hierarquia que procede do mais consciente para o mais inconsciente, do aéreo para o subterrâneo: «eu», «alma», «se», «verme». Com efeito, a ideia de "queda”, surgida aqui, perpassa a obra do poeta. Como nota Stephen Reckert, "A impressáo subjectiva do leitor é que o vocabulário de Pessanha se caracteriza por palavras referentes a descidas e quedas. (...) vêm à memória versos como "Desce por fim sobre o meu coração", "O meu coração desce», "Desce em folhedos tenros a collina», "E sobre nós cahe nupcial a neve», "desmaiar sobre o poente», ou "A cada golpe caem, / Erguem-se logo. Caem, / [...]/ Até que enfim desmaiem»" ${ }^{15}$. Esta verificação deve ser lida em conjunto com outra, náo menos iluminadora, de Esther de Lemos que,

espiritual comum (os estudos de literatura comparada têm tido como escopo apresentar "provas da íntima unidade das literaturas, especialmente das do Ocidente europeu", cf. R. Wellek e A. Warren, Teoria da literatura, 2a ed., Lisboa, Publicaçóes Europa-América, 1962, p. 60, evidenciando o intercâmbio de influências entre as literaturas das diversas naçóes) ou, como Bachelard e Gilbert Durand defendem, de regimes imaginários, de províncias do espírito semelhantes, para não falar do mapeamento psíquico delineado pela psicanálise freudiana e suas derivas.

${ }^{13}$ Conhecendo certamente o albatroz baudelairiano, o sujeito, em «Quando voltei encontrei os meus passos», compara-se a ave de capoeira: "como as aves num aviário,/ Até que a asita fofa lhes faleça...». Esta imagem de fragilidade, de apoucamento, aflora também em "Viola Chinesa», em que o coração melindrado agita, distende «as asitas».

${ }^{14}$ "Le lyrisme est le développement d' une exclamation.», Paul Valéry, cit. em epígrafe por Jean-Michel Maulpoix, "Exclamation et Développement», in Littérature, no 72, 1988.

15 Stephen Reckert, "A fono-estilística de Camilo Pessanha», in Colóquiol Letras, no 129/130, 1993, p. 91. 
enumerando vocabulário da natureza presente na poesia do autor, assinala: "Mas - coisa notável - nunca se vê o céu», concluindo depois que «nenhuma impressáo de infinito, de largueza, de amplidão, vem arejar os seus poemas. $\mathrm{O}$ olhar de Pessanha não parece abranger a realidade em superfície, considerá-la de cima. O mar, de que tanto se fala na Clepsidra, raramente é olhado na extensão: mais fácil é perscrutar-se-lhe o fundo» ${ }^{16}$. Pena foi que a autora náo tenha considerado "Branco e Vermelho», onde, como veremos, o sujeito se alça a uma visão de sobre-voo.

Retornando à quadra de abertura, dá-se uma coloração masculina e voluntariosa ao eu, e um cariz feminino e passivo à alma ${ }^{17}$. $\mathrm{O}$ verme simboliza o lado destrutivo da libido, a sua regressão ao estádio inicial e informe ${ }^{18}$.

Ora, é justamente num estado pré-formal, pré-demiúrgico que se situa a poesia que fecha o livro. Cotejando "Inscrição» com o «Poema Final», o desejo de náo ser é transferido para entidades que se podem reunir sob o traço comum da potencialidade, numa escala que procede do menos para o mais animado, do subterrâneo para o aéreo: «cores virtuais», «abortos» e os «sonhos não sonhados». A todas elas é dirigido o apelo a não passarem a ser, a não exercerem actividades vitais, sensitivas e pensantes: cerrar as pálpebras, não velar, deixar de cogitar e sondar o abismo, adormecer, não suspirar, sequer respirar. Toda uma constelação de termos-símbolo, a luz, o tempo e o vento, é objecto de denegação. Voltaremos à análise deste poema. O que interessa é relevar como estes dois poemas assim aproximados podem dar a chave de leitura de todo o livro.

A mera inventariação, ordenada segundo a sequência dos poemas, da caracterização dessas figuras do «eu», dessas instâncias líricas tradicionais, prova à saciedade o tom saturniano da sua poesia.

A negatividade dessas figuras demonstra, segundo Rubim, uma retórica destrutiva dessas instâncias, dessas figuras da identidade

${ }^{16}$ Lemos, op. cit., p. 28.

${ }^{17}$ A alma "c'est l'affectivité inférieure, le subconscient, cet inconscient longuement refoulé, et pressé de reparaître au grand jour: monde des instincts, des rêves et des aspirations vagues», Guy Michaud, Méssage Poétique $d u$ Symbolisme, 2a ed., Paris, Nizet, 1966, p. 403, cit. in Cardoso Gomes, $A$ metáfora cósmica em Camilo Pessanha, p. 43.

18 «Le ver symbolise l'aspect d'abord destructeur de la libido (...) par rapport à l'organisation supérieur, il est régression ou phase initiale et larvaire», Jung, cit. in Cardoso Gomes, op. cit., p. 44. 
lírica e pessoal. Mas sob o nível retórico jaz o nível existencial, a dilaceração íntima, a dor. A ironia que se possa rastrear na poesia de Pessanha não é nunca lúdica, mas amarga. Por exemplo, o verso de «Madalena», "Ó redenção do mármore anatómico», o qual em rigor não se pode ligar com segurança ao sujeito ou a Madalena, embora nos inclinemos para o sujeito, pode ter algum ingrediente de humor, como aquele que arreganha em disfemismos populares designativos da morte («esticou o pernil», «está a fazer tijolo»). Se tem humor, trata-se de um humor autodepreciativo, ácido: o mármore lembra as estátuas, glorificaçóes marmóreas de deuses, reis, santos...mas este mármore é o do cadáver. Em «Tatuagens no meu peito", o autor joga com a nomenclatura majestosa da heráldica, intrometendo objectos irrisórios, kitsh: entre os nobres "Troféus, emblemas, dois leóes alados...» destoa uma grinalda de coraçóes e, sobretudo, "Um enorme, soberbo amor-perfeito...", quinquilharia simbólica vulgar, tornada grotesca pelos adjectivos. No seu brasão, tudo é curial na segunda quadra, mas o timbre, no terceto seguinte, em vez de ser uma coroa, como era convencional, é a rompante megalomania que contrasta com a divisa, antítese das sentenças valorosas e virtuosas convencionais: um ai derrotista, mais próprio para se associar a ruínas, a sepulturas rasas (que eram as dos mais pobres). Estes laivos de irrisão significam um rir amargo de si próprio, um auto-depreciamento burlesco. Um auto-retrato em que escarnece de si. Uma leve ironia, não dirigida a si, mas a um garboso e iludido soldado, se espraia ao longo do poema "Rufando, apressado», bem como em "Interrogação», onde volteia um certo dandismo.

$\mathrm{O}$ poeta, na verdade, nunca se ri desprendidamente de si próprio. A sua dor é real, tão real que o leva a sentenciar que «sem ela o coração é quase nada». A vontade de nada conceder à subjectividade e ao seu conteúdo lírico, de ver não o sujeito, mas a sua ausência, de afastar o espectro de qualquer sentido último, leva Rubim a estes contorcionismos dialécticos quando caracteriza a poética do trágico em Pessanha: «a dor náo é por isso um signo da experiência vivida como anterioridade do que se escreve na "página branca», mas antes uma marca dupla suspendendo a oposição entre a vida e a morte, ainda um signo de vida e já um sinal de morte» ${ }^{19}$. Noutros termos, a dor não preexiste como experiência vivida à apariçáo do signo, sendo uma sígnica coincidentia oppositorum de vida e morte. Mas falar de

\footnotetext{
${ }^{19}$ Rubim, A Inscrição Espectral..., p. 366.
} 
signo de vida e de morte não equivale à admissão de que o signo remete a um outro que não ele?

\section{1 - O coração}

Figura convencional do íntimo e do sentimento pessoal, instância lírica por excelência, o termo "coração» comparece em várias poesias de Clepsidra. Em "Caminho I», a dor é declarada a essência do coração; em "Olvido", a paz da morte aquieta "por fim» "o meu coração», extinguindo o desejo e a saudade; em "Madalena», é associado à metáfora in praesentia "velha moeda fútil», erodida pela resignação; é apostrofado no primeiro soneto do díptico "Paisagens de Inverno» a cessar o desejo, a submeterse à prudência da inacção; é caracterizado como "vazio» no segundo; «Na Cadeia», outra metáfora, «Estranha taça de venenos», fervilhando «sempre em revolta»; pretende expulsar o coração, lançá-lo ao mar, banhá-lo em água salgada em «Canção da Partida»; mais uma metáfora, «balão apagado», e outra, «átomo miserando» em "O meu coração desce»; o coração que não se prende à parlenda esmorecida da viola morosa em «Viola Chinesa», mas que reage a um acorde que lhe agita uma cicatriz secreta, melindrosa.

\section{2 - A alma}

Seleccionando os adjectivos caracterizadores da «alma» do sujeito, obtemos a seguinte série: «lânguida e inerme», "doente», "egoísta e fraca».

Esta recolha de citaçóes relativas ao "coração» e à "alma» invalida, à partida, a hipótese de reconhecer no «eu» lírico da poesia de Pessanha os contornos de um «espaço» interior, como aquele escavado pelos grandes românticos, donde a intuiçáo ou o sonho ou o sentimento abrissem para a Natureza, o Ser ou o Infinito. $\mathrm{Na}$ grande tempestade romântica, não obstante o seu excesso, o seu desequilíbrio (o mal-de-vivre, a insatisfação permanente, a Sehnsucht ...), em contraponto a uma sabedoria dos limites que subjaz, seja ao Classicismo, seja ao Iluminismo, predomina, afinal, a confiança ontológica: a procura do centro, que parte da sua ausência, de uma desproporção ôntica, originária da condição humana, centro reconhecido no moi romântico, através de demanda labiríntica, complicada pelas denegaçóes da ironia, recorta não um lugar geométrico, mas um lugar ontológico em que, através do sentimento (Gemüt) 
ou do sonho, operam a sua coalescência o homem e a Natureza (não a natureza morta que a técnica explora, não a do universo galilaico-newtoneano, que «est le vide du coeur», mas a Natureza viva e animada). $\mathrm{O}$ grande eixo romântico tende a ser um antropo-cosmologismo ${ }^{20}$.

Deste modo, os termos-chave do "coração» e da "alma» que o Romantismo concebeu, predominantemente, em termos inequivocamente positivos aparecem em Pessanha emurchecidos e inanes. O poeta-vidente, o poeta-auscultador do mistério do Cosmos, figuras que o Simbolismo recupera do Romantismo, desmultiplicando os seus significados, pressupóem, mais uma vez, uma confiança ontológica fundamental. Ora, parece que nada há a esperar do coração e da alma do «eu» lírico de Pessanha.

Passemos a considerar a caracterização dos «olhos» e cognatos na obra de Pessanha, verificando se prolongam a linha disfórica que articula «coração» e «alma».

\section{3 - Os olhos}

Metáfora praticamente universal do conhecimento intelectual (basta lembrar a centralidade da metáfora óptica na tradição filosófica ocidental: platonismo, cartesianismo, a fenomenologia husserliana) $)^{21}$, os «olhos» em Pessanha também revestem esse significado metafórico, descolando-se da imagem tradicional de olhos, janela da alma. Como observa Esther de Lemos, «interessa notar que estamos muito longe dos olhos «espelhos da alma» da poesia tradicional. Tomados em si mesmos ou em sentido figurado, os olhos são quase sempre veículo de conhecimento, reflectem de fora para dentro e náo de dentro para fora ${ }^{22}$. Este «quase sempre» ressalva os casos em que os olhos reflectem bem mais o "dentro» do que o "fora», por exemplo, "os olhos incendidos que o pecado/ queimou», de «Paisagens de Inverno I» ou os «olhos ardidos, / Nos quais a chama do furor declina...» do soneto «Desce em folhedos tenros a colina».

${ }^{20}$ Cf. os cap. «Quête du Centre et Anthropologie Négative» e «Situation de l'Homme dans la Nature: Anthropocosmomorphisme», in Georges Gusdorf, L'Homme Romantique, Paris, Ed. Payot, 1984, pp. 62-75 e pp. 153-180.

${ }^{21}$ Sobre a centralidade da metáfora do olhar na tradição filosófica, registese a constatação de Maria Zambrano em "A Metáfora do Coração", in $A$ Metáfora do coração e outros Escritos, Lisboa, Assírio \& Alvim, 1993, p. 19 - «a Filosofia mais pura desenvolveu-se no espaço traçado por uma metáfora, a da visão e da luz inteligível».

${ }^{22}$ Esther de Lemos, op. cit., p. 57. 
Dividindo muito arbitrariamente a caracterização dos «olhos do poeta» da dos olhos dos outros, suspendendo a interrelação que entre eles haja, temos: do lado do sujeito, "meus olhos... cansados», "meus olhos incendidos que o pecado queimou», "ó meus olhos, cismai como os velhinhos», "O meu olhar cansado", "meus olhos ardidos», "meus olhos baços», "olhos turvos de lágrimas contidas», "O espelho inútil, meus olhos pagãos! Aridez de sucessivos desertos...», «olhos apagados», «cansados de ver»... Do lado dos outros, "o teu olhar sem cor, - frio escalpelo», "os seus olhos abertos e cismando», "teus olhos como vão tristes», os «olhos» dos «mortos da batalha» «abertos/ reflectindo as estrelas, boquiabertos...», o "teu olhar suave», os "olhos acesos» dos bandidos que a prisão mudou em "olhos cativos», os «ímpetos de fera/ Nos olhos» da «torva ralé»...

Deste inventário se infere que o olhar acaba por ser fonte de dor. Daí o apelo ao cerrar das pálpebras, ao vedar do principal vaso comunicante entre o dentro e o fora: do lado do sujeito, «-Sorrindo interiormente/ Coas pálpebras cerradas»; do lado do objecto, "Ó cores virtuais (...) As pálpebras cerrai, ansiosas não veleis».

\section{2 - SOBRE O SENTIMENTO}

A abordagem às figuras da instância lírica tem, inevitavelmente, de tanger a categoria do sentimento, mola fundamental da criação poética, segundo o Romantismo. Dada a explícita recusa da plangência romântica, dados também os acentos negativos que "coração» e "alma» recebem, seríamos levados a rejeitar à partida esta categoria como instrumento hermenêutico válido da poesia de Pessanha. Porém, esta objecção é legítima se conferirmos ao sentimento uma acepçáo inteiramente subjectiva e se, inadvertidamente, o ante-valorizarmos num sentido positivo.

Vivência afectiva, o sentimento contém uma intencionalidade. O sentimento é sempre sentimento de algo, sentir o amável, o odiável, etc. Aplicando o esquema husserliano noesis/ noema, o sentimento comporta intimidade e intencionalidade. No acto de sentir, deflagra a consciência imediata, sem intermediários, das coisas e de nós mesmos. Ao visar qualidades sentidas «sobre» coisas ou pessoas, o sentimento revela ao mesmo tempo o modo como o eu é impressionado ou afectado. Por exemplo, no fugir das águas do rio, em "Paisagens de Inverno II», o sujeito projecta a corrente dispersiva e vã das melancolias do seu coração vazio. 
Os correlatos do sentimento, os seus «objectos», são sobretudo qualidades que necessitam do suporte de uma coisa exterior ou de uma pessoa para se "objectivar». Radica aqui, no seu vector intencional, a capacidade do sentimento de se enunciar e de se comunicar. Como tal, o sentimento é também conhecimento, intuitivo, confuso, não representativo, na acepção de pré-lógico ou antecategorial, se entendermos como condição do conhecimento representativo a dualidade clara entre sujeito e objecto, entre a esfera do sujeito e a do objecto, a clarté cartesiana A categoria do sentimento pertenceria mais ao originário, provavelmente ao pré-discursivo, enquanto a intelecção, o conhecimento lógico, à ordem do derivado, enquanto posição e discurso de segundo nível.

Todas as filosofias ditas reflexivas póem que a instauração da reflexão interrompe o curso do vivido, do experienciado, esclarecendo, destacando, separando, num momento segundo, uma "matéria» que lhe preexiste. No sentimento, é na mesma vivência que coisas ou pessoas objectivam o amável ou o odiável e que simultaneamente estes expressam sobre as coisas ou pessoas o meu amor ou o meu ódio. Noutros termos, sentir é experimentar um sentimento como um estado de alma $e$ como a propriedade de um objecto.

Contudo, reconhecer uma componente cognoscitiva no sentimento implica superar a oposição estabelecida pelo Positivismo entre os campos do cognitivo e do emocional. De facto, o Positivismo Lógico do Círculo de Viena elegia a linguagem científica como a única verdadeiramente factual e real (pois só as proposiçóes científicas se podem submeter ao critério da verificabilidade, que se torna $o$ critério da adequatio, da verdade), retirando deste princípio que os enunciados que não descrevem factos não são denotativos, mas emotivos ou metafísicos. Segue-se, então, que o que é emocional ocorre dentro do sujeito, é meramente subjectivo, não se relacionando, mensurável e descritivamente, com qualquer coisa fora, exterior ao sujeito. Segundo Carnap, «o objectivo do poema no qual surgem as palavras raios de sol e nuvem não é o de nos informar sobre factos meteorológicos, mas o de exprimir certas emoçóes do poeta e o de suscitar em nós emoçôes análogas». Contudo, reconhece que em poesia a emoção é «tomada na conta do objecto» ${ }^{23}$.

${ }^{23}$ Cit. in Ricoeur, Metáfora Viva, p. 339. 
Quem diz então que a emoção nada tem a ver com a realidade?

Náo sendo exclusivamente interior ao sujeito, a emoção (entendida como termo similar ao sentimento, conquanto um Max Sheller os distinga - a emoção é súbita, o sentimento mais durável, podendo este, a vergonha, por exemplo, comportar as manifestaçóes mais variáveis, o empalidecer e o corar, dobras do mesmo leque) não é puramente subjectiva, participa do "objecto", dá indiscernivelmente a coisa e o eu. Considere-se, a este propósito, a impressão de viagem transmitida em carta endereçada a Carlos Amaro: «Outra coisa que não me lembro de ter visto anteriormente: são os arco-íris, múltiplos e móveis, que em certas ocasiōes aparecem correndo, ao longo de cada uma das ondas que vêm quebrar-se de encontro ao vapor. Delicioso e efémero efeito de luz, tão agradável para repouso dos olhos e da melancolia. Quem fosse capaz de o fixar em dois versos transparentes!...» ${ }^{24}$. Além da inequívoca concessão à mimesis da poesia ${ }^{25}$, importa observar que os hipotéticos versos que se referissem a esse "efeito de luz» não visariam um simples facto meteorológico, mas uma luz nimbada de delícia, efemeridade e agradabilidade. $\mathrm{O}$ espaço do sentimento não é o espaço neutro, incolor e homogéneo das ciências físicas. $\mathrm{O}$ adjectivo "efémero» não designa apenas a mensurável durabilidade reduzida do fenómeno atmosférico, mas sugere a evanescência da felicidade e da beleza, sentida pelo sujeito e objectivada simultaneamente nesse efeito de luz. Os sentimentos de alívio, de tréguas dadas à melancolia, são perspectivados como consequência de uma qualidade inerente a esse efeito de luz.

Assim, no sentimento, estão imbricados sujeito e objecto, a coloração é da "alma» e também da coisa. Pode esta concepção de sentimento servir de fio condutor para tratar da problemática do conhecimento na poesia de Pessanha? Em algumas poesias de Clepsidra deparamos com um caleidoscópio de imagens, dados sensoriais, fragmentos de realidade, sobreposição de planos temporais (maxime, "Chorai Arcadas do Violoncelo»), mas ligados, unidos pelo poder da analogia, no qual, segundo Ester de

${ }^{24}$ Pessanha, Contos, Crónicas, Cartas escolbidas..., p. 96.

${ }^{25}$ Este suspiro "mimético» de Pessanha situa-se nos antípodas da teoria que defende que «os poemas não são transparentes em relação a uma realidade que dariam a ver e cuja visão fizesse esquecer a própria «superfície dos poemas» (como se esquece o vidro de uma janela).», Rubim, A Inscrição Espectral..., p. 17. 
Lemos, o raciocínio não intervém, apenas a intuição associativa. Será uma intuição, guiada menos pelo intelecto, que separa, do que pelo sentimento que mistura o subjectivo com o objectivo.

Referimos «amor» e «ódio» e os seus correlatos, o «amável» e o "odiável». Serão sentimentos demasiado veementes para a persona poética de Pessanha. Situam-se na ordem do elementar, do "pathos» mais ebuliente. Amor, ódio, alegria e pena constituíam as Stimmungen, as disposiçóes afectivas fundamentais que, segundo Carl Gustav Carus ${ }^{26}$, pensador romântico alemão, estruturavam a vida emotiva de cada indivíduo. Ora, esse termo é indissociável de Gemüt, palavra-chave do Romantismo alemão, cuja tradução mais aproximada em português será «sentimento». Tínhamos reportado o ponto de vista de Carnap, prócere do Neo-Positivismo, ramificação, podemos afirmá-lo, do espírito das Luzes, de que o Romantismo se demarcara. A antropologia iluminista via o homem essencialmente como razão, sob a luz da qual seriam finalmente vencidas as trevas da ignorância e da superstição (com Newton, nascia a luz, quer dizer, a ciência, guia seguro do "progresso»). Opostamente, o Romantismo reabilita, como se sabe, a paixão, o sentimento, o sonho, invertendo a ordem da prioridade: o mais importante e o mais humano são aquilo que à razão (Verstand) escapa. Assim, um esboço da problemática do «sentimento" tem a fortiori que remeter ao homem romântico, que volta a lavrar a "alma», «em pousio, depois de quase dois séculos de razão ${ }^{27}$.

\section{1 - Gemüt e Stimmung, a «verdade» romântica}

Como a nossa palavra «saudade», Gemüt é declarada intraduzível para o francês por Heine. Gusdorf acrescenta a sua imprecisão em alemáo, o que permite conjecturar que nada garante que «o utilizador do termo Gemüt saiba, no momento em que o escreve, o que este quer dizer ${ }^{28}$. Náo por acaso, a nascente deste termo encontra-se nas congeminações de místicos como Mestre Eckhart e, depois, Jacob Boehme, que o elegem como o princípio comum das faculdades espirituais e afectivas. A era romântica alargará o leque de significados do termo, mantendo esta ideia de que o Gemüt é a fonte comum do desejo, da afectividade e do

${ }^{26}$ Cf. Georges Gusdorf, L'Homme Romantique, p. 97.

${ }^{27}$ Maria Zambrano, "Rumo a um Saber sobre a Alma», in A Metáfora do Coraçâo e outros Escritos, p. 30.

${ }^{28}$ Georges Gusdorf, op. cit., p. 89. 
sentimento. Para Frédéric Schlegel, radica no Gemüt a origem da força vital da beleza e o «instinto da grandeza moral». Atribui-lhe um cunho feminino, quando declara que a beleza das mulheres está ligada à faculdade de amar. Schleiermacher póe o Gemüt como condiçáo do mundo espiritual ${ }^{29}$, e na origem da capacidade de simpatia que reconhece a humanidade do outro.

Hemsterhuis descobre no Gemüt o senso íntimo, o órgão que apreende os valores afectivos e emotivos como atestaçóes da Transcendência divina. Deus não se oferece ao entendimento, mas ao homem de sentimento e de desejo.

Novalis, por seu turno, vê nele o fundo que unifica os elementos mais diversos da intimidade e que apreende o mundo numa geometria colorida pelas contribuições da imaginação e da afectividade. Daí que, no fim de contas, «tudo devém poesia. $\mathrm{O}$ mundo não é finalmente Gemüt?»» ${ }^{30}$. A poesia consiste em pô-lo em movimento, é a sua representação, isto é, o mundo interior na sua totalidade. $\mathrm{O}$ idealismo mágico de Novalis sobrepóe o ideal ao real, operação efectuada pelo Gemüt que se expande no cosmos.

Schlegel insiste no seu valor ontológico de presença no mundo, de inserção no universo. Se o Gemüt é poesia, e a poesia é Gemüt, deflagra, como dirá Maria Zambrano, a «perigosa e encantadora confluência» entre "a natureza, no que tem de irredutível a fórmulas matemáticas, e a alma humana, no que tem de estranha às luzes da razão. As tempestades, os naufrágios, as ondas alterosas, os terríveis abismos eram naturais e humanos ao mesmo tempo, eram natureza e alma, eram cósmicos...» ${ }^{31}$. O contrapólo do Gemüt é o entendimento (Verstand), a razão matematizante. É óbvio que estas polaridades podem-se desfazer criando a sua ordem de verdade específica, hierarquizando-as. $\mathrm{O}$ ponto está no primado: as razões do coração ou as razôes da razão? Qual o verdadeiro a priori, a lógica pura, o eu transcendental kantiano, ou a lógica do coeur, cujos axiomas são axiológicos, donde provêm as orientaçóes maiores da existência?

$\mathrm{O}$ Gemüt como englobante das potências do eu e faculdade de orientação ontológica liga-se estreitamente a outro termo, Stimmung, que designa o acordo da alma consigo própria - «uma

${ }^{29}$ "...sans fantasie il n’y a pas de monde extérieur, de même, em dépit de tous les sens, il n'y a pas, sans Gemüt, de monde spirituel», cit. in Gusdorf, op. cit., p. 93.

${ }^{30}$ Cit. in Gusdorf, op. cit., p. 94.

31 Zambrano, op. cit., pp. 30, 31. 
acústica da alma», na expressão de Novalis - e da alma com o mundo. Um ideal de harmonia estética e moral, portanto, mas que não procede de uma conquista, de um esforço de obtenção de um equilíbrio, mas de um dom, uma graça. A metáfora que lhe convém é a da música: todas as vozes da alma em estado de Stimmung vibrariam em harmonia com o canto do cosmos. Não se trata de uma emoçáo, uma harmonia meramente intra-subjectiva, mas de uma relação com o mundo, que quer dizer logo harmonia do homem com a paisagem: os grandes poetas românticos ingleses encaram a alma do poeta como o lugar de comutaçóes graças às quais a paisagem se torna consciente e a consciência se torna em mundo. $\mathrm{O}$ conhecimento poético é co-nascimento, ocasião de renovo da antiga aliança entre homem e cosmos, segundo o original projecto divino $^{32}$. Charles du Bos equaciona assim a relação entre Gemüt e Stimmung: "A Stimmung é um dos efeitos de uma causa mais vasta ainda: o Gemüt, termo náo menos intraduzível que, segundo os casos, designa a alma, o coração ou o sentimento no que eles têm ao mesmo tempo de mais amplo e de mais indivisível ${ }^{33}$. Acrescenta que esses termos estão na base das noçóes fundamentais de Novalis: a do eu mágico e a da poesia absoluta.

Esta incursão pelas elucubraçóes românticas carreará focos pertinentes para a análise da poesia de Pessanha? Além da sugestão da música como canal privilegiado de uma harmonia entre eu e não eu (tópico que o Simbolismo expande e que se pode rastrear, nomeadamente, na flauta grácil que chora na escuridão tranquila), poucas ou nenhumas aproximações se podem efectuar entre estes conceitos e o universo bem menos cálido e esperançoso da poesia de Pessanha. Amiel afirmava que cada alma tem o seu clima e é um clima. Mantendo com os românticos a significação cósmica do sentimento, o seu alcance cognoscitivo, passaremos a considerar outro tipo de sentimentos prevalecentes no clima da alma de Pessanha, privados da harmonia, da Stimmung...

Pois, não são a angústia, a languidez, o tédio ou o desespero sentimentos? Se admitirmos a intencionalidade constitutiva do sentimento, o que dizem do mundo os últimos sentimentos enumerados? É óbvio que nesta linha há que ultrapassar a frequente ideia que vê no sentimento uma reserva de energia e de generosidade e que não estava ausente nos arrazoados românticos que referimos acima. É que o sentimento pode levar não só à

${ }^{32}$ Cf. Gusdorf, op. cit., p. 106.

${ }^{33}$ Ibidem, p. 98. 
acção, concreta e positiva, mas também à fuga - "Oh, quem pudesse deslizar sem ruído!».

No discurso filosófico, desde Kierkegaard, que esses sentimentos têm sido explorados como via de acesso às estruturas fundamentais do humano ser-no-mundo. Em Heidegger, por exemplo, na sua primeira fase, a angústia é a situação emotiva, o estado, que coloca o homem perante o nada, por, ao contrário do medo, não ter causa concreta e definível (ter medo é sempre ter medo de), sendo assim de origem indeterminada, uma ameaça que cai sobre a totalidade da minha existência. É a marca distintiva da existência autêntica que se prova ao manter-se firme no interior do nada, ao encarar, compreendendo, essa possibilidade da impossibilidade que é o ser-para-a-morte. $\mathrm{O}$ ser humano, o Dasein, pensa, ou melhor, espera a morte por antecipação (para-a), e essa angústia e essa solidão resgatam-no da dispersão da existência inautêntica. $\mathrm{O}$ último terceto de "Desce por fim sobre o meu coração" ilustra perfeitamente esse cunho indefinido ou indeterminado da angústia: «las andar, sempre fugia o chão,/ Até que desvairavas, do terror./ Corria-te um suor, de inquietação...». Este desassossego, este terror súbito de perder o pé não é vinculado a nenhuma causa, traduz uma insegurança inerente ao mero "andar», ao simples existir. Mas ficam por aqui as similitudes entre as categorias filosóficas do pensador alemão e a poesia do português. Para Heidegger, o nada que a angústia e a morte revelam é o véu do ser e a liberdade para-a-morte requer uma tensão, um esforço heróico. Ora, Pessanha quer «afugentar bem rudemente» a dor do seu coração, anestesiá-la e o véu do nada da morte não esconde senão o nada.

A vida como soçobramento, naufrágio, adiado ou desejado, lembra a fórmula de outro filósofo contemporâneo de Heidegger, a existência como ser-para-o-naufrágio ${ }^{34}$. Mas Jaspers vê no fracasso, na experiência do fracasso, a revelação da insuficiência do intra-mundano (no falhanço, percebemos que o mundo não é tudo, o que permite dar o "salto»), a cifra por excelência que medeia a existência e a Transcendência. Jaspers, a seu modo, pode ser considerado um filósofo simbolista no sentido em que o espírito humano conhece (embora não ao nível do

${ }^{34}$ É Lélia Maria Parreira Duarte que refere esta fórmula de Karl Jaspers em «Literatura/ Escritura e um poema de Camilo Pessanha», in «Suplemento Literário", Minas Gerais, Belo Horizonte, 1977, apud Christine Pâris-Montech, op. cit., p. 227. 
entendimento, mas através da «fé» filosófica... o que lembra o conhecimento transracional e analógico advogado por alguns poetas simbolistas) cifras ou símbolos que constituem uma linguagem da Transcendência, que, contudo, é o que está sempre para além do que é pensável ou experimentável, não possuindo os atributos tradicionais de Deus, como a Providência. Ora a Transcendência, com maiúscula, está ausente em Pessanha. Se Jaspers conhecesse o fracasso de Pessanha diria, talvez, que não era "autêntico", porque despoleta a paixão da noite, o nihilismo, em vez de elevar do intra-mundano.

Reconhece-se este vocabulário filosófico de cariz existencial na afirmação de Óscar Lopes de que "a intuição fina de Pessanha", evitando a lava efusiva do derrame sentimental, apura «as relaçóes essenciais do nosso estar no mundo» ${ }^{35}$. Um estar-no-mundo precário, sempre na borda do abismo, em risco de naufrágio.

Elegendo a categoria do sentimento como fio condutor da análise da poesia de Pessanha, ressalvando desde logo que de "sentimento» não se deve inferir «sentimental», o mais óbvio dos sentimentos a tratar é o «amor». Um dos traços reconhecidos ao Gemüt era a capacidade de empatia como o outro ser humano. Verificaremos se essa direcçáo marca o amor na poesia de Pessanha.

Já tínhamos referido que para Óscar Lopes o amor em «Interrogação» era do tipo simbolista, pois não era vinculado a uma pessoa concreta. De facto, com excepção do poema «Se medito no desejo que promete» (escrito aos dezoito anos e recheado de clichés exóticos então muito em voga), nos poemas que se podem enquadrar na temática amorosa, a amada (o destinatário intratextual) é sempre vaga, não é desenhada por traços descritivos precisos ${ }^{36}$, mas captada por um ou outro aspecto, sob um enquadramento simbólico (Vénus, sílfide...). É, de facto, nesse poema que aparecem versos assinalando contornos precisos: "A sua boca fresca, pequenina,/ E o seio mergulhado em renda fina,/ Sob a curva ligeira do corpete;». Esther de Lemos nota o kitsch das imagens engastadas, nomeadamente na terceira estrofe onde o acto de posse da amada é comparado ao estorcer-se espiralado da serpente nos troncos de "palmeiras colossais». Judiciosamente, insiste que estas alusôes exóticas, em

${ }^{35}$ Lopes, «Pessanha: o quebrar dos espelhos», p. 199.

${ }^{36}$ Mais esboços do que retratos. Cf. «Os seus (ia escrever «retratos» mas sinto que é impossível usar semelhante palavra), os seus esboços, digamos de mulheres, (...)», Esther de Lemos, op. cit., p. 64. 
especial a referência aos opiómanos chineses, afloram aos dezoito anos e não retornam mais. Alude a uma imagem convencional da China quando talvez nem sequer pensasse em ir para Macau ${ }^{37}$. Vivendo longos anos em contacto quotidiano com os hábitos e cultura chineses, não mais os refere na sua poesia. $\mathrm{O}$ aspecto da cultura chinesa que interessou e fascinou Pessanha foi a arte, pintura e poesia. De tudo o mais, Pessanha sofre do complexo de Kipling, da evidência do "fardo do homem branco» em levar a civilização aos bárbaros, amarelos e outros. Pessanha era, de facto, um eurocêntrico, expressão muito difundida hoje em dia, transformada em labéu. Se algumas dúvidas houvesse, bastaria reparar do diagnóstico severo, caliginoso, que traça da civilização chinesa, já referido anteriormente ${ }^{38}$.

\section{3 - AMOR, COMPANHEIRISMO E CONHECIMENTO INTERSUBJECTIVO}

A poesia que talvez melhor ilustre a inadequação entre desejo e realidade seja «Se andava no jardim».

A indefinição da amada é logo dada pela condicional do primeiro verso. Não é inteiramente certo que quem ande no jardim seja ela e não o próprio sujeito. Dela se conhece apenas o halo, pois é "tão branca do luar». Este traço vaporoso concorda com o modo pelo qual o sujeito a desejou - pelo sonho - «Após tanto a sonhar...». O terceto de reticências como que encobre pudicamente o processo de conquista. Este último termo é congruente com o termo "vencida» e com a intensidade investida («Após tanto a sonhar...»).

Mas a posse não arrasta a felicidade esperada pois não teria sentido a pergunta "Porque entristeço assim?». Sem embargo, é dada uma razão: o que ele afinal queria abraçar (note-se a carga volitiva do verbo) não era ela, mas sim «A hora do jardim.../O aroma de jasmim.../A onda do luar...». Não reviver ou retornar ao primeiro encantamento amoroso, ao instante em que desejou a mulher feericamente nimbada pela luz do luar e que a posse destruiu, mas unir-se ao englobante, de que se exclui a mulher.

${ }^{37}$ Cf. Lemos, op. cit., pp. 24-26.

${ }^{38}$ Sobre o significado do exotismo na vida e obra do poeta, vide Seabra Pereira, História Crítica..., pp. 134, 135. Pessanha, no texto «Macau e a gruta de Camôes», declara que sáo prosadores aqueles que se deixam atrair pelo pinturesco do exotismo, não os poetas que cismam no exílio. A maneira de poetar de Pessanha, não discursiva, não oratória, teria recebido uma confirmação e um incentivo nas características peculiares da escrita e poesia chinesas, de cariz icónico, desarticulado... 
Esta não fixação num ser concreto, o deslocamento para o ambiente circunstante que parece importar mais do que o encontro, o face-a-face, sáo atitudes que atravessam um dos seus primeiros poemas, "Crepuscular».

Significativamente, a referência à reciprocidade entre sujeito e amada surge intercalada na descrição de um «ambiente» crepuscular. Não é uma paisagem que é descrita, nada há de fotográfico, de moldura firme, antes uma amálgama de sensaçôes lânguidas, auditivas e olfactivas, sem qualquer visualismo.

É importante notar que neste poema ocorre reciprocidade (rara) entre um eu e um tu. Enlaçam-se as máos e os olhares encontram-se, como que se fundem - «O meu olhar no teu olhar suave» - o verso é averbal, sugerindo uma sim-patia efectiva. Está aqui tocada ao de leve a ideia de mutualidade, da permuta interpessoal, de um bem-querer mútuo. Contudo, a relação é melancólica, provavelmente tão anémica como as mão pequenas da mulher, tão triste quanto os seus meigos olhos. O par de versos finais podem ser lidos como se fossem uma concessão, uma desculpa, como quem diz - «Deixa lá, a tua tristeza deve-se apenas ao vago sofrer do ocaso, amanhã será melhor».

Também no soneto, "Eis quanto resta do idílio acabado", pressupóe-se uma relação amorosa correspondida, mas que a morte aniquilou. A sua felicidade, de «um momento» embora, é sugerida pelo termo pastoril «idílio», pela sua metáfora «Primavera» que é reforçada pela colorida beleza das «amigas flores», "Anémonas, hidrângeas,/ Silindras», pelo espaço em que idílio e flores desabrocharam - o "alegre conventinho abandonado», cujo diminutivo ressuma ternura, e pelos epítetos da inscrição tumular, na invocação final: «Ó doce, ingénua, inscrição tumular.».

«Doce e ingénua» seria a amada e doce e ingénuo o idílio. Mas foi fugaz a felicidade, e é esta efemeridade que conta; a felicidade não é recuperada ou revivida pela recordação, os olhos estão cansados: é o que o primeiro dos versos destaca - «Eis quanto resta do idílio acabado» - o nome tumular da amada a esbater-se, entrevisto por entre «urtigas» e "cobras» serpenteando por entre as ruínas do claustro.

Noutro poema, «Floriram por engano, as rosas bravas», como em «Crepuscular», são dadas as mãos, e os olhares encontram-se, mas a reciprocidade é mais ténue: são duas solidóes que se tocam o seu andar de mãos dadas não tem norte, o pensamento é alheio, náo se fixa no outro e o olhar da amada perscruta o dele, mas apenas 
por um momento e ensopado de tristeza («como vão tristes!»).

Nos dois últimos versos da quadra anterior, esboça-se um diálogo - «em que cismas, meu bem, porque me calas as vozes com que há pouco me enganavas?». As vozes, as palavras da amada seriam, deste modo, sedutoramente enganosas (repare-se no paralelo entre o florir "por engano" das rosas bravas e as vozes enganadoras, bem como o Inverno da primeira quadra e a acrópole de gelos do primeiro terceto). O que a teria feito calar e imobilizar-se na cisma? Eram essas vozes, por enganosas, castelos doidos fadados a desfazerem-se e o súbito silêncio a consciência do desengano? Teria sido a irrupção em meio do Inverno das rosas bravas e o seu desfolhar pelo vento que teria suscitado na amada a percepção de que o seu amor é tão passageiro como a floração das rosas, ou este desabrochar prematuro ter-lhe-ia despertado a recordação da juventude que se foi, e daí a profunda tristeza dos seus olhos?

Esse debuxo de drama, de complicação sentimental é interrompido, sem que se perceba com nitidez qual a relação, pelo esparzir abundante e «triunfal» da neve. As pétalas que o vento desfolhara retornam sob a forma de flocos de neve? A neve é nupcial, triunfal, generosa («quanta flor») «juncando o chão, na acrópole de gelos», tudo envolvendo, em apoteose de brancura e beleza. Formavam os dois um casal de cabelos brancos, é a acrópole o espaço em que a nupcial neve abençoa uma uniáo finalmente realizada? Estas conjecturas esperançosas esbarram com a simbologia negativa de neve e sobretudo de gelo.

Com efeito, em «Soneto de Gelo», é tematizado o derruir das crenças de oiro da religião tradicional, inculcada na infância, e a desolação, o "gelo» que a sua perda provoca. A neve e o gelo da acrópole (parte mais elevada das cidades gregas que aqui pode indicar o termo da subida do percurso vital) podem simbolizar o esfriar dos afectos, a velhice e a proximidade da morte.

A ausência de reciprocidade é atribuída à frieza inacessível da mulher em «Estátua». Não estamos em presença, neste soneto, da maneira típica do poeta: o estilo é discursivo, as frases assertivas, o poema desdobra, logicamente, um tema que era então um lugar-comum, muito cultivado pelo Parnasianismo, o da mulher fria e inacessível ${ }^{39}$, contendo o último terceto um

${ }^{39}$ Este tema sustenta o poemeto «Madrigal», muito menos denso, de tom leve e jocoso e onde também se insinua a presença da morte: «Aquela enorme 
remate sonoro, incisivo, não escapando também à hipérbole romântica («degredo...obsessão, pesadelo, noites de pavor, cheio de medo...»). Cidadela inexpugnável, nem o olhar, ou a alma ou o «lábio» respondem à ânsia ardente do poeta de correspondência ou de comunicação.

Verifica-se da primeira para a segunda quadra uma metamorfose dessa ânsia que muda de um olhar insistente («No teu olhar sem cor ...O meu olhar quebrei, a debatê-lo») para um oscular, num ambiente onírico, de pesadelo e terror. E no "pesadelo» a mulher petrifica-se, e o seu «lábio gelado» é um lábio de estátua, "de mármore», "severo como um túmulo fechado», como se o ósculo "alucinado» tocasse uma estátua mortuária. A fascinação que esta mulher ou, melhor, este tipo de mulher exerce no sujeito (o indecifrável "segredo dessa alma» constitui simultaneamente o «degredo» e a «obsessão» do poeta) radicará por último na corporização da morte (mulher-estátua, mulher de pedra).

Um ardor ainda mais intenso vibra no soneto "Esvelta surge». Mas este frémito sucessivamente erótico e guerreiro tem como diástole o soneto anterior em que «a chama do furor declina». Não por acaso, a terceira edição (1969) de João de Castro Osório inverteu esta ordem. Lidos à luz desta reordenação, do primeiro para o segundo soneto como que se descreve uma curva térmica descendente, um abrandamento em que o objecto do desejo se desmaterializa, se espiritualiza. Este esbatimento do "furor» que se opera de um para o outro soneto está perfeitamente em ordem com a teoria do desejo de cariz schopenhaueriano (o desejo acarreta inevitavelmente frustração e sofrimento, por consequência é sábio extingui-lo), enunciada explicitamente por Pessanha, já anteriormente referida. Assim, a decisão deste leitor (real) que se propóe interpretar conjuntamente os dois sonetos, iluminando-os reciprocamente, funda-se na filosofia do desejo explicitamente propugnada pelo escritor.

frieza/ Não entristeça ninguém.../ Ela estende o seu desdém/ À sua própria beleza: Quando, solta do vestido,/ Sai da frescura do banho, /O seu cabelo castanho,/ Esse cabelo comprido, (Que frio, que desconsolo!)/ Deixa ficar-se pendente,/ Em vez de, feito em serpente,/ Ir enroscar-se-lhe no colo!». Mas talvez a "serpente» tenha mais uma conotação sexual do que a de medusa ou de morte. Confrontem-se estes desenhos de mulheres altivas e fortes com a femme fragile Águia de Prata, concubina macaense do escritor, assim descrita - "pobre alminha ténue, toda a esvair-se em olor!», Carta a Trindade Coelho, datada de Macau, Abril, 8 (domingo de Páscoa), 1917, in Pessanha, Contos, Crónicas, Cartas escolhidas..., p. 113. 
Esvelta surge! Vem das águas, nua,

Timonando uma concha alvinitente!

Os rins flexiveis e o seio fremente...

Morre-me a boca por beijar a tua.

Sem vil pudor! Do que há que ter vergonha?

Eis-me formoso, moço e casto, forte.

Tão branco o peito! - para o expor à Morte...

Mas que ora - a infame! - não se te anteponha.

A hidra torpe! ... Que a estrangulo ... Esmago-a

De encontro à rocha onde a cabeça te há-de,

Com os cabelos escorrendo água,

Ir inclinar-se, desmaiar de amor,

Sob o fervor da minha virgindade

E o meu pulso de jovem gladiador.

Desce em folhedos tenros a colina:

- Em glaucos, frouxos tons adormecidos,

Que saram, frescos, meus olhos ardidos,

Nos quais a chama do furor declina...

Oh vem, de branco, - do imo da folhagem!

Os ramos, leve, a tua mão aparte.

Oh veml Meus olhos querem desposar-te,

Reflectir-te virgem a serena imagem.

Da silva doida uma haste esquiva

Quão delicada te osculou num dedo

Com um aljôfar cor-de-rosa viva! ...

Ligeira a saia ... Doce brisa, impele-a

Oh vem! De branco! Do imo do arvoredo!

Alma de silfo, carne de camélia...

Os sonetos contrastam no cenário, no tipo de mulher e na postura do sujeito. É marítimo no primeiro, campestre e bucólico no segundo. A mulher, de Vénus, transfigura-se em sílfide. Ao desejo ardente, imperioso, sucede um apelo suavíssimo, uma súplica doce.

Cenário, mulher e modalidade do desejo harmonizam-se perfeitamente. Na verdade, a primeira quadra do primeiro soneto 
constitui uma descrição de Vénus, enquanto, no segundo, só na segunda quadra é que são introduzidos alguns, leves, traços da mulher. Ambas surgem em movimento, Vénus timonando uma concha, a sílfide impelida pela brisa (se no primeiro verso o sujeito gramatical é "colina», dada a ambiguidade cultivada pelo poeta em que palavras e versos se cooptam, pode-se supor como sujeito subentendido a sílfide e "a colina» como complemento directo). Neste pressuposto, a unidade com a paisagem é sublinhada pela preposição em folhedos tenros, em vez da mais lógica por.

A primeira nota de Vénus é "esvelta» ${ }^{40}$, enquanto a da sílfide é "de branco». Uma nota sensual versus uma nota espiritualizante.

A Vénus «surge» de chofre num espaço aberto, inteira. A sílfide aparece paulatinamente, rodeada pelo misterioso chiaro-oscuro do arvoredo, afagada pela blandícia dos tenros folhedos (o arranhão da silva é um ósculo...), levada, acariciada pela doce brisa. É a essência feminina dimanada da verdura aprazível e bucólica, «do imo da folhagem», «do imo do arvoredo».

Diversamente, Vénus emerge das águas do mar ( Vem das águas, nua»), ressumbrando sensualidade («os rins flexíveis e o seio fremente...»), concitando as vagas do desejo carnal («morre-me a boca por beijar a tua.»).

As atitudes do sujeito são diametralmente opostas. Irrompe enérgico, decidido, pujante de força - «Eis-me formoso, moço e casto, forte.» - quebrando as barreiras do «vil pudor» e da «vergonha», certo de a fazer «desmaiar de amor» sob o seu másculo amplexo, pelo vigor do seu «pulso de jovem gladiador» ${ }^{41}$. O que

${ }^{40}$ Mário Garcia, em «Sobre Camilo Pessanha», in Brotéria, Vol. 122, No 4, Abril 1986, p. 388, assinala o slancio que Barbara Spaggiari descobre no $v$ (em vez do b) deste adjectivo, contribuindo para o frisson sensual do seu surgimento

${ }_{41}$ No poema, já referido, «Se medito no gozo que promete», ferve sem rebuço o desejo físico: «Desejo, nuns transportes de gigante, / Estreitá-la de rijo entre meus braços, / Até quase esmagar nestes abraços/ A sua carne branca e palpitante;»; mas com laivos de morte, como se depreende, mais que do verbo "esmagar», da invocação da serpente no símile desenvolvido na terceira quadra. Talvez seja digno de nota constatar que este poema inaugural oscila entre a atracção pelo amor erótico e pelo amor, à falta de melhor palavra, narcotizante, esvaído em devaneio semi-hipnótico e aconchegante: «Eu quisera também, adormecido, / Dos fantasmas da febre ver o mar,/ Mas sempre sob o azul do seu olhar,/ Envolto no calor do seu vestido; Como os ébrios chineses delirantes/ Aspiram, já dormindo, o fumo quieto/ Que o seu longo cachimbo predilecto/ No ambiente espalhava pouco antes...». Neste símile final, subentende-se que o ardor sensual das três quadras iniciais é assimilado ao estado de hiperexcitação causado pela droga, e que, ao expressar 
torna este soneto enigmático é a intromissão da morte-hidra, que sem ela constituiria uma celebração gaia do amor físico. Parece que Pessanha não consegue abstrair nunca do espectro da morte, aqui do monstro da morte. Parece que eros traz no seu rasto o seu indesejável irmão, thanatos.

Mas, julgamos, uma leitura freudianamente ortodoxa veria neste desejo hercúleo de esmagar a morte a vitória de eros, do desejo da vida sobre a atracção pela morte. Pelo amplexo sexual o poeta está a afugentar, a defenestrar a morte, mas uma leitura mais ambivalente está mais de acordo com a psique de Camilo. É na mesma rocha em que a hidra é esmagada que a cabeça de Vénus pousará para «ir inclinar-se, desmaiar de amor». Para ser verdadeiramente disjuntiva, o local da eliminação da morte não deveria ser o mesmo daquele da consumaçáo amorosa. Já antes, logo depois de se autocaracterizar nos termos mais eufóricos, acrescenta - «Tâo branco o peito! - para o expor à Morte...» - como intuindo de antemão que aqueles predicados não são suficientemente fortes para resistir ao poder da morte. Por ora, todavia, náo obstante a vitória da morte ser inelutável, que não se coloque entre si e a amada pois o poeta é suficientemente hercúleo para a vituperar e despedaçar («Mas que ora - a infame! - não se te anteponha. A hidra torpe! ... Que a estrangulo ... Esmago-a»).

Outra leitura, que diverge desta intromissão estranha da morte, é desenvolvida por Ester de Lemos que vê no impulso amoroso e no impulso guerreiro duas faces do mesmo sentimento: «da ideia de amor que, num belo primitivismo, leva o homem a expor-se, em todo o esplendor da sua juventude, aos olhos da mulher, passa-se insensivelmente a uma ideia de guerra e força, sem se perder de vista o primeiro impulso» ${ }^{42}$. Mas se ligarmos o presente soneto com «Vénus» (conjunto mais congruente para Óscar Lopes do que o díptico que prevaleceu), a imagem sadia do guerreiro que merece, por provada bravura, a aquiescência da amada desmorona-se. Com efeito, a «esvelta» e soberba Vénus é verdadeiramente estraçalhada por feras ondas (último terceto), o objecto do amor é aniquilado

nas últimas três quadras finais (a estrutura do poema é dividida ao meio, em partes simétricas) esse outro amor amodorrado, o poeta intenta mostrar a sua preferência pelo letargo. Como a mulher em «Interrogação» o protege da perturbação do crepúsculo, assim também é timoratamente que o sujeito se coloca sob as «saias» da mulher, para ousar "ver o mar», espaço de aventura, risco e prova. Teríamos assim in nuce alguns dos vectores da vivência do amor do poeta.

${ }^{42}$ Lemos, op. cit., p. 49. 
pelo desejo que suscita. Na interpretação de Anna Klobucka, esta subversão da alvinitente Anadiómede apresenta inequívocos traços de aniquilamento sádico, de que o próprio sujeito tem consciência («Em que desvios a razão se perde»): "A penetração do ventre pútrido, «azul e aglutinoso», da afogada pela onda (logo desdobrada em ondas: a cópula transforma-se em rapto múltiplo) produz intenso prazer tanto nos agentes do combate sexual quanto no sujeito falante do poema que, testemunhando a cena, se situa no papel de um voyeur ou, antes, de um senteur delirante de gozo ( o cheiro a carne que nos embebeda $))^{43}$. Portanto, nesta pulsão necrófila que se deleita com a decomposição do corpo que possui, amor e morte estáo misturados, náo separados.

Assim, se o primeiro soneto palpita de acção, o segundo é contemplativo. São agora os olhos a sinédoque do sujeito. Toda a aspiração do poeta está em olhar platonicamente a imagem da sílfide («Meus olhos querem desposar-te,/ Reflectir-te virgem a serena imagem»). A palavra virgem tanto pode referir-se à mulher como ao olhar do poeta e o verbo desposar traduz um anseio unitivo, uma unidade a realizar por meio dos olhos, contemplativamente ${ }^{44}$. Só que não é uma mulher concreta, é mais um esprit du lieu, a emanação feminina e etérea do imo, do fundo, da essência dos campos, das florestas. É a sua imagem serena que os seus olhos querem reflectir, não a sua presuntiva realidade. É um ser quase lendário, composto de alma de silfo e carne ou corpo de camélia.

Desta maneira, o fogo passional, os arranques de forcado dão lugar a um devaneio semi-onírico, que os "tons adormecidos» dos folhedos sugerem. Para nós, o elo de ligação dos dois sonetos reside nos «olhos ardidos» pela "chama do furor», em que se retoma o primeiro soneto no segundo. A vontade retesada pelo desejo físico e pelo desafio da morte não tem forças para suportar esta tensão por muito tempo, aspirando ao repouso, ao sossego bucólico da amenidade campestre entificado numa espécie de fada contemplada, espelhada pelos olhos à distância. Não já a dura rocha e o fragor do estrondear das ondas.

43 Anna Klobucka, "A (de)composição de Vénus: reflexôes sobre dois sonetos de Camilo Pessanha, in Colóquio/ Letras, no 104/ 105,1988, p. 39.

${ }^{44}$ É devido a este anelo de identificação, de se unir e de perder na união (como também se viu em "Se andava no jardim») que permite a Esther de Lemos arriscar que por vezes o poeta parece um místico - «... arriscaremos que Pessanha nos aparece às vezes como um místico, pela força com que deseja fundir sujeito e objecto: simplesmente o objecto nunca é Deus.», Lemos, op. cit., pp. 31, 32. 
A postura heróica, o que Christine Pâris-Montech designa por "élans héroïques», a desforra imaginária do abúlico, encontra expressão em outros poemas, nomeadamente em "Castelo de Óbidos», desencadeada em vista da conquista do beneplácito de uma figura feminina.

A vontade ou iniciativa individual funde-se numa vontade ou empresa colectiva, unificada em ordem a despertar o sorriso de uma Dama. $\mathrm{O}$ eu ascende ao plano do nós. $\mathrm{O}$ despedaçar da letargia pelo surto ou retorno do Portugal cavalheiresco de antanho (letargo mais caracterizado em «S. Gabriel», em que o navio-portugal se encontra imobilizado) é minado pela despositivaçáo das causas. As lutas a haver são prolepticamente declaradas "prolixas e vãs» e, sobretudo, a dama por quem os «lidadores» combatem, a Doce Infanta Real, é uma «magra figura de vitral», a imagem vítrea de uma imagem já distante, pois é colocada, no poema, num plano espacial superior, o varandim do «belveder».

A catadupa de interrogações retóricas sublinham a premência de um despertar, mas, simultaneamente, a sugestão da impossibilidade da concretização dessa meta. O ressuscitar de ideais congregadores orgânicos, em que a vontade individual coincide com uma vontade colectiva, em que o eu participa em algo mais vasto do que ele próprio, numa identidade comunitária, é minada à partida por um passadismo irrepetível. Mas o que interessa reter aqui, de acordo com a rubrica deste capítulo, é que a mulher é uma inacessível doce Infanta real, tornada ainda mais inatingível por aparecer transfixada num vitral.

A hipótese interpretativa de Rubim vê nesta Infanta enquanto «figura de vitral» (donde se tira que o seu sentido é o de uma imagem sempre figurada sem outro corpo, espectral por conseguinte, do que aquele que lhe confere a magra imagem gravada no vitral, isto é, a materialidade dos seus traços gravados) um indício seguro de que cada poema de Pessanha opera «o regresso de uma experiência de sentido que se decide ou permanece indecidida entre a materialidade das marcas e a evanescência dos espectros $»^{45}$. Elege-se assim Pessanha como poeta da escrita, mas retirando a esta última a marca de estabilidade e de solidez que tradicionalmente se lhe reconhece («scripta manent»), retirando ao estilete a energeia de representar um significado durável. Nesta linha, escolhe o soneto «Quando voltei encontrei os meus passos» como exemplo paradigmático de "uma alegoria da escrita»: os passos frescos sobre a húmida maré

${ }^{45}$ Rubim, Inscrição Espectral..., p. 3. 
são o símbolo da marca, do signo, do traço ou do vestígio do acto de escrita poética, estando destinados a desaparecer, apagados pelo refluxo da maré, mas também inevitavelmente substituídos pelo «novo rasto que começa» (no entanto, estes «passos» consistem noutra coisa mais do que vestígios deles mesmos: antes de mais são "meus», depois porque remetem para experiências vividas, passadas, pontuando a marcha da vida, de que o poeta, na sua sinédoque preferida, os olhos, lamenta o ter sido posta em movimento, sem rumo ou orientação, concluindo da inutilidade de todo o esforço, desejando ter-se imobilizado no "ponto» donde partiu). Estaria aqui insinuada a suposição de uma arqui-escrita que eternamente retorna produzindo novos traços sobre o apagamento de traços anteriores, semelhante ao distender e contrair das ondas do mar. Em reforço desta tese, da inanidade de qualquer inscrição, pode-se lembrar a lenda que conta que Pessanha molhava a pena na saliva, impregnada de ópio, donde resultaria que o papel em que escrevera, passados anos, ficava tão branco como se nada tivesse sido escrito. Só que esta lenda é uma faca de dois gumes: pode ser invocada para ilustrar o «mito» do poeta sem escrita, para quem o escrever os seus poemas era simplesmente acessório ou entediante, que elegia o espaço e a voz da memória como o «lugar» da poesia. É que sem o traço, a inscrição, o relevo da marca, por mais rarefeitos, arrepanhados, espectrais e portanto voláteis que sejam, toda a hermenêutica de Rubim cai pela base.

Seriando, então, as figuras de mulher indicadas, temos a mulher como revérbero da lua, a mulher anémica, a mulher marmórea, estátua, a mulher deusa Vénus, a sílfide, a mulher traçada no vitral. O que se retira desta recolha não é só a ausência de uma mulher concreta (em contrapartida, surgem frequentemente em António Nobre nomes próprios de mulheres), como, por consequência, a obliteração de um espaço em que um tu possa fazer soar a sua voz. O outro no amor permanece mudo. A relação é unívoca e não dialógica.

A dificuldade da entrega, seja numa paixão sensual, seja numa afinidade de almas, transparece na poesia «Interrogação», sem embargo de um certo dandismo, de um tom ligeiro e faceto que a envolve ${ }^{46}$. O sintagma que ritma todo o poema é um «não sei».

${ }^{4}$ Cf. João Camilo, "A Clepsidra de Camilo Pessanha», in Persona, 10, 1984, p. 25: "Um poema como «Interrogação", em que transparece um certo dandismo, dá-nos ainda uma visão do mundo leve e irónica, ligeira e superficial. $\mathrm{O}$ poeta não sabe se ama, mas sabe que tem prazer em estar com a mulher invocada no poema». 
Dúvida, indecisão, uma minúcia de matizes. Todo o poema é constituído por variaçóes do tema: "Não sei se isto é amor». A mulher parece ser sobretudo uma fonte de apaziguamento, de refrigério («Procuro o teu olhar,/ Se alguma dor me fere, em busca de um abrigo", "Mas sinto-me sorrir de ver esse sorriso/ Que me penetra bem, como este sol de Inverno», "Passo contigo a tarde e sempre sem receio/ Da luz crepuscular, que enerva, que provoca.»), mas não inspira nem a intenção de formar uma família («nunca pensei num lar/ Onde fosses feliz, e eu feliz contigo.»), ou paixão lacrimosa e romântica («Por ti nunca chorei nenhum ideal desfeito. E nunca te escrevi nenhuns versos românticos.») ou desejo sensual ( Nem depois de acordar te procurei no leito/ Como a esposa sensual do Cântico dos Cânticos.», "Eu náo demoro o olhar na curva do teu seio/ Nem me lembrei jamais de te beijar a boca.»). Hoje diríamos que exerceria sobre o poeta um efeito psicoterapêutico positivo.

Essa mulher parece ser saudável ("A tua cor sadia») e com os nervos sólidos, contrastando com a mulher anémica do poema seguinte "Crepuscular». Em ambos os poemas, é referido o crepúsculo e a susceptibilidade do poeta ao seu efeito perturbador. Porém, em «Interrogação», a mulher constitui uma barreira eficaz contra a melancolia do ocaso, enquanto que no poema seguinte "O vago sofrer do fim do dia» banha a mulher de máos pequenas com o seu langor.

É problemático inserir o soneto "Madalena» na classe dos poemas de amor, no sentido convencional, lírico, do termo. Mas todo o poema se organiza num paralelo entre uma Madalena, reduzida substantivamente a "cabelos de rastos» e adjectivamente a «nudez de seios castos», e o «meu coração» do eu poético. Avulta um desejo veemente de identificação com o destino trágico de uma "humilhada e ofendida», arrastada pela lama.

Um dos pontos problemáticos deste texto é a da relação entre a epígrafe evangélica e o soneto. No Evangelho de S. Lucas, as lágrimas derramadas e o enxugar os pés de Jesus são actos de arrependimento e penhor de redenção. Esta última palavra ocorre no poema, mas associada à morte, à rigidez anatómica do cadáver. Não se vislumbra qualquer traço de redenção efectiva em Madalena ou no sujeito.

$\mathrm{O}$ vaivém entre Madalena e o coração do poeta é dado por alternância. Os seis primeiros versos justapóem simplesmente os dois planos (a primeira quadra quebrando os versos a meio pela 
vírgula), operando o sétimo e oitavos versos, pela frase conjuntiva, o desiderato da identificação, do devir-outro. A tríade de adjectivos do oitavo verso exprime uma espécie de comunhão na decadência, na humilhação. A metáfora da "velha moeda fútil» e depois a implícita comparaçáo com o "abominável cómico ${ }^{47}$ sugerem que também o "coração» do poeta se prostituiu (este poema é uma amostra eloquente daquela tendência para a auto-deprecação que é anunciada logo no incipit em que o sujeito enunciador aspira a ser um verme). Por não ser firme e coerente, por tergiversar, representar papéis postiços, comandados pela necessidade de agradar à sociedade, como sugere o complemento causal do quinto verso. Daí o impulso para expiar uma vida oca e fingida na vertigem da degradação. A referência dupla ao sangue talvez marque esse sentido expiatório, mas uma expiação sem redenção. $\mathrm{O}$ penúltimo verso não tem sujeito gramatical, será propositadamente ambíguo, mas é mais verosimilmente atribuível, a acção de «Sangrar, poluirse, ir de rastos na lama», ao sujeito poético.

À imagem de Madalena, "lírio poluído», também o sujeito deseja poluir-se e, como a mulher perdida rojou os seus cabelos pelo chão, também quer ir de rastos na lama. A iteração é usada abundantemente neste soneto, o que reforça a intensidade emotiva, tensional. $\mathrm{O}$ primeiro verso é igual ao último fazendo coincidir, num círculo, o ponto de partida e o ponto de chegada. Outro verso se repete, variando o substantivo em posiçáo inicial, mas que são quase sinónimos - «Desespero, nudez de seios castos» e "Amargura, nudez de seios castos». O adjectivo "castos» aparentase a «lírio» e a «branca flor», sugerindo, talvez, uma pureza original que se maculou e se desnudou, sem culpa. A disposição paralelística dos dois versos póe como termo inicial um nome abstracto e como aposto, sem a mediação do determinativo, uma expressão concreta. Perante o desespero, a amargura, a saída é «o fastio da cama», a mole satisfação da inactividade, bem quentinho, bem calafetado, como no poema "Caranguejola» ${ }^{48}$ de Mário de Sá-Carneiro, à espera do desatar da morte.

${ }^{47}$ Verlaine estabelecera a incompatibilidade entre a poesia pura e a baixeza do riso: «Fuis du plus loin la Pointe assassine,/ L'esprit cruel et le Rire impur, / Qui font pleurer les yeux de l'Azur,/ Et tout cet ail de Basse cuisine!» (cit. por Arne Kjell Haugen, "Baudelaire: Le Rire et le Grotesque», in Littérature, no 72, 1988, p. 12). Neste contexto, é particularmente degradante, abominável, o coraçáo do poeta "puro" ter-se mascarado de palhaço, de "cómico".

${ }^{48}$ Mário de Sá-Carneiro, Poesias, Lisboa, Ediçōes Ática, 1991, pp. 157 159. 
O exílio como escape a um amor infeliz é o fulcro temático de «Canção da Partida».

O tom e o ritmo de cantilena popular, escolhidos pelo poeta, para vestir uma decepção, uma amargura profundas resultam certamente da sua poética náo confessional, da sua maneira disfarçada, enviesada de expressar o "sentimento».

Incrustado nesta toada, destacado pelo travessão, desenrola-se o verso décimo segundo em que se refere concretamente um «tu», o «teu noivado». O poeta, num triângulo amoroso, foi suplantado por um rival e excluído pela amada. A solução é a fuga: no verso "Quem vai embarcar, que vai degredado», o sujeito inclui-se implicitamente (também ele embarca porque foi degredado); o fechar o "coração» significa torná-lo insusceptível de cair noutro engano amoroso, sepultando-o nas águas salgadas e abissais do oceano. $\mathrm{O}$ "peso de ferro", que lembra as grilhetas dos condenados ao desterro, é o que mergulhará o coração irrevogavelmente nas águas purificadoras do mar.

No entanto, a quadra final, ao salvar o "lenço bordado» (prenda, penhor de esperanças, oferta tradicional da amada) do sepultamento faz duvidar da radicalidade dessa medida: o lenço supérstite é para embeber nas lágrimas da «água salgada» quando as do poeta secarem, como se o mar guardasse algo, por osmose, do coração nele lançado, prolongando-se desta maneira a dor e a saudade, que se queriam juguladas pela partida para o desterro, deixadas para aquém do infinito e intransponível fosso que seria o oceano.

Mas o amor é um dos modos da relaçáo intersubjectiva, não sendo amada a única alteridade a surgir na poesia deste autor. Temos apontado que nos poemas de temática mais ou menos amorosa o ser concreto desejado ou amado é subsumido por símbolos mais vastos como Vénus, a sílfide, Madalena, a mulher estátua e que lhe não é concedido pronunciar-se como, para muitos «idealistas», na relação eu - tu (distinguida por um Martin Buber da relação eu - isso, pela introdução da categoria do "entre» que salva a alteridade da redução a objecto e envasa a vida dialógica da reciprocidade interpessoal), deve ser constitutiva a restituiçáo de cada um à sua própria voz. Este deixar que o outro fale, pela instauração de um diálogo, surge em dois poemas, não obstante muito diferentes entre si. É esse ponto comum que nos permite emparelhá-los. 
Voz débil que passas,

Que humilima gemes

Não sei que desgraças...

Dir-se-ia que pedes.

Dir-se-ia que tremes,

Unida às paredes,

Se vens, às escuras,

Confiar-me ao ouvido

Não sei que amarguras...

Suspiras ou falas?

Porque é o gemido,

$O$ sopro que exalas?

Dir-se-ia que rezas.

Murmuras baixinho

Não sei que tristezas...

- Ser teu companheiro?-

Não sei o caminho.

Eu sou estrangeiro.

-Passados amores?-

Animas-te, dizes

Náo sei que terrores...

Fraquinha, deliras.

-Projectos felizes?-

Suspiras. Expiras.

\section{CAMINHO}

II

Encontraste-me um dia no caminho

Em procura de quê, nem eu o sei.

- Bom dia, companheiro, te saudei,

Que a jornada é maior indo sozinho.

É longe, é muito longe, há muito espinho! Paraste a repousar, eu descansei...

Na venda em que poisaste, onde poisei, Bebemos cada um do mesmo vinho.

É no monte escabroso, solitário,

Corta os pés como a rocha dum calvário,

E queima como a areia!... Foi no entanto

Que chorámos a dor de cada um ...

E o vinho em que choraste era comum:

Tivemos que beber do mesmo pranto.

\section{III}

Fez-nos bem, muito bem, esta demora:

Enrijou a coragem fatigada ...

Eis os nossos bordóes da caminhada,

Vai já rompendo o Sol: vamos embora.

Este vinho, mais virgem do que a aurora, Tão virgem não o temos na jornada... Enchamos as cabaças: pela estrada, Daqui inda este néctar avigora!...

Cada um por seu lado!... Eu vou sozinho, Eu quero arrostar só todo o caminho, Eu posso resistir à grande calma!...

Deixai-me chorar mais e beber mais, Perseguir doidamente os meus ideais, E ter fé e sonhar - encher a alma.

A proposta de camaradagem promanada da voz (sexto terceto de "Voz débil») não é acolhida pelo sujeito que alega desconhecer o caminho por ser estrangeiro. 
Pelo contrário, em «Caminho II», a saudação «Bom-dia, companheiro», parte do próprio sujeito, comportando um convite à companhia ("Que a jornada é maior indo sozinho»). Ora a jornada é a da vida e o caminho a calcorrear é muito longo, pedregoso, espinhoso, uma via dolorosa como expressivamente estabelece o primeiro terceto ( CCorta os pés como a rocha dum calvário»). O convite foi aceite e engendra-se uma comunidade vincada pela partilha dos mesmos gestos: pararam (certamente na berma do caminho abrigados pela sombra) para descansarem ambos, poisaram ambos na mesma venda, beberam do mesmo vinho. Gestos simples, mas belos na sua lhaneza.

Mais, a solidariedade aprofunda-se pois beberam do mesmo pranto, empatizaram com as dores um do outro. $\mathrm{O}$ monte escabroso indica uma etapa particularmente pungente do caminho da vida e até se pode supor que foi subindo pelas suas escalvadas encostas que subiram à venda onde no vinho que beberam derramaram as suas dores. A experiência da amizade foi retemperante, revigorante: «Fez-nos bem, muito bem, esta demora/ Enrijou a coragem fatigada». Urge partir, mas é necessário que o vinho da amizade, «mais virgem do que a aurora,/ Tâo virgem não o temos na jornada» (como quem diz que experiência solidárias como aquela dificilmente se repetirão) seja guardado e guardada também a esperança que encerra (como se depreende da comparação com a aurora).

Contudo, este homo viator (notem-se os apetrechos do viandante, até do peregrino - o bordão, a cabaça...), em vez de manter a irmandade, desagrega-a, em nome de uma de-cisão que escolhe um itinerário próprio, animado por uma solidão intrépida, uma vontade varonil: a repetição do pronome «Eu», as exclamativas do primeiro terceto, sublinham esse investimento volitivo de se demarcar de projectos comuns ou colectivos. Esta última expressão está de acordo com o imperativo plural que inicia o último terceto: o sujeito não diz «deixa-me», mas «deixai-me» ${ }^{49}$.

${ }^{49}$ A este pronunciamento de independência de espírito pode-se ligar o que afirma João Gaspar Simóes das aspiraçóes literárias de Pessanha artista enquanto jovem: «Camilo Pessanha, em 1888, com vinte anos, numa Coimbra onde mal afloravam ainda centelhas de uma poesia nova (o ultra-romantismo, o parnasianismo, o naturalismo estavam em crise), à margem de todos os grupos, isoladamente, concebia, congeminava, elaborava, uma arte poética que no fim de contas só ele viria a pôr em prática.», João Gaspar Simóes, Camilo Pessanha, Lisboa, Arcádia, 1967, p. 158. 
Aquilo que tinha sido uma experiência partilhada (o vinho bebido com lágrimas) é convertido, doravante, numa experiência pessoal: os ideais são «meus». Não se deve passar em claro a positividade do anelo do sujeito: «ter fé e sonhar - encher a alma». Não se deve de igual modo não reparar-se na estupenda expressão, sem encarecimento, em termos chãos, da experiência do companheirismo: a frescura da saudação, os gestos concretos, ricos na sua simplicidade, de partilhar a mesa e o vinho (até recentemente a hospitalidade aldeá passava pelo ritual de oferecer um copo de vinho), o verter recíproco das mágoas, a magnífica comparação do vinho puro da sintonia de almas à esperança da aurora, a luz que desperta depois das trevas. E é de tudo isto que o poeta prescinde, sacrifica, aparentemente, para escolher $m y$ $w a y^{50}$.

Se o companheiro de jornada é inequivocamente uma pessoa concreta, a voz que soa no poema do lado pode ser atribuível a qualquer um que passe.

A voz enquanto neutra e anónima recobre modulaçóes várias e veicula conteúdos psico-emocionais diferentes: desgraças, amarguras, tristezas (provavelmente histórias de...), e também a proposta de amizade, a confissáo de amores, de projectos felizes.

E não será descabido sugerir que essa voz é um símbolo, la voix humaine, recolhendo as preocupaçóes mais comuns dos homens de todos os tempos, sendo, contudo, o seu denominador comum a inanidade, a condenação a por fim expirar. "Dir-se-ia» que a "perdida voz» do choro da flauta de "Ao longe os barcos de flores» se amplifica, se deixa caracterizar, ganhando acentos humanos, mas sem deixar de ser «perdida».

O verbo final «Expiras» como que está anunciado no primeiro verso: a voz, além de débil, passa (é transitória, está destinada a passar, não a ficar - passamento, morte). A debilidade da voz escorre em quase todo o léxico desdobrado. A sua intenção comunicativa é vaga, indecisa, conjectural, até ao antepenúltimo terceto: «não sei...», "Dir-se-ia», «gemes», "pedes», "tremes», «Suspiras ou falas?», «rezas», «murmuras». Voz que soa não em dia claro, exposta, mas de esconso, «unida às paredes», «às escuras». Voz débil, de facto, lembrando o "gemebundo arrulhar dos

${ }^{50}$ É óbvio que se pode radicar essa recusa no carácter misantrópico do autor ( Novas amizades também me é impossível adquiri-las. Pois se eu não posso suportar ninguém!», carta a Alberto Osório de Castro in Pessanha, Contos, Crónicas, Cartas escolhidas..., p. 87). 
sonhos não sonhados», "o queixume brando» do expirar no vento das doces almas penando de «Poema Final». É a voz da dor, da caravana da dor do género humano, de «Branco e Vermelho».

Os travessões dos tercetos finais de «Voz débil» constituem, evidentemente, o eco de locuções articuladas pela voz. E é no primeiro terceto que vemos uma certa contraposiçáo aos companheiros de estrada do outro poema. Se foi o sujeito quem tomou a iniciativa na saudação ("Bom-dia, companheiro»), volveu-se agora no destinatário do convite ao companheirismo. Invertem-se os papéis. Mas o sujeito recusa, alegando ser estrangeiro e não saber o caminho. Curiosamente, aquele que se tornou companheiro de jornada até à encruzilhada da separação ("cada um por seu lado!...») também não sabia o que procurava, o que náo o impediu, ou talvez por isso mesmo, de se juntar ao sujeito. Como interpretar as razóes que dá para não corresponder ao pedido?

Poderia ser uma resposta anódina, do tipo "não sou de cá, pergunta a outro». Mas não carregará esse adjectivo, "estrangeiro», todo o peso do exílio, de quem o seu reino não é deste mundo, que por cá caiu, mas que não pertence aqui? E o não saber o caminho não significará uma desorientação radical, a derrelicção, o tal pessimismo derrotista e desistente?

E estas perguntas retóricas abrem a via para a (re)consideração do tonus emotivo dominante na poesia do autor: o tom desistente, abúlico, derrotista ${ }^{51}$, numa palavra, melancólico.

\section{4 - A melancolia e os seus objectos}

A melancolia (a bílis negra) e, na antiga caracteriologia, o homem melancólico, distinto do linfático ou do irascível ou do sanguíneo, eram postos sob o signo de Saturno, deus e planeta maléfico. Versão romana de Cronos, deus do tempo, é também na iconografia romana representado com uma foice, figurando assim como deus da morte. Se nos lembrarmos de que Saturno devorava os próprios filhos e que tinha amputado o pai Úrano para o desentronizar (o que coloca na origem da vinda à existência, do processo de individuação um acto de violência, uma separação traumática, fracturante), e que fora finalmente

${ }^{51}$ Considere-se que a evocação de "passados amores» por parte da voz é recepcionada pelo sujeito envolta em vagos «terrores» (a expressão «não sei que» atesta, simultaneamente, da debilidade da voz e da atenção do sujeito) e que é justamente quando a voz sopra futuros «projectos felizes» que ela expira. 
banido por Júpiter, escondendo-se no Lácio, não é sem razão que os antigos o ergueram como o foco mítico da tristeza, do negrume do coração.

Deste modo o deus que inspira a melancolia é o deus do tempo e da morte, da violência fundacional (e do ter-sido banido). A melancolia é, desenvolvendo a referência mitológica, como um "lago escuro" ${ }^{52}$, em que desaguam três rios, do tempo, da morte, da violência, como aqueles que regavam o tenebroso Hades (Aqueronte, Piriflegetonte e Cocito).

Arriscamos, ao pôr a melancolia em relação com aquelas "experiências», a engolfar o essencial de Pessanha neste capítulo, daquele que colocava como divisa do seu brasão «um ai, - que insiste noite e dia», repetindo o que se tem dito nesta dissertação.

$\mathrm{O}$ «risco» é aliás extensivo a largos blocos da produção poética ocidental, se nos ativermos a afirmaçóes como esta: «a grande poesia do Ocidente tem sido quase sempre a voz melancólica, desesperançada, aflita e solitária do sentimento de falta, de ausência, de precariedade, de finitudes ${ }^{53}$. Nesta linha, também Maria Zambrano afirma que «após a Épica, nasce a Lírica, que é essencialmente, Elegia, pranto...», onde "o problema do tempo aparece mais exacerbado do que nunca» ${ }^{54}$.

$\mathrm{Na}$ antiguidade, a escola peripatética (em Problemas) articulava genialidade e melancolia, inquirindo a razão por que tantos indivíduos que se destacaram nos mais diversos domínios, desde a política às artes, eram acometidos por esse humor negro de que não escapava o próprio Héracles.

Em tempos bem mais recentes, Eduardo Lourenço, falando de Pessoa, equaciona simbolismo e depressão (nome moderno para a melancolia): "No sentido mais cru do termo, Fernando Pessoa é o poeta da Depressão - histórica, psicológica, metafísica e psiquiátrica - que teve no Simbolismo de que é, em última análise com Mallarmé e Pessanha, a única expressão genial, a sua versão poética " ${ }^{5}$. Já Baudelaire punha ominosamente toda a poesia moderna sob um céu melancólico («Ciel mélancolique

52 «Ou para o lago escuro onde termina», $5^{\circ}$ verso do soneto «Imagens que passais pela retina».

${ }^{53}$ Vítor Manuel de Aguiar e Silva, «Comentário a «Morte ao Meio-Dia» de Ruy Belo", in Osvaldo Manuel Silvestre e Pedro Serra, Século de Ouro Antologia Crítica da Poesia Portuguesa do Século XX, p. 254.

${ }^{54}$ Maria Zambrano, "Apontamentos sobre o Tempo e a Poesia», in op. cit., p. 45 .

55 Cit. in Rubim, Inscrição Espectral..., p. 4. 
de la poésie moderne» ${ }^{56}$ ). À luz da frase de Eduardo Lourenço, também em Pessanha se poderiam escavar os diversos níveis da depressão/ melancolia.

Se as raízes psico-psiquiátricas e históricas da sua melancolia são facilmente reconhecíveis (abulia, «inibição psíquica endógena», absinto e ópio, o "país perdido», Portugal), já a expressão depressão metafísica lançada por Lourenço é mais enigmática. Talvez o termo se adequasse melhor a um Antero de Quental ${ }^{57}$, associando naturalmente a busca metafísica com o problema de Deus, porque na sua obra não palpita uma clara ânsia de Transcendência, como na do pensador açoriano, que instaure um drama existencial. A crença religiosa é vista como uma ingenuidade de infância, que o despontar do pensamento arruína, em "Soneto de Gelo» ${ }^{58}$. Curiosamente, o seu publicista João de Castro Osório fala da desorientação e da desolação de uma alma sem Deus.

Partindo da definição de Les Fleurs du Mal, cunhada pelo próprio Baudelaire (o grande precursor do Simbolismo) numa primeira versão, como um «misérable dictionnaire de mélancolie», Pierre Dufour propóe-se ler essa obra como um texto melancólico por hipótese, cruzando abordagens da psiquiatria moderna, da psicanálise, da história da cultura, e das obras poéticas melancólicas

${ }^{56}$ Cit. in Pierre Dufour, “Les Fleurs du Mal», Dictionnaire de Mélancolie”, in Littérature, No 72, 1988, p. 32.

57 O qual no mesmo ano da publicação das revolucionárias Odes Modernas escreveu a Alberto Sampaio que se ia "fazer padre», veleidade que testemunharia o pulsar de uma alma religiosa que no misticismo teísta teria encontrado realização pessoal, mas que, encontrando a porta fechada, se abisma em «desespero metafísico». Daí que o Cardeal Cerejeira tenha retirado do seu destino trágico uma ilustração de apologética. Antero teria podido fazer sua a famosa frase de um personagem de Os Demónios de Dostoiéwski: «Deus atormentou-me toda a minha vida», mas é duvidoso que pudesse ser perfilhada por Pessanha.

58 "As crenças de oiro» são encaradas como um embalo que adormece o bambino no seu berço e que um destino benigno manteria pela vida fora («Ingénuo sonhador - as crenças d'oiro/ Não as vás derruir...Deixa o destino/ Levar-te no teu berço de bambino,/ Porque podes perder esse tesoiro.»). Porém, o último terceto parece dirigir-se a alguém crente, provavelmente ele próprio, («O Deus, o mesmo Deus que te fez crente...»), responsabilizando a omnipotência de Deus pela perda da crença do sujeito ( $N$ Nem saibas que esse Deus omnipotente/ Foi quem arrebatou a minha crença.»), que quisera «um resto», «um lenho» de fé para não soçobrar nas trevas. O farol da fé, a luz que lança sobre o infinito apenas irradiam na condição de o sujeito não procurar, não pensar, manter uma ingenuidade pré-crítica. 
por elas mesmas enquanto discurso-espelho, isto é, discurso melancólico sobre a melancolia. Entre as diversas «démarches» que a argumentação do crítico acciona, interessa reter a afirmada função cognitiva do imaginário melancólico, alcançada pela via aberta de uma semântica cognitiva (teoria de extracção americana) cujo objectivo é o de reconstruir a unidade da dinâmica do discurso para além das clivagens entre semântica, sintaxe e pragmática. A dimensão figural, imaginária do sentido nasce de uma conceptualização, fortemente estruturada, de tipo arcaico, metafórico-analógico, que subsiste sob o sentido lógico-sintáctico. A manifestação dessa conceptualização analógica, parcialmente não proposicional, está nas metáforas mortas, lexicalizadas, estereotipadas, que promanam de um sistema cognitivo inconsciente que estrutura náo só a nossa linguagem, mas também os nossos conceitos, afectos, valores, o próprio vivido. O específico do «modelo cognitivo» próprio do imaginário melancólico está numa espécie de extremitas, de desmesura de que provêm o gosto pelo excessivo e a retórica da hipérbole...sendo os objectos melancólicos mais densos, implicados nesse modelo cognitivo, o espelho, a máscara, o labirinto, o mar, particularmente arcaicos, e por isso semanticamente mais pregnantes. É interessante verificar como este tipo de análise, estribada em princípios e orientaçóes da "semântica cognitiva», vem ao fim e ao cabo reunir-se, em muitos pontos, com uma leitura simbolista (nomeadamente, o papel central que aquela confere à analogia livre ou forçada, «contrainte»).

Se uma das fontes, remotas, da tristeza será uma violência fundamental, inerente ao acto de existir ${ }^{59}$, no caso de Pessanha, acresce a experiência de uma violentaçáo dos seus afectos mais caros, um desmoronar do refúgio que o poderia abrigar das tempestades da vida, a vivência do luto, da irreparável perda de um ser querido. É no extraordinário soneto «Quem poluiu, quem rasgou os meus lençóis de linho» que essa dor lacerante tem a expressão mais aguda.

Sendo o único poema de Clepsidra em que se refere explicitamente um familiar, «Ó minha pobre mãe!», é também o poema mais passível de uma leitura biografista, psicanalítica ou

${ }^{59}$ Certa psicanálise desenvolveu a ideia de que, marcando o nascimento uma separação, todo o ser humano carrega por toda a vida a fractura desse momento traumático, procurando, inconscientemente, o retorno à paz uterina (regressus ad uterum), à supressão da individualidade. 
de análise temática, desenvolvida por Jean-Paul Weber. António Quadros informa que, em Macau, em 1895 ou 1896, ao saber que a sua mãe estava a morrer, Pessanha jorrou a sua dor neste «desgarrador» soneto. Se foram essas as circunstâncias da produção do poema, está explicada a intensidade emotiva que o ensopa. Contudo, convém assinalar que o soneto conhece seis versóes ${ }^{60}$. De qualquer modo a interpretação de Quadros cola demasiado o significado do texto às figuras parentais, quando assevera que o $\mathrm{eu}$ devastado, profanado, das duas primeiras quadras «é a mãe» e o "quem», o agente da destruição, que no poema não é identificado, é o pai (que ele aliás respeitava, mas que naquele momento de desespero inculpa) ${ }^{61}$. A leitura psicanalítica é demasiado óbvia para nos cansarmos a sugeri-la. A «análise temática» deste poema poderia proceder, ora considerando a situação da infância (o estigma da ilegitimidade, "o poço de miséria e dor que foi sempre a casa do meu pai») do poeta, subindo para a sua expressão textual neste poema (é a démarche progressiva), ora partindo do texto, dos seus motivos, para remontar à infância (a démarche regressiva $)^{62}$.

Quem poluiu, quem rasgou os meus lençóis de linho,

Onde esperei morrer, - meus tão castos lençóis?

Do meu jardim exíguo os altos girassóis

Quem foi que os arrancou e lançou no caminho?

Quem quebrou (que furor cruel e simiesco!)

A mesa de eu cear, - tábua tosca de pinho?

E me espalhou a lenha? E me entornou o vinho?

- Da minha vinha o vinho acidulado e fresco ...

Ó minha pobre mãe! ... Não te ergas mais da cova.

Olha a noite, olha o vento. Em ruina a casa nova ...

Dos meus ossos o lume a extinguir-se breve.

Não venhas mais ao lar. Não vagabundes mais, Alma da minha mãe... Não andes mais à neve, De noite a mendigar às portas dos casais.

${ }^{60}$ Cf. Mário Garcia, «Sobre Camilo Pessanha», in Brotéria, p. 389.

${ }^{61}$ Quadros, Introdução..., pp. 34, 35.

${ }^{62}$ Cf. Carlos Reis, Técnicas de Análise Textual, Almedina, Coimbra, 1981, pp. $90,91$. 
A extensão e a profundidade dessa violentação são dadas, formalmente, por uma série de processos reiterativos ${ }^{63}$, e pela escolha de situaçóes e objectos constitutivos do espaço vital, íntimo do sujeito que a fúria dessa violentação vandalizou e destruiu. Justamente, a crueldade dessa destruiçáo ressalta da pureza dos rituais e objectos que violentou. $\mathrm{O}$ seu absurdo avulta por não se identificar a causa, a entidade responsável pela destruição ( $Q$ Quem destruiu...?»).

Os dois primeiros versos entrelaçam infância e morte. Os mesmos lençóis que o envolveram docemente na infância deveriam ser os que lhe serviriam de sudário na morte.

Pode-se detectar aqui o muito humano desejo de morrer na casa, ou na terra ou na pátria que nos viu nascer, desejo tornado impossível. Os castos lençóis de linho contêm as ideias de pureza e aconchego, visadas respectivamente pelo "poluiu» e pelo «rasgou». Do leito, o espaço da intimidade distende-se para o jardim, cujo simbolismo de paraíso é realçado pela luminosidade implícita dos altos girassóis, planta que é imagem do sol. O carácter exíguo do jardim reforça o seu valor íntimo, de recinto protector, e não é acidental que os girassóis sejam altos (altura, verticalidade, vontade, confiança, alegria de viver...).

Tínhamos notado já em «Caminho II» o encanto rústico do acto de sentar-se à mesa, de departir o mesmo vinho... Esses gestos que de tão simples, familiares e repetidos se tornam rituais que nos seguram à vida são aqui retomados e alargados. A nota rústica - a "tábua tosca de pinho», a lenha, o vinho, que, acidulado e fresco, pode indicar o vinho característico do Minho - expande as ideias de pureza, autenticidade e aconchego da primeira quadra. A brutalidade animalesca, desumana, da destruição é destacada pelos parênteses, ao jeito de comentário indignado: «(que furor cruel e simiesco)».

No segundo bloco do soneto, a dor ganha acentos ainda mais patéticos. Em situaçóes trágicas ou repulsivas, diz-se por vezes: ainda bem que fulano de tal já cá não está para ver isto... Um sentimento similar, mas mais complicado, anima estes tercetos. Pois à mãe que estaria morta, sepultada, é dada uma existência espectral, de «alma penada». Está e não está morta.

${ }^{63}$ No artigo já referido de Stephen Reckert (vide nota 117), a propósito de "Branco e Vermelho", o crítico chama a atenção para o facto de aspectos estilísticos desse poema fazerem lembrar a afirmação de Jakobson de que «à tous les niveaux de la langue l'essence, en poésie, de la technique réside en des retours réitérés». Esta observação é aplicável a outros poemas de Pessanha, como este. 
Paradoxalmente, ao apelo a não se erguer da cova segue-se o imperativo de "Olha a noite, olha o vento" e, subentende-se, olha «Em ruína a casa nova...» e a vida a extinguir-se no teu extremoso filho. Esta desolação devastadora imprime mais força ao triplo imperativo negativo que forma o último terceto. O cenário virtual da segunda parte do soneto é espectral e lúgubre. Cova, noite, o vento, propiciador dos espíritos, a «ruína», o vagabundear, a neve, o mendigar...

A origem dos fantasmas, dos espectros, das «almas do outro mundo", da sua aparição e da sua acção é atribuída, regularmente, a um nó existencial não resolvido, um crime hediondo a que não foi feita justiça, um segredo inconfessável que emerge fantasmaticamente (veja-se $O$ Espectro de Henry James), um amor que não foi realizado pela intervenção despótica de terceiros (lembre-se neste ponto $O$ Monte dos Vendavais), o luto não resolvido, etc.

Os espectros são normalmente reificações da reposição da justiça, ou de tormentos da consciência (as Erínias que profligam o criminoso que escapou à justiça humana...) ou da teimosia de não aceitar a ausência, por morte, de seres queridos.

O vagabundear, o mendigar da "alma da mãe» podem, assim, significar a errância de uma alma a que não se fez justiça, o prolongamento além-túmulo de um sofrimento inocente que continua a fazer ressoar a dor de um destino infeliz. As figuras da casa (nova, mas que decaiu inexplicavelmente em ruína), do lar, da mãe (cuja infelicidade ecoa, transfigurada em alma errante, tornada mais dilacerante por essa metamorfose) escalonam a muralha afectiva que protegeria o sujeito das forças da desagregação. Desfeitas essas defesas ...

Mas antes de incluir o tempo e a morte, palavras-chave do dicionário da melancolia, no imaginário melancólico de Pessanha, de modo a alargar o campo fenoménico da melancolia, faremos uma citação do estudo já mencionado: «a melancolia da tradição médico-filosófica apresenta-se como um "pacote» de relaçôes, atitudes e condutas, substâncias e objectos, frequentemente marcados por uma forte ambivalência (imobilidade ou errância, claustrofobia ou claustrofilia). Puros predicados qualitativos ou espaciais (negro, pesanteur, em baixo..) encontram-se associados a substâncias reputadas «saturnianas» (terra, pedra, lama e neve, chuva e tempestade, minerais e metais, chumbo, ferro, ouro...) e a objectos reputados melancólicos (espelho, escada, chaves, forno 
de alquimista, instrumentos de geómetra e de pedreiro, compasso, livro, tudo objectos presentes na "Melencolia» de Dürer; lugares e objectos funerários e todo o ritual da morte, ausentes da gravura de Dürer) $\gg^{64}$.

À luz deste vasto leque de sintomas, podemos detectar alguns desses traços do imaginário melancólico na poesia de Pessanha (a qual, dada a sua escassez, por um lado, náo oferece uma matéria extensa que multiplique os elementos repetitivos de conteúdo que formem a base ampla de um tema; por outro, tem a vantagem, na sua concisão vigorosa, de tornar um, dois exemplos, a base segura para extrapolaçóes temáticas):

- a tendência espiritual para a queda, que toma as formas do espojar-se na lama (soneto "Madalena») ou da fuga subterrânea ("Inscrição», "Na cadeia», "Porque o melhor, enfim,») e da fascinação apavorada pelo abismo («o abismo não sondeis»);

- a chuva como lacrimae rerum e simultaneamente como reflexo e projecção das lágrimas, da melancolia íntima do sujeito em «Água Morrente», que une este tópico, explicitamente respigado de Verlaine, com o tema anterior: o sujeito desdobra-se, apelando para os seus olhos se fixarem e depois se identificarem, numa gradação descendente, com «a água morrente», gerúndio que associa água e morte: ao imperativo «vede» a água «cair, sempre cair», verbo que "quase» coincide com morrer - "Cair, quase morrer...», sucedem os fusionantes «afogai-vos», "Caí e derramai-vos» ${ }^{65}$; o poder de dissolução da chuva, aliada da morte, é invocado num poema de circunstância, "Em um retrato»: a terra fresca que "há-de inumar» o sujeito é potenciada na sua função obliteradora pela chuva abundante - «E depois de já muito ter chovido,/ Quando a erva alastrar com o olvido»;

- a fascinação com a mineralização da vida, com os restos da vida consumada, acontecida, o seu retorno à sua fase larvar

${ }^{64}$ Pierre Dufour, "Les Fleurs Du Mal», Dictionnaire de Mélancolie”, in Littérature, No 72, 1988, p. 37.

${ }^{65} \mathrm{O}$ cotejo com o «original» de Verlaine é realizado por Jacinto do Prado Coelho em "De Verlaine a Camilo Pessanha e a Fernando Pessoa», in Ao Contrário de Penélope, Lisboa, Bertrand, 1976, pp. 209 - 214. Ao mesmo nível de excelência na musicalidade, o poema de Pessanha, o que é influenciado, "é mais complexo, mais perturbante que o de Verlaine» (ibidem, p. 211). Na nossa opinião, não será mais complexo, mas é de certeza mais perturbante, porquanto a tristeza indefinida do "coeur» do sujeito do poema de Verlaine é envolvida, afagada pelo «bruit doux de la pluie», pelo "chant de la pluie», enquanto que no de Pessanha a chuva não canta, cai, é água morrente no seio da qual os «olhos» do sujeito são compelidos a «afogar-se». 
e mineral (o verme da "Inscrição», «Seixinhos da mais alva porcelana,/ Conchinhas tenuemente cor-de-rosa(...) róseas unhinhas que a maré partira.../ dentinhos que o vaivém desengastara.../ Conchas, pedrinhas, pedacinhos de ossos...», em «Singra o navio.»). Expandindo a nota de Óscar Lopes acerca da menção dos "vestígios mineralizados», relíquias desvitalizadas de afogamentos, de naufrágios, Perrone-Moisés vê no mundo poético de Pessanha o plasma do fracasso visto, menos na sua eclosão, no fragor do seu despedaçar, do que no «depois» dos seus remanescentes, concisamente apontados: «Assim que se entra no universo poético de Pessanha, percebemos logo que chegamos demasiado tarde. Já tudo aconteceu, e tudo acabou mal. A sua poesia é um constatar de sinistro. Este universo de depois do desastre constitui-se de restos e indícios, tanto mais pungentes quanto o poeta no-los apresenta de maneira sucinta e contida. Traços evanescentes de um caminho percorrido sobre a areia, sulco de um barco que acabou de passar»" ${ }^{66}$.

O momento do derrame melancólico não é o do deflagrar da tragédia, chocante, violento, mas o momento posterior, o das suas consequências e da sua perdurabilidade em ruínas e vestígios. Alguns poemas iniciam-se, marcando explicitamente esse momento reflexivo posterior (por exemplo, «Depois da luta e depois da conquista", "Eis quanto resta do idílio acabado", "Quando voltei encontrei os meus passos», «Depois das bodas de oiro», "Parei a cogitar», "Porque o melhor, enfim»). A fixação nos vestígios do que foi, na decomposição do orgânico no inorgânico tem como contrapólo, remontando o fluxo da vida, o deter-se na fase embrionária, latente da vida: as cores represadas no limbo e os abortos parados, embebidos no líquido morto de vasos de laboratório no "Poema final». A vida, a existência é um breve e doloroso intervalo entre extremidades onde mora o não ser;

- a efemeridade das flores, a secreçáo de morte que libertam com o desmanchar da sua beleza (as "Anémonas, hidrângeas,/ Silindras, - flores tão nossas amigas!», decoração conivente com o idílio, desaparecidas e substituídas pelas urtigas, planta agreste, repulsiva, em "Eis quanto resta do idílio acabado»; a «Dália a desfolhar-se - o seu mole sorriso...", o seu deperecimento suave, levemente irónico, levemente resignado, em «Foi um dia de inúteis agonias.»; «Putrescina: - Flor de lilás./ Cadaverina: Branca flor do espinheiro!», as flores despidas das suas galas pela

${ }^{66}$ Cit. in Rubim, Inscrição Espectral..., p. 34. 
acção purificadora do sal e do sol, reduzidas à podridão, em «Roteiro da Vida»);

- a errância, o errar sem saber ou não querer saber para onde se vai, o "náo sei por onde vou, sei que não vou por aí», o estar bem onde não se está ("Que eu desde a partida,/ Não sei aonde vou.», «Nem sei de onde venho» ${ }^{67}$ ).

Outras manifestações de melancolia, não contempladas na citação: a perturbação do crepúsculo, que pode reunir-se ao tema da queda (o ocaso do sol, a imobilidade pensativa dessa hora, a agonia da luz e a iminência da chegada da noite), as paisagens de inverno; a atracção pelas ruínas.

Também a melancolia segregada pelos espectáculos teatrais. De facto, a frase The show must go on pressupóe o vazio, o abatimento do show realizado, terminado, de que importa reemergir. "Vai declamando um cómico defunto./ Uma plateia ri, perdidamente,/ Do bom jarreta... E há um odor no ambiente/ a cripta e a pó, - do anacrónico assunto.» - a gravação pelo fonógrafo, eco de um evento desvanecido, reforça a inanidade do riso convulsivo da multidáo e a vanidade da performance do cómico; daí o salto associativo para o bolor das coisas irremediavelmente passadas, sepultadas pelo tempo, no seu odor sui generis; aflora-se aqui o velho tema barroco do teatro, vazio postiço da vida? Pour cause, a forma de auto-deprecação escolhida em "Madalena» é a do "abominável cómico», daquele a quem lhe afivelaram uma máscara que o torna outro que não ele próprio, obrigado pela vulnerabilidade do seu carácter fraco a mascarar-se ad populum.

$\mathrm{O}$ derruir das ilusóes, o amargor do desengano. Com efeito, no temperamento melancólico coexistem as sacudidelas reactivas à estagnação (a fase maníaca, eufórica do maníaco-depressivo, em que se podem radicar os referidos "élans héroïques», inchados pela megalomania ${ }^{68}$ ) e o rememorar ora mais resignado, ora mais

${ }^{67}$ Em carta a Carlos Amaro, salientada num post sriptum, o conhecido desabafo: «P. S. - Sabe o que eu agora desejaria? Não chegar ao meu sítio nunca... Ir assim, a bordo de um navio, sem destino.» $\mathrm{O}$ último parágrafo desta carta merece também ser citado: «Veja como o destino varia. Nos últimos dias de Lisboa, o terror que verdadeiramente me oprimia era este mar morto da viagem, entre dois abismos tâo distantes um do outro, e no fundo de cada um a minha alma perpetuamente agoniza.» (Pessanha, Contos, Crónicas, Cartas escolhidas..., p. 95).

68 «Timbre: rompante, a megalomania...», em "Tatuagens complicadas 
dolorido da sua inutilidade: este balancear do espírito é detectável em muitos versos da Clepsidra: "O barro que em quimera modelaste/ Quebrou-se-te nas mãos. Viça uma flor.../ Póes-lhe o dedo, ei-la murcha sobre a haste...» - a implícita comparação ao gesto criador de Adão, a escolha do símbolo da flor, como concreçáo do vigor e da beleza, marcam mais impressivamente a crueldade da ilusão que não se prolonga, que não concede mais tempo ao engano, desfeita pelo mero contacto físico, como que amaldiçoado, do sujeito.

Essa celeridade do desfazer da ilusão é ainda mais sinteticamente expressa no verso «Castelos doidos! Tão cedo caístes!...», evocando a imagem dos castelos as metáforas lexicalizadas dos «castelos de areia» ou dos «castelos no ar»; um oriental diria «tigres de papel», segundo os clichés sedimentados na sua cultura.

Um soneto que seleccionamos como revelador desta dialéctica engano-desengano e que serve na perfeiçáo como elo de transição para a temática da morte, o pôr da morte como corolário do desengano inevitável, é «Depois da luta e depois da conquista».

Depois da luta e depois da conquista

Fiquei só! Fora um acto antipático!

Deserta a Ilha, e no lençol aquático

Tudo verde, verde, - a perder de vista.

Porque vos fostes, minhas caravelas,

Carregadas de todo o meu tesoiro?

-Longas teias de luar de lhama de oiro,

Legendas a diamantes das estrelas!

Quem vos desfez, formas inconsistentes,

Por cujo amor escalei a muralha,

- Leão armado, uma espada nos dentes?

do meu peito». De notar o adjectivo, o particípio presente «rompante», que quadrando com "megalomania» acerta no cariz compulsivo desses safanóes da inércia depressiva, dessa descarga de energias represadas pelo marasmo precedente da fase depressiva (estas consideraçóes pressupóem a equivalência conceitual entre «melancolia» e "psicose maníaco-depressiva», doença de foro psiquiátrico, caracterizada pelo ritmo bipolar de depressão e expansão... A depressão, contudo, é subdividida pela vulgata da psiquiatria contemporânea em diversas sub-espécies: depressão melancólica e depressão nevrótica, endógena e exógena, unipolar e bipolar, etc. Arriscámos a hipótese da «depressão bipolar», sem de todo pretender ler a poesia de Pessanha como uma sintomática de um caso clínico, devido a esses sobressaltos de acção, às arremetidas de uma vontade prima facie heróica que latejam em alguns dos seus poemas). 
Felizes vós, ó mortos da batalha!

Sonhais, de costas, nos olhos abertos

Reflectindo as estrelas, boquiabertos...

Uma observação prévia: para quem duvidasse do denso simbolismo da poesia de Pessanha, a leitura deste soneto acabaria com todas as dúvidas: o congraçar de «Ilha», do mar cor de esmeralda, da caravela, do oiro e pedrarias preciosas, da muralha de fortaleza ou castelo, dos mortos fitando, ausentes, o céu estrelado; esta intersecção de imagens e situaçóes formando um todo congruente, enlaçadas por um estado de alma ou sentimento subjacente...

$\mathrm{O}$ primeiro verso configura um momento reflexivo - como se tem visto a posição espiritual preferida de Pessanha, que foca mais os resultados da acção, o «depois» dos acontecimentos, que o seu in fieri: na baliza deste verso a luta não foi em vão, foi coroada pela conquista.

Porém, o verso seguinte coarcta o que se poderia esperar de um acto de conquista: «fora um acto antipático»" ${ }^{69}$, epíteto antónimo de admirável, por exemplo, e o troféu, o espólio, não foi senão a solidão. Solidão emoldurada por um quadro condizente: a Ilha está deserta, rodeada por um interminável lençol aquático verde.

A cor lembra as impenetráveis florestas tropicais, sublinhando o papel aprisionador do mar. Desde Robinson Crusoé, pelo menos, que é bem poderosa e dramática a imagem da ilha deserta com um único habitante, entregue a si mesmo e, além disso, sem tesouro, o que a ilha de Stevenson guardava no seu seio. Ilha e caravelas ligam bem, pois era de barco que se alcançavam as ilhas e as caravelas quinhentistas demandavam as «ilhas desconhecidas». Mas este poema sugere a frustre situação do aventureiro que, atingida a ilha, descoberto ou conquistado o tesouro, vê-o levado por outrem, doravante encarcerado pelo fosso intransponível do oceano, numa ilha deserta A solidão cria um ambiente propício à reflexão, ao balanço implacável dos nossos actos e dos acontecimentos.

Assim, a transmutação metafórica, pela sua elevação e sublimidade, dos ideais ou projectos pessoais em caravelas, carregadas de «todo o meu tesoiro», depois em «formas

${ }^{69}$ Por indução, Óscar Lopes afirma que, para o autor, "Qualquer conquista é um acto antipático» (Lopes, Entre Fialho e Nemésio, p. 120). 
inconsistentes», mas que concitaram o vigor indómito do poeta, tornado leão, de espada nos dentes, tão bravo que vence muralhas, torna mais fragoroso o fracasso. O próprio tesoiro: «- Longas teias de luar de lhama de oiro,/ Legendas a diamantes das estrelas!» ${ }^{70}$ participa do esplendor épico e maravilhoso que o imaginário nacional confere à caravela (os navegadores tinham como dossel o bordado doirado das estrelas). A imagem de bravura guerreira conduz o poema para o «depois» da batalha, em que os que pereceram são invocados como «felizes».

Mas, como sucede em outros poemas ${ }^{71}$, a morte não significa a aniquilação total, pois os mortos sonham, os seus olhos não estão cerrados, e uma nota de espanto admirativo se desprende de «boquiabertos»: os mortos como que são «apanhados» num «entre», no limiar indeciso da transiçáo da vida para a morte, num doce esvaimento (com a consequente eufemização da morte) de que nascem o sono e o sonho.

E são os olhos desvitalizados, desaparecido o ardor do desejo, que espelham as estrelas, fixando a sua imagem (ao contrário do que ocorre em «Imagens que passais pela retina», na retina viva de olhos acordados). É este estado intermédio, dormente, sedativo, semi-consciente em que o ser ou a vida deslizam para o náo ser e que permite um breve contacto unitivo entre sujeito e objecto, que parece ser o estado tolerável para o poeta ${ }^{72}$.

Camilo Pessanha confessava numa carta, já citada, a Alberto Osório de Castro, que «eu também ando por esses mares fora sempre a escolher o melhor lugar da minha sepultura ${ }^{73}$. Tínhamos visto como no seu principal texto crítico, em que praticamente elege esse seu amigo como seu duplo literário, o poeta afirmava a omnipresença da morte, advertindo o «choque» eventual do leitor mais sensível, ao aduzir que nada há nisso de escandaloso, lançando uma pergunta retórica que em si mesma não admite discordância: «De que havia pois, de lamentar-se, ou contra o

${ }^{70}$ Cruzem-se estes versos com o "doce clarão irreal» «da luz, do Bem», a «ardentia,/ avivada das quilhas», lavrando "um montão de estrelas», o efeito da «feeria do luar» na «brancura» das velas do díptico «San Gabriel». A imagem guerreira do leão a escalar muralhas lembra a saída para o combate dos «antigos e puríssimos lidadores» e as formas inconsistentes o sorriso de vitral da infanta de «Castelos De Óbidos».

${ }^{71}$ Por exemplo, em "Porque o melhor, enfim».

${ }^{72}$ Cf. os versos do terceto final com os de Milosz, evocando o seu cemitério de Lofoten: "Les morts, les morts, ils sont au fond plus vifs que moi» (cit. in Eduardo Lourenço, Heterodoxia I, Lisboa, Gradiva, 2005, p. 59).

${ }^{73}$ Pessanha, Contos, Crónicas, Cartas escolhidas..., p. 86. 
que havia de insurgir-se, se a morte é, em relação à vida, não só o termo fatal, mas a consequência lógica?» ${ }^{74}$. Era como se alguém discordasse de que nascemos para morrer.

Não obstante, se a morte é tão natural como a vida, um facto biológico entre outros, seguir-se-ia uma atitude de aceitação, não de insurgimento, de «encolher de ombros», não de lamento, o que não sucede manifestamente na poesia de Pessanha. Epicuro punha de lado a problemática da morte e o seu drama com este sofisma, que Sartre retomará com outros desenvolvimentos: «enquanto existes, não existe a morte; quando a morte sobrevier, então não existes tu». Portanto, o temor, o drama da morte são declarados infundados: a morte permanece sempre exterior e impensável, só poderíamos falar dela quando a experimentássemos, quando morrêssemos. Mas, mortos, já não o podemos fazer.

Nada disto acontece em Pessanha: este imagina-se morto, enterrado e, ilogicamente, ainda a ver, ainda a sentir de algum modo. A morte permanece um problema inquietante. Com certeza, conjecturo, não acharia satisfatória a ideia de Marx de que a morte é simplesmente o tributo que o indivíduo paga à espécie, apesar da índole daquela pergunta retórica.

Raros são os poemas do autor em que a morte não espreite. Mas já não é a morte em geral, como acontece no artigo crítico, mas «a morte própria» ou a morte do outro, daquele que ama, como a sua mãe, em "Quem poluiu».

O tempo, por outro lado, não é imagem da eternidade como para Platão, mas a marcha da morte («le temps mangea la vie», num verso de Baudelaire). Não querendo coligir todas as referências directas ou indirectas à morte esparsas na maior parte dos seus poemas, sob pena de redundância, trilharemos o caminho mais curto de definir a atitude ou as atitudes fundamentais do autor perante a morte.

Assim, a atitude prevalecente é a do desejo da morte enquanto cessação do desejo e do sofrimento, enquanto "quietação» e «olvido»; por conseguinte, a sua eufemização.

As primeiras quadras do soneto, "Desce por fim sobre o meu coração», ilustram-na cabalmente: "Desce por fim sobre o meu coração/ O olvido. Irrevocável. Absoluto./ Envolve-o grave como véu de luto./ Podes, corpo, ir dormir no teu caixão. A fronte já sem rugas, distendidas, / As feiçóes, na imortal serenidade,/ Dorme enfim sem desejo e sem saudade/ Das coisas não logradas ou perdidas.».

${ }^{74}$ Ibidem, p. 59. 
A repetição do advérbio ("por fim», «enfim») parece a exalação de um suspiro de alívio em dois tempos. $\mathrm{O}$ «olvido» da vida que a morte acarreta é reforçado pelos adjectivos sequentes, destacados pelos pontos, constituindo uma tríade gradativa. $\mathrm{O}$ paradoxo de qualificar a «serenidade» da morte como imortal significa que essa serenidade não será mais perturbada pela agitação do desejo e da saudade, afinal deceptivas (respectivamente, "das coisas não logradas» e das coisas "perdidas).

A «quietação do olvido» que enobrecia a esmaecida inscrição tumular em "Eis o que resta do idílio acabado» confere uma gravidade, uma placidez de estátua tumular jacente. A sorte dos mortos é destarte invejável, e por isso envoltos por um certo «halo» de nobreza: como vimos, os mortos da batalha são declarados felizes, e os seus olhos ainda abertos unem-se por breve reflexo às estrelas e, similarmente, os homens, «escravos condenados» à dor enquanto vivem, no desmaiar da morte tombam, ou o sujeito deseja que tombem, "De costas e serenos», beijados pela luz «nas amplas frontes calmas» («Branco e Vermelho»). Por isso, apela à mãe que não se erga mais da cova, aos sonhos errantes e lacerados que adormeçam, à voz débil que definitivamente expire.

Este aspirar à morte como um adormecimento ou um desmaio, encarando-a como libertação «doce», retirando-lhe todo o terror, é uma variação, o andamento predominante, mas não único.

Em «Imagens que passais», a metáfora do "lago escuro» ressumbra um «vago medo angustioso» e, em «Esvelta surge», a morte não é desejada, mas combatida, e vencida, sendo a sua metáfora a monstruosa Hidra.

Por outro lado, o desejo de morrer toma também o modo, não de um doce esvaimento, mas de um despedaçar cru e brutal. A modalidade do "suicídio masculino», a inversão destrutiva da vontade heróica. A morte violenta tem no poema mais cruamente auto-deprecatório de Pessanha como causa eficiente o trem dum comboio arquejando ( $«-S e$ o esmagasse o trem/ Dum comboio arquejando!...») e em "Enfim, levantou ferro», é desejado o naufrágio do navio (metáfora da vida do sujeito) nos termos mais violentos - «Nalguma rocha ignota/ Se vai despedaçar, com violento fragor...».

A Hidra pode ser considerada, além de símbolo da morte, também, concomitantemente, símbolo do tempo ${ }^{75}$. A sua ligação

75 Apud Christine Pâris-Montech, op. cit., p. 112, “"a negatividade insaciável» do Tempo devorador de instantes, que irresistivelmente nos arrasta 
é desdobrada no único poema, «Caminho I», em que o sujeito fala explicitamente de presente e futuro, numa meditação centrada na dor:

Tenho sonhos cruéis: n'alma doente

Sinto um vago receio prematuro.

Vou a medo na aresta do futuro,

Embebido em saudades do presente...

Saudades desta dor que em vão procuro

Do peito afugentar bem rudemente,

Devendo, ao desmaiar sobre o poente,

Cobrir-me o coração dum véu escuro!...

Porque a dor, esta falta d'harmonia, Toda a luz desgrenhada que alumia As almas doidamente, o céu d'agora,

Sem ela o coração é quase nada:

Um sol onde expirasse a madrugada,

Porque é só madrugada quando chora.

É o tempo da alma, o tempo vivido ou subjectivo («n’alma doente/ Sinto»). A coloração afectiva no encarar do futuro é a da angústia, pois é um indefinido, um «vago» receio, infundado e prematuro, próprio de uma alma doente, cujos sonhos que podem bem ser projectivos, «futuríveis», são «cruéis». O futuro não é uma clareira de possíveis, mas uma lacerante «aresta» ${ }^{76}$.

Contudo, o presente não oferece qualquer apoio $^{77}$ : o sujeito descola-se, distancia-se da hora presente pela saudade: «embebido em saudades do presente». A vivência do presente é desde logo desgarrada - o presente, o momento, a circunstância, logo se convertem em saudade, em objecto de recordação, tornando-se passado.

para o nosso destino final...”.

${ }^{76} \mathrm{Cf}$. «E as asas lacerais nas arestas dos telhados», verso do "Poema Final».

$77 \mathrm{O}$ tempo como prisão, sem janelas para o passado, presente ou futuro, impossibilidade pura, triângulo de dor, é a vivência desdobrada em «Depois das bodas de oiro": "Temo de regressar... /E mata-me a saudade.../Mas de me recordar/ não sei que dor me invade.» - a tendência imperiosa da saudade, mas que se volve num pungir sem qualquer delícia; "Nem quero prosseguir,/ trilhar novos caminhos,/ Meus pés, dorir,/ Já roxos de espinhos. Nem ficar ... e morrer.../ Perder-te, imagem vaga.../ Cessar... Não mais te ver.../ Como uma luz se apaga...» - nem trilhar, nem ficar, nem regressar; a única saída é cessar, não ver, morrer. 
$\mathrm{Na}$ melancolia, com efeito, em virtude da sua retracção ou inércia características (ao contrário, como se diz, do homem prático, activo, empreendedor, que vive inteiro no hic et nunc, aderindo à realidade que o cerca), o tempo parece não passar e, como evasão, é habitual o refugir para a saudade ou recordação. Esse voltar-se irreprimível para trás, este sugar do presente pelo passado é marcado pelo particípio «embebido», o qual sugere que o sujeito não tem espaço de manobra. Mas as saudades que, no sentido mais comum do termo, seriam de bens perdidos, têm como genitivo "desta dor» (é a dor que alumia o "céu d'agora»).

Estamos perante um paradoxo: como se pode ter saudades de uma dor e ao mesmo tempo querer suprimi-la? A explicação está em que a dor é inescapável. O sujeito sabe-se destinado ao véu escuro do poente (na gíria filosófica, ser-para-a-morte), derradeiro acto daquela dor. É perceptível que «esta» dor, particular, passa, nos tercetos, a «a dor». Nestes, o sujeito defende uma concepção global que se poderá chamar de "dolorismo». O coração não pulsaria sem a dor, como um sol não existiria sem a madrugada que o traz à existência... A madrugada, o vir à existência, tem como condição sine qua non, o chorar, a dor.

Mas a meditaçáo sobre o tempo na poesia de Pessanha escolhe sobretudo a via do símbolo, a água, na sua valência negativa ${ }^{78}$, pondo de lado a enunciaçáo genérica de passado, presente, futuro como categorias abstractas, misturando-os na "corrente da consciência», no que Bergson entendeu por durée, fluxo da vida interior, sucessão subjectiva e qualitativa de estados psíquicos, mas sem a continuidade criadora que o filósofo francês lhe reconhecia. Estes vectores meditativos estão bem ilustrados no célebre díptico "Paisagens de Inverno»" ${ }^{79}$, que serão lidos conjuntamente, onde soa também (e por isso, não é desajustado o termo «meditação») a voz reflexiva, aquele «poder de dissociação» que Pessanha elogiava na poesia de Osório de Castro.

Essa voz reflexiva é patente na primeira quadra: o sujeito divide-se, interpelando, advertindo «olhos» e "coração». A parte do sujeito que adverte será a da "razão prática», a prudência

78 "A água é epifania da infelicidade do tempo, ela é clepsidra definitiva», Gilbert Durand, apud Christine Pâris-Montech, op. cit., p. 116.

${ }^{79}$ Publicado como díptico em 1897, é como tal apresentado na terceira edição de Clepsidra de João de Castro Osório, mas na primeira edição, na de 1920, surgem separados (cf. "Introdução» de Barbara Saggiari, in Camilo Pessanha, Clepsidra e outros poemas, Edição crítica organizada por Barbara Spaggiari, Lello Editores, p. 32). 
que tenta dissuadir os impulsos passionais do "coração» que se reflectem nos «olhos». Ao fogo destrutivo e calcinante do desejo ("pecado», "olhos febris»), o sujeito opóe como remédio o retorno de «longas noites de paz» como se alguma experiência passada pudesse ser revivida. A noite longa apazigua, quer dizer, congela o desejo. Então, da memória, camareira do tempo vivido, emerge uma paisagem nocturna de Inverno (neve, cinza, o casebre transido - note-se a concordância entre «o brasido» e os «olhos incendiados», queimados). O elemento humano do "casebre transido" é enunciado como termo comparativo do apelo aos olhos para cismar (frio - velhice - morte).

Contudo, esse imperativo é iludido no terceto seguinte para ser reafirmado no último. "Extintas primaveras, evocaias»: rebenta, como se diz noutro poema, "o campo florido das saudades», agitando de febre os "olhos». A radiosa felicidade do significado humano da Primavera é dada pela invocação do ritual antigo de engrinaldar "os chapéus de maias». É encantador o modo como se exprime a alegre expectativa, a alegria assegurada, de contemplar a floração do pomar das macieiras ("Já vai florir») e a euforia contagiante (do eu e dos outros - «Hemos de enfeitar») de participar da ridente estação, através da não utilização do pretérito perfeito.

Poder-se-ia perguntar porque é que o sujeito não se fixa à duração do reviver desses momentos felizes. Diz-se de Proust que na evocação do tempo perdido fulgem cintilações de eternidade, pois o passado como que se reactualiza, torna a viver. Não assim na poesia de Pessanha.

Neste caso, a evocação de tão encantadoras primaveras provoca não um brilho de contentamento nos olhos, mas febre, a que convém pôr cobro («Sossegai, esfriai»). Nos dois versos finais, fica-se na dúvida se na pessoa verbal se inclui apenas o sujeito e os seus olhos ou se o sujeito se incorpora num grupo de «doces vozes senis», entoando tenuemente as "derradeiras ladainhas», o que envia para rituais fúnebres. $O$ soneto então imbrica, nomeadamente pelos tempos verbais, passado, presente e futuro, mesclando as idades (juventude e velhice) com as estaçóes do ano. O presente é marcado pelo ardor («onde ides a correr», «meus olhos incendidos»), avaliado negativamente ("desatinado», "pecado», «sol» abrasivo, destruidor). Donde o apelo à sua cessaçáo através da evocação de quadros invernais, e correspondente apatia subjectiva. $\mathrm{O}$ ressurgir desse ardor relapso (o passado morde o 
presente com a renascença do desejo) motiva nova intervenção da voz reflexiva que aponta para o futuro da senilidade, «doce», preferível pois ao repetir do vão desejo.

No soneto seguinte, opera-se novamente a divisão ou desdobramento do sujeito em partes: «olhar cansado», «vão cuidado", "coração vazio", interrogados de forma similar ao coração e aos olhos do primeiro soneto. Também correm agora, sendo objecto de reparo ou censura, o "vão cuidado», "o coração vazio", as «melancolias». Adiciona-se o Outono, o arcaico símbolo do rio heraclitiano e traços de uma imagem feminina balanceada nas águas, a delineação muito vaga de um objecto de desejo. Acentuase a transitoriedade do tempo vivido e do tempo "objectivo» (as estaçôes), donde procede que a extrema fluidez do tempo implica a irrealidade (ilusão, engano, mentira) do mundo, do não-eu.

Como uma vaga que sobe e desce, assim o ritmo partido do primeiro verso. A repetição do advérbio «já» conota a vertigem da passagem e o tornar do frio poderá marcar o triunfo do inverno (no fim, é o inverno, a velhice, a morte que vencem). Os elementos do primeiro verso são retomados e expandidos nos três versos seguintes: "Outono de seu riso magoado» - deliciosa animizaçáo, as cores, as tardes do Outono ainda riem (lembrem-se as colheitas), mas de um riso reticente, magoado, pois o Inverno está à porta. Este verso, poder-se-ia lê-lo às avessas: «seu riso magoado de Outono", mas o problema está em atribuir o possessivo: aos olhos, ao coração, à mulher flutuante, às melancolias?

$\mathrm{O}$ «frio» do primeiro verso é ampliado num «álgido inverno» em que as coisas atingem a maior das transparências, através da combinação de um sol gelado (não encandeador) e das águas límpidas de um rio. Neste difuso cenário, aparentemente, o sujeito debruça-se sobre as águas claras, trespassadas pela luminosidade solar, do rio que foge. Dissemos aparentemente, porquanto essas águas «fugindo sob o meu olhar cansado» podem significar a torrente do tempo interior que cavalga o «coração vazio». Esta ambiguidade tem expressão sintáctica no terceiro verso, em que não é certo o sujeito do verbo «levais» («águas» ou «meu vão cuidado»?). Como foi notado por Esther de Lemos, neste soneto não se configura um lugar, um espaço de contornos definidos: o rio iluminado pelo sol de inverno "parece não ter margem» ${ }^{80}$, esbatendo-se como rio concreto para se transformar em algo que corre, leva de imagens, sonhos e visóes.

${ }^{80}$ Esther de Lemos, op. cit., p. 46. 
Não há geometria na poesia de Pessanha, os seus versos não são exactos como os alexandrinos de Cesário. O vórtice do tempo devora a estabilidade do espaço. Bergson defendia que as demarcaçóes de passado, presente e futuro eram o resultado da intromissão do espaço (partes justapostas) no tempo, cuja essência é a durée, fluxo, sucessão pura, cognoscível pela intuição, não pelo intelecto. Mas a durée avança, acumula, enriquece e progride. A memória é simultaneamente veículo e guardiã da duração. Nada se perde, tudo é recuperável.

Em Pessanha, ocorre tendencialmente o contrário: o tempo é um esvaziamento, um "sorvedouro» ${ }^{81}$, um caudal de fragmentos que não encaixam. Daí o imperativo que inicia o primeiro dos tercetos e que se poderia estender a objectos, afectos, reminiscências, a tudo o que o intelecto e a vontade visam. Nietzsche dizia que o ser foi inventado por aqueles que sofriam com as transformaçóes. Ora, o poeta sofre agudamente com o movimento incessante, irreversível e aniquilador, o tempus fugit, mas não encontrou ou inventou qualquer ser que o contivesse ou rodeasse.

Aliás, o sujeito de enunciação dirige-se a partes de um corpo flutuante e não a um tu. Sugere-se, como em pinturas cubistas, partes separadas que o meio aquático ondulante, apesar de límpido, desfoca ( $\mathrm{E}$ refractadas, longamente ondeando,/ as suas mãos»). Pois se não é claro que o rio seja exterior ao sujeito, também não é nítida a realidade da imagem ofélica. Não se tratará de uma alucinação das "melancolias», uma miragem do "coração vazio", um reflexo especular do sujeito? Noutros termos, se a imagem e, principalmente, os seus «olhos abertos e cismando» não serão uma duplicação narcísica do sujeito.

Temos assim a típica indefinição ou confusão entre interior e exterior, sujeito e objecto, passado e presente. $\mathrm{O}$ poder de dissociação em Pessanha esquece-se, ao contrário de Alberto Osório de Castro, de «discriminar a participação da própria alma» ${ }^{82}$, quer dizer, de dividir analiticamente os campos do sujeito e do objecto. Para isso, o «mundo» de Pessanha teria que ser estável ou relativamente estável.

81 "Violoncelo».

${ }^{82}$ Pessanha, Contos, Crónicas, Cartas escolhidas..., p. 59. 


\section{5 - «A DISTÂNCIA SEM FIM QUE NOS SEPARA»: A UNIDADE COGNOSCITIVA IMPOSSÍVEL}

Esther de Lemos distinguia na poesia do autor dois tipos de poemas, os de intercepção e os de coincidência com a realidade, salvaguardando que nenhum poema é uma amostra pura desse tipo. Trata-se de uma oscilação do sujeito, consoante o grau de intervenção dessa voz reflexiva que, como se viu, tenta dissuadir ou cercear à nascença qualquer actividade desiderativa ou cognoscitiva do sujeito.

Uma conclusão de uma escola budista diz que o que há a compreender é que nada há para compreender. Um conhecido verso de Alberto Caeiro sentencia a mesma ideia: «o único sentido das coisas é não terem sentido nenhum». Ora, Pessanha nunca se elevou a este tipo de ataraxia. As feiçóes distendidas, imperturbáveis, nunca são o resultado de uma paz das profundidades, mas o efeito passageiro de superfície da cessação da vida, antes que comece o implacável processo de deterioração.

Pessanha quer compreender e conhecer («A vista reconstrói»), gostaria de dizer que sabe donde veio e para onde vai, quisera ter um lenho para não soçobrar na "treva imensa», mas a decepção destes anseios, do «seu represado desejo de vida»" ${ }^{83}$, deixa um ressaibo, uma amargura indisfarçáveis. $\mathrm{O}$ pessimismo do autor fere o nível mais básico do conhecimento: a mera percepção sensorial, os dados dos sentidos, as imagens recebidas.

Se quiséssemos transladar para linguagem filosófica, diríamos que Pessanha é um empirista (não parece haver margem para um conhecimento, intelectual ou espiritual, de essências ou verdades inatas ou do suprasensível), que não reconhece um tecido conexivo (lógico) entre as sensaçóes, qualquer regularidade que sustente uma lei de sucessão dos fenómenos do sentido externo e do sentido interno. Este radical fenomenismo e atomização (objectiva e subjectiva) forma um todo com a atitude moral, como se tem dito, derrotista, amargurada e desistente em relação à relação intersubjectiva e ao sentido da vida em geral.

Uma maneira de apresentar esse todo é colocar lado a lado o último dos «Sonetos» e a última das «Poesias». Cepticismo perceptivo e categorial e pessimismo vital. Mas antes de proceder a essa leitura conjunta, importa dizer algo sobre alguns dos poemas que se inclinam mais para aquele tipo de poema, coincidente com

${ }^{83}$ Esther de Lemos, op. cit., p. 187. 
a realidade, segundo o esquema de Esther de Lemos. Uma leitura desprevenida, aliás, veria nesta expressão a infirmação da tese do cepticismo cognitivo do poeta. Contudo, o aspirar à identificação, a uma unidade com o não eu, que vibra em alguns dos poemas mais característicos, é irrealizável ou simplesmente momentânea. São os estímulos musicais que parecem abolir essa «distância sem fim» em momentos de certa fusão: em «Fonógrafo», a sucessão dos registos sonoros, de diferentes músicas, engendra atmosferas (onde elementos visuais se agregam a elementos olfactivos) como se o sujeito fosse o receptáculo amplificador, o complemento do fonógrafo. A barcarola suscita um quadro aquático e lunar, em que o sonho do poeta é referido como "extática corola», como se, na audição da barcarola, o sujeito saísse de si; depois vibra uma música de clarim e cornetas que condensam os sons e os aromas da antemanhã. Findo o som destes instrumentos, solta-se uma manhã primaveril, propagando-se o eflúvio das violetas como se estivesse encerrado na "alma das cornetas».

Em «Viola chinesa», o fundo calar da música não suscita essas atmosferas de delícia sensorial, mas remexe uma "cicatriz melindrosa» do seu coração, uma dor vaga, pois o poeta interroga o quê, a natureza dessa cicatriz (a interrogação é levantada obviamente pela designada voz reflexiva que indaga, quer entender...).

Em «Ao longe os barcos de flores», a música da orquestra da orgia distrai, encobre a gravidade da "hora» (tempo, vida, «o abismo») - «Festôes de som dissimulando a hora», mas é com um som de flauta, que não faz parte da orquestra, que o sujeito, também, deduz-se, um solitário, empatiza. Novamente intervém a interrogação, marcando mais uma vez a vontade indagadora do sujeito que quer compreender - «Quem há-de remi-la?/ Quem sabe (...)». O título da poesia é interessante para o ponto de vista que se tem desenvolvido: é ao longe que a orgia cintila, a distância e a noite abafam o reboar da orquestra; porém, o som fino da flauta, o seu trilar modulado, o seu choro derramado atravessam inexplicavelmente a noite e a distância. Se o barulho da orgia "dissimulava», postiçamente, refalsamente, a "hora», por contraste, o gemer da flauta exprime-a. Entre a flauta e sujeito, há uma afinidade de exilados. Não terá assim, como já aventámos, a misteriosa flauta um papel adunatório do sujeito com a hora, sendo o seu trilar a música de um exílio universal, da dor da cisão dos seres, que com essa dor exprimem a saudade do Uno (a flauta, 
em certas religióes, "symbolise l'âme séparée de sa source divine et qui aspire à y retourner $\left.{ }^{84}\right)$ ?

Não o choro da flauta, mas o do violoncelo desencadeia uma catadupa, uma torrente impetuosíssima de associaçóes de imagens. A análise deste formidável poema foi feita por Esther de Lemos que o fez tão bem que passou a ser obrigatória a remissáo para o seu trabalho. Relativamente aos precedentes «choros» musicais, em que, em princípio, o foco está no instrumento, o som soando e o sujeito vibrando como um sismógrafo, neste poema o sujeito como que se sobrepóe, guia e ritma a música do violoncelo «Chorai arcadas/ Do violoncelo!».

Se a outra fase da melancolia ou depressão é o frémito maníaco, não é gratuito supor que o poeta o terá escrito em transe maníaco que se caracteriza, em contrapartida à fase da inércia e inibição melancólicas, pela aceleração do pensamento, pela efervescência de recordaçōes, de construçôes mentais e imaginárias, de associações imponderáveis de tal modo que pode desembocar no salto da psicose em que a imagem que o sujeito faz da realidade substitui a realidade. As arcadas metamorfoseiam-se em pontes, a música num caudal de coro, num rio alastrando ruínas de barcos («Lemos e mastros...»), de edifícios («E os alabastros/ Dos balaústres!»), desaguando, apaziguando-se em vastidóes lacustres, em região polar («Blocos de gelo»). As duas últimas estrofes, anteriores à repetição do imperativo, a que a junção de "despedaçadas» acentua a transfiguração alucinada, funcionam como anticlímax, o esgotar da descarga em águas paradas e sombrias onde bóiam destroços e «urnas quebradas». A grande sombra parada da morte, portanto.

A sensibilidade musical do poeta permite-lhe abandonar-se a esses momentos unitivos que não são, porém, necessariamente balsâmicos ou seráo aliviadores no sentido em que a uma dor mútua, uma dor que encontra o seu eco, se derrama (com excepção de «Fonógrafo»). É que a música é ambivalente: enquanto repetiçáo e harmonia aspira ao senhorio do tempo, eufemizando o seu fluir; enquanto variação, inversamente, mantém o drama, o desacordo dialéctico ${ }^{85}$. Esta ambiguidade essencial da música

${ }^{84}$ Jean Chevalier et Alain Gheerbrant, Dictionnaire des Symboles, p. 710, cit. in Christine Pâris-Montech, op. cit., p. 227.

${ }^{85}$ Ideia desenvolvida por Gilbert Durand, amplamente citado por Christine Pâris-Montech, op. cit., pp. 205, 209, 217, 218. Segundo Durand, «la suavité musicale si chère aux romantiques est de doublet euphémisant de la durée existentielle», aspirando a «maîtriser le devenir par la répétition des instants 
permite lançar as mais sedutoras hipóteses sobre a motivação da poesis de Pessanha, por exemplo, a de que a fluidez musical dos seus poemas terá promanado da ambição de suavizar, diferir a angústia adstrita à aguda consciência da fugacidade do tempo, da efemeridade de tudo...

$\mathrm{Na}$ visão, o mais intelectual dos sentidos, a tentativa de unidade marcha sobre um caminho mais árduo.

Em «Singra o navio. Sob a água clara» [Vénus II], a visão é mais que receptiva, perscrutadora, indagadora. Ou melhor, podem-se demarcar uma fase receptiva e uma outra, que lhe sucede, a fase indagadora.

Singra o navio. Sob a água clara

Vê-se o fundo do mar, de areia fina...

- Impecável figura peregrina,

$A$ distância sem fim que nos separa!

Seixinhos da mais alva porcelana,

Conchinhas tenuemente cor-de-rosa,

Na fria transparência luminosa

Repousam, fundos, sob a água plana.

E a vista sonda, reconstrui, compara.

Tantos naufrágios, perdiçôes, destroços!

-Ó fúlgida visão, linda mentira!

Róseas unhinhas que a maré partira...

Dentinhos que o vaivém desengastara...

Conchas, pedrinhas, pedacinhos de ossos...

O navio (eu, percurso vital pessoal, vida em geral) singra, mas move-se lentamente, mansamente, permitindo a constituição de uma espécie de visão de aquário. O sujeito do segundo verso é indeterminado ("vê-se»), o olhar objectivo. Contudo, o travessão introduz a voz pessoal: essa «impecável figura peregrina» não está ao alcance dos olhos. Certamente, dado o contexto, o referente dessa figura será Vénus. Porém, não, dados os adjectivos, a Vénus desfeita, estraçalhada do soneto anterior, nem provavelmente a

temporels», como se depreende de «l'obsession de l'unité sous la diversité que révèle le refrain, le rondo, la variation, la passacaille et la chacone»; porém, «si la musique est d'abord harmonie, elle n'en est pas moins contraste dramatique, valorisation égale des antithèses dans le temps», de igual modo "mariage harmonieux» e "dialogue», "procès dramatique». 
"esvelta» Andiómena, dada a perturbação sensual que esta provoca. Será antes um símbolo, a Beleza que se persegue e não se alcança. Sem sair do tópico venustino, a Vénus coelestis dos neo-platónicos. Ou será antes a Vénus decomposta, os seus restos mineralizados, purificados e polidos pelo fundo tranquilo do oceano?

O que permite a dúvida sobre este referente, que a continuação do texto legitima, é, não o epíteto «impecável», que se ajusta perfeitamente ao papel purificador das águas salgadas, mas "peregrina», não parada ou sepulta, e o próprio nome "figura», o contrário de uma dispersão de partes.

Toda a segunda quadra desenvolve uma descrição objectiva, em que algo dos predicados convencionais da beleza da mulher petrarquista subsiste («alva», «tenuemente cor-de-rosa»...). Mas o sujeito não se detém nesta visão de aquário: «E a vista sonda, reconstrui, compara", chamando a si operaçóes judicativas, realizando um trabalho analítico sobre os dados dos sentidos.

Segue-se a conclusão: essa louçania, essa beleza de coral são o resultado de toda a sorte de destruiçóes. É então uma beleza fictiva, enganadora: o seu fulgor, a sua beleza são epifenómenos, encobrem uma "mentira», desmascarada pelo olhar diligente do sujeito. A descrição final é assim já influenciada pela certeza da ilusão. $\mathrm{O}$ cinzel que poliu, que conferiu a delicadeza de porcelana aos restos mortais de Vénus foi o vaivém das marés, a erosão marítima, o resultado do acaso destruidor.

"Ó fúlgida visão, linda mentira» poderia ser o mote do último dos sonetos, mas onde as imagens perdem toda a luminosidade, despojadas de toda a aparente beleza. A visão fúlgida de "Vénus II» é estática, fruto de uma contemplação. No soneto final, essa possibilidade de contemplação demorada, de fixação das imagens é descartada.

As imagens não são tidas na conta dos objectos, o que significa que Pessanha não se coloca numa posição realista de fundo que pressupóe a existência da res e a imagem como sua re-presentação no ou pelo sujeito. Por outro lado, as imagens passam na retina dos olhos, não são interiorizadas, retidas pela actividade cognoscente (entendimento, intelecto, etc). O sujeito parece ter como único órgão cognoscitivo o sentido externo da visão e, nos olhos, apenas a sua superfície especular, a sua retina ${ }^{86}$.

${ }^{86}$ Em «Branco e Vermelho» menciona-se o «fundo da pupila», um «dentro» dos olhos, mas aqui a pupila não tem fundo, é uma fina película, exterioridade pura. 
Trata-se, assim, de um sensismo puro, que dá só lugar ao visível, mas que não confere qualquer espessura ou valor à sensação. Além de as imagens não terem qualquer substância (não são emanaçôes das coisas, a sua cópia, nem elaboraçôes do sujeito), ou justamente por causa disso, são puramente instantâneas, passam, deslizando na retina, para "nunca mais» (verbos de movimento - «passais», «não vos fixais», «ides», «levais»). São imagens sem retorno possível, que passam e se nulificam. A conjunção disjuntiva ou não oferece nenhuma alternativa, mas a repetição da mesma ideia da primeira estrofe. Adensa-se a rede de símbolos para significar o papel nadificante do tempo. O tempo náo revela nada (como se diz comummente que com o tempo vem a verdade ao de cima, nem esculpe o que quer que seja), escoa para o não ser. A água cristalina que simboliza a sucessão deslizante das imagens escurece, sombreada pelos «juncais», esmorece o seu movimento, rodeando-se de um sinistro silêncio ("curso silente de juncais»), espraiando-se na soidáo lacustre, o plutónico «lago escuro». Por isso, dado o seu termo inelutável, o apelo às imagens, que assim se personificam, formula um desejo de se esvair, de desaguar também no lago escuro.

O apelo é dramático, como se se dirigisse a uma amada rebarbativa: «Sem vós o que são os meus olhos abertos?». Mas mais vale cerrar as pálpebras, como é explicitamente enunciado em «Porque o melhor enfim» e em «Poema final», porquanto as imagens são "formas inconsistentes», radicalmente evanescentes pois passam irrecuperáveis. Perdidas as imagens e o seu rasto, a ânsia de encontrar um ponto fixo volta-se para o mais rudimentar dos gestos, o de agarrar, de prender com as máos. Contudo, o derradeiro recurso («fica sequer») é igualmente deceptivo. Nem a sombra das mãos permanece, o seu mexer-se é meramente acidental, movimento de títere sem titereiro, estranhamento de um sujeito relativamente ao seu corpo, a que não pode chamar corpo próprio.

A vanidade do movimento de imagens e gestos ocorridos no campo do sujeito, condu-lo, dado o império do náo sentido ${ }^{87}$, em

${ }^{87}$ Numa carta, já referida anteriormente, a Alberto Osório de Castro, à fórmula de petição de nativos para cativar esmolas, desejando muitos anos de vida e muitos filhos, opóe Pessanha um esfriante, céptico "para quê»: «(...) a desejarem muitos anos de vida (para quê?) e muitos filhos, todos prolíficos até à $5^{\text {a }}$ geração (para quê?)", Pessanha, Contos, Crónicas, Cartas escolhidas ..., p. 85 . 
«Poema Final», ao extravasar da sua esfera subjectiva, apelando ao não existir, ao não-ser, de entidades potenciais ou virtuais que, num passo, atravessariam o limiar, o outro lado da barreira onde se agita o ser e a vida: cores, embrióes e sonhos, configurando uma escala ascendente.

O que interessará reter é que esses seres virtuais abrigam em potência uma negatividade a que o ser, o pôr-se em acto, expandiria, como um vírus retido por um cordão sanitário se propaga pelas suas brechas. O limbo das cores é já um limbo infecto: «vermelhos de hemoptise», "cromáticas vesânias». A luz, soltando as cores subterrâneas, seria cúmplice da sua propagação virulenta. Os embrióes pendem as frontes numa postura meditabunda, a cujo cismar chega "o correr da água da clepsidra», vão gotejar, que suscita um concordante sorriso vago, resignado e ateu. Os olhos desprovidos de imagens eram "pagãos»; analogamente, o sorriso dos abortos, imóveis e encerrados em bocais de museu, escutando o longínquo escoar do relógio de água, é resignado e ateu. Esta aproximação mostra que paganismo e ateísmo, no pensamento de Pessanha, não parecem ser animados de espírito empolgante, como em outros autores, mas simplesmente expressão de descrença descoroçoante, desilusáo abatida, expressão de nihilismo, numa palavra. É paradoxal atribuir uma atitude pensativa, auscultadora a embrióes e persuadi-los a suspender a sua cogitação, a não sondar o abismo (Pessanha evita a aporia de se dirigir a seres inexistentes, conferindo-lhes actividade e desejo). Se o sorriso dos fetos é, no seu estádio, resignado e ateu, se lograssem crescer, ultrapassar a barreira do tubo e do museu, restava-lhes alargar o sorriso na gargalhada, a resignação em vã revolta, mergulhar mais fundamente no precipício.

Fernando Pessoa, ortónimo, escreveu que «não quero mais que um som de água/ Ao pé de um adormecer» ${ }^{88}$. Este adormecer significa a suspensão da actividade consciente e interpretativa, o ouvir o correr da água como um embalar soporífero, em que crença ou descrença não se póem. Pelo contrário, em Pessanha, o correr de água é medido pela clepsidra, o que significa um prazo, uma consciência das horas que passam, do limite e do finito.

Quanta interrogação e busca estão por detrás de resignação e ateísmo, de um vago sorriso, por isso mais invulnerável ao que quer que seja de contra-prova. Cores, abortos e sonhos estão já prenhes

${ }^{88}$ Fernando Pessoa, Poesias Inéditas (1919-1930), Lisboa, Ed. Ática, 1990, p. 154. 
de vida, quer dizer, de inquietação e de dor, prefiguração demasiado flagrante da existência ao ar livre. A virtualidade dos sonhos é expressa pelo paradoxo "sonhos não sonhados», mas que manifestam a vida de aéreas «almas penadas» - emitem sons, um "gemebundo arrulhar», vagueiam durante «toda a noite», dispóem de asas que laceram «na aresta dos telhados», transposiçóes de dramas domésticos, de dores que não de extinguem de dia. O seu expirar é um queixume brando que o vento recebe no seu seio e propaga. Por mais brando que seja o expirar, não evita a laceração, a dor. $\mathrm{O}$ adormecer dos sonhos é como reaprisionar o génio que se soltou da lâmpada, o devolver do envelope ao destinatário, o pôr os traumas em estado de coma.

Portanto, nem ao sonho é reconhecida a capacidade de evasão: Proust dizia que mais valia sonhar a vida do que vivê-la, mas neste terrível «Poema Final» é cerceada essa ilusão.

\section{6 - UM ESTRANHO ABSOLUTO}

Afinal, um abismo se cava entre o sujeito, foco de conhecimento e de desejo, e seu objecto. Qualquer intersecção que ocorra está condenada a durar muito pouco como as pegadas na areia à beira mar. Se o sentir e o pensar acarretam por natureza, incoercivelmente, a dor e o fracasso, a solução estará na sua suspensão, num movimento regressivo para um aquém, num fugir para baixo ou na sua superação, num subir.

Esta última via, a duma ascensão conducente a um estado extático e místico, em que o sujeito se esquece de si, é sugerida em «Branco e Vermelho»: "Não sinto já, não penso,/ Pairo na luz, suspenso...».

O que catapulta o sujeito para esse plano é o aguilhão da «dor, forte e imprevista». Este último adjectivo é na primeira oitava repetido por três vezes, o que remeterá para uma vivência de todo súbita e improvável, um choque inesperado. $\mathrm{O}$ que essa dor atinge é a visão, o mais analítico dos sentidos. Este perder os sentidos está de certo modo implícito no adjectivo «branca», empregada adverbialmente: "A dor ...ferindo-me ... de branca...».

Também por três vezes - a tríplice iteração é profusamente utilizada ao longo do poema, o que aponta para toda uma simbologia de plenitude associada a esse número - se mostra o efeito deslumbrante da dor na vista, pelo emprego de três verbos quase sinónimos: «endoidou», "perder», «fugir». A segunda oitava explicita esse «deslumbramento», esse "doce esvaimento». A comparação dos quatro primeiros versos apenas apresenta o termo metafórico, 
«um deserto» por três vezes imenso, «branco» e «resplandecente» e náo o termo real, o que significará uma deslocação para uma outra ordem, a do sobre-real. $\mathrm{O}$ «fez-se em redor de mim» indicará que a vontade do sujeito não teve parte na indução dessa experiência. Exprime-se um êxtase, um arroubo que eleva a totalidade do sujeito, sem distinção entre corpo e alma, sentidos e intelecto («Todo o meu ser suspenso»). Todo o seu ser paira, acedendo a um estado de inebriamento espiritual - "Que delícia sem fim!», a um reino esplendoroso, de superabundante luz.

E é sub specie aeternitatis, como através dessa amplidão luminosa, reflectido "no fundo da pupila», que o sujeito vê um desfilar de "pobres corpos nus», a "caravana» "da enorme dor humana». É uma visão de sobrevoo, de quem está muito acima, muito distante. Porém, se desse plano distante, os corpos se reduzem a pontos quase indistinguíveis numa mancha «sem fim», na quinta oitava, descrevem-se «um a um» esses corpos, descendo a câmara do olhar ao seu nível. É como o voltar à caverna, um inclinar-se compassivo, o retorno de quem teria passado o limiar da humana infelicidade: o estalar do chicote que golpeia os escravos é sentido na carne do sujeito («E as pálpebras me tremem/ Quando o açoite vibra.»).

Mais que uma caravana de escravos, penando pelo deserto africano, é toda a história da humanidade na sua marcha dolorosa e absurda que é desse modo coalhada. Dizia cinicamente Anatole France que a única noção de infinito que concebia era a da estupidez humana. $\mathrm{O}$ que parece ser infinito para Pessanha é a dor humana («sem fim»). Enorme, insigne, porém, afinal, inútil. $\mathrm{O}$ carácter «insigne» da dor abre para uma possibilidade de redençáo que logo o verso seguinte dilui: «a inútil dor humana».

Uma via dolorosa, em que a multidão é impelida pelo chicote, obrigada a avançar pelo medo, "curvada a fronte», "até ao chão», não vendo senão o chão, sem esperança alguma: os que caem são obrigados pelo golpear do azorrague a reerguerem-se, evocando as quedas de Cristo. A sua única saída é o estatelar inanimado no chão, quando o golpear do algoz e o terror que inspira deixam de ser sentidos, de fazer efeito. Os que perecem restam insepultos na areia. Não há tempo, nem motivo para os inumar.

Então, no desmaio final, estendidos sobre a areia árida, «ali fiquem serenos,/ De costas e serenos.../Beije-os a luz, serenos,/ Nas amplas frontes calmas». Em vida, eram «magros, mesquinhos e vis»; com a morte uma amplidão serena, uma inesperada nobreza 
se desprende das suas frontes. Em vida, estavam curvados até ao chão, não levantavam a fronte e o olhar; com a morte, finalmente, deitados de costas, contemplam "céus claros e amenos». Verifica-se um paralelo entre o "doce esvaimento» do sujeito e o desmaiar, o esvair ("Até que enfim desmaiem» (...) «Ei-los que enfim se esvaem») dos escravos tombados.

A morte é libertação («Até que enfim(...)»!). Todavia, a originalidade deste poema, no todo da obra de Pessanha, é que o modo da «libertação" não é o do desaparecimento, mera abolição de vida e dor, mas um salto, o cumprimento mirífico de uma promessa. A penúltima oitava retoma e repete a primeira e a segunda, cruzando-as, condensando-as. Há duas invocaçóes neste poema, tendo de permeio a retoma que a penúltima oitava constitui: "Ó céus claros e amenos», "Ó Morte, vem depressa». Contudo, estas apóstrofes não se contradizem, pois os céus claros e amenos, os doces jardins amenos, constituem a "promessa» que o acordar da morte possibilita. A morte é figurada como uma irmá da caridade - «Vem-me enxugar o suor», dando passagem à realização do sonho. Os doces, repousantes, amenos jardins, florescem em vermelho, estuantes de vigor e de vida.

Será fútil perguntarmo-nos se estes "doces jardins amenos», este "tudo vermelho em flor» terão um significado transcendente ou transcendental, na acepçáo kantiana e husserliana dos termos, ou, por outras palavras, se se situam fora ou dentro do sujeito? A pergunta não terá grande sentido se inscrevermos este poema no filão da linguagem e da experiência dos místicos, em que as distinções interior/ exterior, dentro/fora, sentir/ pensar são ditas insuficientes ou desajustadas.

Porém, sejam quais forem as causas e circunstâncias desta "experiência», é vincado o seu carácter extático, o movimento de saída de si, que o prefixo ex do adjectivo anterior exprime: "Todo o meu ser suspenso", "Fez-se em redor de mim»" que "céus amenos», que «jardins amenos» serão esses, embora seja reconhecível o fundo bíblico e corânico dessas imagens. É claro, ao invés, esse sair de si; por outras palavras, não sabemos se está em jogo uma Transcendência, mas sabemos que se realiza uma trans-ascendência ${ }^{90}$.

${ }^{89}$ Comparem-se estes versos com a frase de Santa Teresa de Ávila, «Vivo já fora de mim», cit. por Maria Zambrano, "Dois Fragmentos sobre o Amor», in A Metáfora do Coração e Outros Escritos, p. 58.

${ }_{90}$ Termo conceptualizado por Jean Wahl, que designou por trans-descendência o movimento inverso, configuração terminológica que 


\section{7 - Observaçóes breves sobre o estilo de Pessanha}

A presente dissertação tem fluído tranquilamente sem um tratamento sistemático do estilo do poeta, como se deslizasse sobre a temática, o quid dos textos em detrimento do quomodo. Não se fez praticamente referência, por exemplo, na análise dos poemas, à sua substância fónica e prosódica. Todavia, a intenção náo foi a de isolar o conteúdo da forma, o que obviamente mutila sobretudo o texto poético, nem resultou de desleixo, mas da consciência de que essa vertente fundamental foi já analisada magistralmente e como que esgotado esse veio. Uma síntese das aportaçóes de Esther de Lemos, Óscar Lopes e Barbara Spaggiari encontra-se no capítulo seis da História Crítica da Literatura Portuguesa, VII, de Seabra Pereira. O pressuposto teórico destes autores é o de que o estilo é a forma da forma mentis de um autor, a articulação de uma mundividência.

Se, como tem sido demonstrado por Seabra Pereira e outros, a poesia de Pessanha patenteia profusamente a temática decadente finissecular, poderíamos ser tentados a concluir que a sua inequívoca superioridade relativamente aos seus pares de ideário decadentista e simbolista residiria no rearranjo estilístico genial dessa temática. Uma temática comum, uma mesma cordilheira, em que o «bom» estilo recorta o pico mais alto. Porém, deste modo estaríamos a reeditar em termos de crítica literária a velha questão do ovo e da galinha, quer dizer, da primazia do conteúdo ou da forma.

O modo conciliatório óbvio de contornar o problema é o de eleger o todo, a consumação ou o acabamento inextrincável de fundo e forma como aquilo que torna Pessanha primus inter pares. É porque sentiu agudamente esses núcleos temáticos que o poeta pôde articulá-los num estilo poderoso e inovador. Escolhi esse verbo recheado de escolhos, sentiu, porque, a meu ver, a poesia do autor vibra de um sincerismo irrecusável, tão distante da efusão romântica e do protesto oratório como da vontade de mistificar ou de ver a poesia como um ludismo ou um disfarce.

Sobre o carácter inovador do seu estilo poético, é interessante notar o paradoxo de ter sido o soneto a forma predilecta do autor, como se, por atracçáo de opostos, o poeta da instabilidade quisesse

lembra a dialéctica platónica (ascendente e descendente). O movimento da trans-descendência ocorre de algum modo no poema quando o sujeito do alto do seu êxtase perscruta, desfilando no deserto, em baixo, a caravana de escravos condenados. 
desta forma agarrar-se a um «lenho», fixar, conter a desordem. Mas a escolha dessa veneranda composição está perfeitamente em linha com o esboço de "poética» contido na crítica ao livro de Alberto Osório de Castro. Aí tinha louvado Pessanha a liberdade formal e métrica de que dava provas Osório de Castro ao adoptar a mais diversa paleta de formas, métricas e estróficas, irrespectivamente do seu carácter clássico ou moderno.

Curioso é que considere "mais cultas e mais difíceis» o soneto, o rondel e a ode, o que, não é temerário conjecturar, terá constituído uma forte motivação em ordem à escolha dos dois primeiros moldes para se medir ou provar enquanto poeta, aquele que desadorava, como se viu na crítica a Fogaça, o facilitismo em poesia. Tudo suporto, talvez dissesse, menos um mau poema.

É portanto no interior da configuração estrófica do soneto, injectando vinho novo em odres velhos, que ocorrem as deslocaçóes que conduzem, no dizer de Óscar Lopes, ao «maior renovo de tal forma estrófica desde o Renascimento" ${ }^{91}$. Mesmo em Antero a estrutura silogística do soneto, com o seu fecho de ouro, mantinha-se intacta, desenlaçando-se essa arquitectura na pena de Pessanha. Veja-se o soneto "Foi um dia de inúteis agonias», acumulação de versos isolados, sintacticamente autónomos. A estruturação do típico soneto camiliano tange a nota mais característica do seu estilo, além da musicalidade, "o efeito da elipse generalizada» ${ }^{92}$, como resumiu Gustavo Rubim.

Se da realidade são captáveis fragmentos efémeros, relacionáveis não logicamente, mas analogicamente, segue-se que os conectores lógico-sintácticos possam ser elididos, o adjectivo anteposto ao substantivo ou referível, ambiguamente, a mais que uma entidade, que a interrogação, a frase reticente, exclamativa, averbal prevaleçam sobre a asserçáo afirmativa, que o travessão interrompa frequentemente o abrir do leque do poema, poupando a transição explícita do objectivo para o subjectivo e vice-versa, do aqui para o além ou para o aquém, do presente para o passado ou futuro ... Eis as analogias escondidas de Esther de Lemos, o virar do avesso da Estética e da Analítica Transcendentais kantianas, segundo Óscar Lopes (na revolução copernicana de Kant, é o sujeito transcendental do conhecimento que imprime sucessão, ordem e unidade ao

${ }^{91}$ Lopes, "Camilo Pessanha», in Entre Fialho e Nemésio, p. 126. Ao nível prosódico, avulta o desvio ao decassílabo heróico ou sáfico (variando os acentos tónicos), privilegiando-se esquemas quantitativos regulares, «quadros fixos de distribuição de sílabas tónicas e átonas» (ibidem, p. 127).

${ }^{92}$ Rubim, A Inscrição Espectral..., p. 20. 
tumulto das sensaçóes...), a «aproximação ao símbolo» ${ }^{93} \mathrm{de}$ Spaggiari, cuja marcha sintáctica é marcada pela metáfora com supressão do verbo e pela comparação com supressão do conector.

A outra nota do seu estilo é a musicalidade. E, à primeira vista, este traço parece ser congruente com o primeiro. A desarticulação sintáctica, a cuidadosa poda pela elipse dos elementos estruturantes que tornam decomponível o poema em partes logicamente consequentes (as premissas e conclusão, a tese, antítese e síntese do soneto renascentista, cuja chave está no remate) favorece a ductilidade do verbo, o seu fluido melódico. Mais uma vez, é a «euritmia poética» o elemento que Pessanha destaca na poesia, logo depois de afirmá-la como "arte essencialmente subjectiva», implicitamente comparando-a à música ao evocar a fidedigna opinião dos «mais delicados cultores» da poesia, para os quais é "quase tão exclusivamente subjectiva como a música»" ${ }^{94}$, no artigo sobre o livro Flores de Coral.

Qual é então o papel, o significado da musicalidade na poesia de Pessanha? A leitura da análise efectuada por Esther de Lemos permite concluir que o som reproduz de alguma maneira o sentido, prolonga-o, ecoa-o. Por exemplo, quando evidencia, no soneto "Vénus I", que os sons sugerem ou simbolizam as cores, sucedendo aos sons claros e aos timbres vocálicos de grande variedade, na primeira quadra, que se passa à superfície das águas e onde sobressai a cor verde, e que sugerem tons diversos de vegetação marinha, os timbres «ora escuros mas agudos como a

${ }^{93}$ Spaggiari, O Simbolismo na Obra de Camilo Pessanha, p. 57.

${ }^{94}$ A propósito da larga margem de subjectividade que a música suscita aos seus receptores, como se na música tudo coubesse, se expandisse e expurgasse, transcreve-se como ilustraçáo um passo, caricatural, de Contraponto de Aldous Huxley em que uma personagem, Fanny Logan, ouvindo uma fuga de Bach, mergulha na corrente musical as suas mágoas, a sua vida, a lembrança dos seus entes queridos: «Tinha a emoção fácil, sobretudo quando se tratava de música; e quando estava comovida, não se esforçava por reprimir a comoção, mas entregava-se-lhe de todo o coração. Como aquela música era bela, como era triste e, apesar de tudo, como era reconfortante! Ela sentia dentro de si, como uma corrente de sentimento esquisito, correndo lisamente mas de maneira irresistível por todo o labirinto complexo do seu ser. O seu próprio corpo palpitava e baloiçava-se com a pulsação e a ondulação da melodia. Fanny pensou no marido: a lembrança deste veio na corrente da música - o seu Eric muito, muito querido, morto havia quase dois anos; morto - tão jovem ainda (...) A música era infinitamente triste; no entanto, consolava... Admitia tudo por assim dizer: que o pobre Eric morrera prematuramente, que sofrera com a sua doença, que lutara em deixar a vida - a música admitia tudo», Aldous Huxley, Contraponto, Lisboa, Ed. Livros do Brasil, 1972, p. 30. 
profundidade e a fosforescência azul da podridão, ora lentos e nasais, pastosos como a massa que se desfaz», na segunda quadra, de acordo com o "pútrido ventre, azul e gelatinoso»; ou quando correlaciona o ambiente claro e puro, luminoso e frio que rodeia a primeira quadra de "Vénus II» com o timbre $i$ colocado em posiçóes privilegiadas, ora na rima, ora no lugar dos acentos rítmicos. Também o leve som das sibilantes se adequa à pureza $\mathrm{e}$ limpidez das águas, etc. Nos poemas de inspiraçáo instrumental, como "Violoncelo», "Viola Chinesa», efectua-se uma verdadeira harmonia imitativa, imitando os fonemas os tons da música, aludindo a cores, a imagens.

Teríamos assim uma ilustração do harmonismo, do cratilismo do som relativamente ao sentido, ao significado. A ideia de que, pelo menos certos sons (com maior evidência na onomatopeia, na aliteração e assonância), em determinado contexto, possuem uma valência imitativa relativamente aos termos de que constituem os significantes. Não se pode é in abstracto postular correspondências unívocas entre sons e cores, sons e sentimentos, sons e objectos, como o fizeram Rimbaud e René Ghil, embora do primeiro se tenha tratado mais de uma ficção poética coberta por vestes enganadoramente científicas. É perante um poema dado que se pode aferir se os sons, ou os fono-estilemas alcançam o efeito de ecoarem o sentido, de assim o tornarem mais pregnante e mais sugestivo. A fonética subordina-se à semântica.

Se é lídimo defender o cratilismo secundário da linguagem poética em geral, como sustenta Aguiar e Silva ${ }^{95}$, na esteira de Gérard Gennette, entáo significa mais um argumento para a transitividade última da linguagem poética, pois é um impulso mimético que leva o criador a motivar o plasmar de fonemas e grafemas, seguindo o eixo semântico, «adequando-os» aos designata e aos denotata, segundo o modelo de Charles Morris.

${ }^{95}$ Aguiar e Silva, Teoria da Literatura, p. 669. 
(Página deixada propositadamente em branco) 


\section{Conclusão}

A presente dissertação não incidiu ex abrupto sobre os poemas de Camilo Pessanha, tendo efectuado um rodeio prévio sobre a poética do Simbolismo e, seguindo esta linha, destacando o principal texto crítico do autor (o que de mais parecido a uma ars poetica, não sistemática, não doutrinária, embora, o poeta escreveu). A propósito, o caso de Pessanha prova que para ser-se um grande poeta não é necessário produzir correspondentes textos doutrinários, não é necessário ser-se um grande teorizador.

$\mathrm{Na}$ poética do Simbolismo, havíamos retido, segundo a indicação de Claude Abastado e Fernando Guimarães, duas correntes de pendor oposto: a que vê na poesia a câmara ressoante do enigma metafísico do mundo, a sua decifraçáo transracional, e a que tende a voltar a linguagem poética sobre si mesma, suspendendo ou mesmo, no limite, derrogando a sua dimensão mimética ou referencial. Sustentámos que esta segunda corrente configura uma tendência, não uma teoria e uma prática conscientemente assumidas: o teclado da poesia simbolista tem as janelas da câmara mais ou menos entreabertas. Em nenhum autor estriado pelo meridiano do Simbolismo pulsa a certeza de que a sua poesia é uma engrenagem de significantes sem significados. De qualquer modo, toda a tese deste trabalho repousa na convicção de que a poesia do autor tende a flutuar na primeira daquelas correntes.

Contudo, como pode ser isso, dado o fenomenismo irredutível da sua poesia? Não é constitutiva daquela concepção da poesia a existência e a validade de um conhecimento transfenoménico, servido e alcançado pela intuição? Colocada a problemática nestes termos, a conclusão que se impóe é a de que a hipótese deste trabalho labora em erro desde o princípio. O modo de evitar esta contradição, porém, é a de reformular os dados do problema, reconhecendo na escrita de Pessanha uma poesia que quer compreender e conhecer o mundo, ou o estar-no-mundo, mas que conclui dolorosamente pela sua impossibilidade. Essa ânsia de captação cognoscitiva e a unidade que promete (o desejo de interceptar a "realidade», no limite, de coincidir com ela) é provada, a contrario, pela dor desgarradora que provoca o seu fracasso.

Ao elegermos o sentimento da melancolia como $o$ sentimento central na sua poesia (sem qualquer veleidade de originalidade, dada 
a importância que a «abulia» do poeta tem revestido nas análises de tantos críticos ${ }^{1}$ ), tentámos proteger o flanco da nossa análise da acusação de subjectivismo ou de psicologismo, defendendo que a categoria do sentimento articula intimidade e intencionalidade, interioridade e exterioridade. O sentimento é de per se ana-lógico, pois revela os modos como o sujeito é interiormente afectado, como o sujeito se sente, visando ao mesmo tempo qualidades sentidas sobre as coisas (o suporte exterior do sentir). No sentimento, náo importa apenas a impressáo do objecto, mas o próprio objecto enquanto textura de qualidades afectivas nele projectadas, coaguladas ou reconhecidas: esta dialéctica entre o dentro e o fora que se joga no sentimento pode discernir-se neste pensamento de Valéry: «Talvez nós julguemos receber de um objecto tanta vida quanto mais somos obrigados a lha dar». O sentimento é também conhecimento, intuitivo, afectivo, aparentado à Einfühlung de Baumgarten, operação pela qual ocorre identificação, ou na opinião deste, confusão entre sujeito e objecto.

Ora no seio da melancolia, no seu "dicionário» linguístico, os planos, as linhas do eu e do mundo são segmentadas e dispersas pelo redemoinho do tempo, donde resulta que esses segmentos descontínuos não se cruzam ou encaixam.

À arrepiante legenda budista que foi reveladoramente traduzida por Pessanha: «Colocando-se fronteiros dois espelhos, duas imagens se formam - qual delas a mais vazia?»², síntese perfeita da inessencialidade de tudo $^{3}$, deve acrescentar-se «o quebrar de espelhos» - as finas películas espelhadas do eu e do mundo estilhaçam-se em fragmentos, dançando em correntes desencontradas ( Imagens que passais pela retina dos meus olhos porque não vos fixais?»). Com efeito, «sob o olhar melancólico, tudo se torna melancolia, fragmentação, fluidez» ${ }^{4}$.

A reflexão posterior (o «depois») a fugazes momentos unitivos (que ocorrem, como se viu, principalmente sob o efeito da

${ }^{1}$ Já depois de termos procedido a esta escolha, lemos o artigo de Idalécio Cação, "Camilo Pessanha, poeta da melancolia», in Letras e Letras, Ano IV, 53, 1991. Este autor defende que todo um "compósito de estados de alma» se pode subsumir no sentimento da melancolia, não obstante o termo apenas aparecer nomeado uma vez, em "Paisagens de Inverno II», explicando este aparente paradoxo justamente na tendência simbolista de sugerir, não nomear.

${ }^{2}$ Pessanha, Contos, Crónicas, Cartas escolhidas ..., p. 174.

${ }^{3}$ Cf. Ofélia M. C. Paiva Monteiro, O Universo poético de Camilo Pessanha, Coimbra, 1969, separata de Arquivo Coimbrão, Vol. XXIV, 1969, p. 102.

${ }^{4}$ Franchetti, O Essencial sobre Camilo Pessanha, p. 71. 
música) descobre que não foram além de assimptotas. Além do conhecimento «sentimental», que é anterior à polaridade conscientemente delimitada de sujeito/ objecto, destaca-se aquilo que identificámos como a voz reflexiva, a que interroga o "como» e o "porquê», o poder dissociador da inteligência analítica, que tranquilamente podemos aproximar do conhecimento intelectual.

Se na ordem do sentimento, «os meus olhos querem desposar-te virgem a serena imagem», na ordem do intelecto, cava-se uma "distância sem fim que nos separa» (sujeito versus objecto), pois todas as imagens passam, fugazes. Traço algum de carpe diem se nota na poesia de Pessanha, dada a evanescência extrema da hora presente, vista como miragem que o "toque» do sujeito faz desaparecer. $\mathrm{Na}$ terminologia de Esther de Lemos, o poeta aspira à coincidência, conseguindo apenas a intercepção, que é desmontada a posteriori, reflexivamente, como uma ilusáo.

Porém, desejaria colocar agora o acento na ânsia de sentido, de «encher a alma». Óscar Lopes observou que já muito se interrogava Pessanha, embora para estender o fio desta feição problematizante de Pessanha a Pessoa, que a complicará. As interrogaçóes que nos interessam são aquelas introduzidas por "Quem», onde lateja a inquietação existencial do porquê último da vida, como se quisesse apurar responsabilidades, como se quisesse que alguém lhe respondesse. A interpelação supóe um agente pessoal, que pudesse ser identificável e imputável. Avultam as lancinantes interrogaçóes de «Quem poluiu, quem rasgou os meus lençóis de linho?», e outras indagações: «Quem vos desfez, formas inconsistentes/ Por cujo amor escalei a muralha», "Quem há-de remi-la/ Quem sabe a dor que sem razão deplora?», «Quem as esparze? - quanta flor! - do céu,/ Sobre nós os dois, sobre os nossos cabelos?», "Roteiro da vida,/ quem é que o traçou», encastoadas, respectivamente, em «Depois da luta, depois da conquista», "Ao longe os barcos de flores», "Floriram por engano as rosas bravas» e "Roteiro da Vida». É o enigma, versão individualizada, da Esfinge: "Dizei-me quem sou...».

Portanto, o poeta é um mistério para si mesmo. Contudo, é próprio de um abúlico lançar estas frementes interrogaçóes?

Tudo depende da pré-compreensão que se tenha deste termo. Se abulia significasse a amarra a uma inactividade total, a represa de toda a inquirição, de todo o desabafo, a redução a um estado vegetativo, então Pessanha não pertenceria a essa espécie de 
abúlicos, se é que existem ${ }^{5}$. João Camilo ${ }^{6}$ tem um artigo em que confronta as explicaçóes da «abulia» (as aspas são colocadas cautamente pelo crítico no título do seu artigo) de Pessanha em Esther de Lemos e Óscar Lopes.

$\mathrm{Na}$ primeira, a incapacidade de desposar o real residia no carácter ou temperamento do autor, no segundo na estrutura e valores burgueses que configuram a realidade e à qual o poeta não se acomoda. O poeta não está desiludido de antemão, vacinado contra os impulsos de «viver», «amar», "compreender» e "conhecer», como ao longo do seu estudo reconhece Esther de Lemos. É a repetição das experiências frustrantes, a sua sedimentaçáo amarga, que levam implicitamente o sujeito poético a concluir que, antecipando o que era corrente dizer-se na época do triunfo do existencialismo, a condição humana e o mundo são absurdos porquanto a irremissível dor de viver leva a desejar a morte, vista como cessação da dor. João Camilo comenta que «a falta de acção, de paixão e de arrebatamento só em parte, e apesar das aparências, é verdadeira», aduzindo o poema «Branco e Vermelho» como prova do desejo arrebatado da morte e o "Poema Final» como um elogio «apaixonado» da não-existência. Porém, supomos que não eram estas as direcçóes da «vontade de acção, paixão e arrebatamento verdadeiro», cuja ausência Lemos detectava em Pessanha. A união almejada é com a vida. E é porque não o consegue, "alma egoísta e fraca», que a sua poesia permanece lírica, alimentada por essa insatisfação, não se transmutando em poesia épica, cujo esboço, falhado projecto, se encontra em «S. Gabriel» (não há epopeia sem um estado de exaltação, de predisposição para a glória... $)^{7}$.

${ }^{5}$ Já Ofélia M. C. Paiva Monteiro notara que «o homem abúlico, desistente e finalmente opiómano compusera, por exemplo, em Coimbra, alguns contos onde não estava ausente uma intençáo social e fora em 1916 recebido no Supremo Conselho da Maçonaria Portuguesa» (O. P. Monteiro, op. cit., pp. 20, 21). Poderíamos, nesta linha, apontar, como faz João Camilo ( de Camilo Pessanha", in Persona, 10, Porto, 1984, p. 35), a complexidade da sua poesia como contravenção de uma abulia irredutível: «A variedade rítmica da poesia de Camilo Pessanha (...) traduz não só a necessidade de exprimir no espaço limitado do poema toda a riqueza e complexidade, todas as contradiçóes de um real complexo e vivido problematicamente e com obsessão, mas também a negação surpreendente de uma renúncia e de uma desistência que parece dar o tom geral aos poemas de Clepsidra».

'João Camilo, "Sobre a «abulia» de Camilo Pessanha", in Persona, 11/ 12, 1985.

${ }^{7}$ Cf. Lemos, op. cit., pp. 176-178. 
Em alternativa a esta explicação confinada à esfera da psicologia individual, centra Óscar Lopes a causa da «abulia» do poeta, menos nele próprio, do que na realidade, distorcida pela ideologia burguesa. Como diz João Camilo, o ilustre historiador da literatura portuguesa "deixa-nos acreditar que a incapacidade de viver e de amar do sujeito dos poemas de Clepsidra é apenas incapacidade de viver e de amar de determinada maneira, segundo um determinado código de valores, e sobretudo no interior de uma sociedade historicamente bem definida $\iota^{8}$. Lopes não perde a lucidez quando concede que a obra de Pessanha é omissa «em tudo o que respeita às possibilidades de se refazer o mundo ou de se refazerem as relaçóes entre os homens que condicionam a acção humana sobre o mundo». Mas entra, a nosso ver, em conjectura descontrolada quando traça uma linha de continuidade entre o "cepticismo categorial de Pessanha», com a decorrente "dissolução dos pólos sujeito e objecto", e "a crítica estruturalista à ideologia burguesa herdada do século XIX», dando a entender que aquele «eu» de que o sujeito da poesia de Pessanha se quer desprender é identificável com o «moi» que a psicanálise estrutural de Lacan desmontou como «forma narcísica típica de alienação psíquica». Postulando que entre eu e mundo se interpóe parasitariamente a «ideologia», Lopes salva a realidade, direccionando a flecha d' 'o cepticismo radical, a abulia, a negatividade de Pessanha» para o alvo de «uma ideologia morta»?

Voltando ao ponto anterior a este breve excurso, tínhamos realçado as perguntas que começavam por «quem» em vez do anónimo «que» e acrescentáramos que o esclarecimento visaria em última instância o ser e a história do próprio sujeito - «Dizei-me quem sou». Tínhamos arriscado a tese de que se há unidade na Clepsidra ela é conferida pelo «eu» do sujeito, um eu, como apontou parenteticamente Óscar Lopes, «menos desintegrado do que pretende» ${ }^{10}$.

Emanuel Kant, numa síntese célebre, tinha formulado a tarefa da filosofia em três questôes fundamentais: o que podemos conhecer, o que podemos esperar, o que devemos fazer, redutíveis à grande e única questão: o que é o homem.

No remate da introdução a este trabalho, pretendíamos esclarecer acerca de quê falava a poesia de Pessanha. Talvez a

${ }^{8}$ João Camilo, op. cit., p. 68

${ }^{9}$ Cf. Óscar Lopes, "Pessanha, o quebrar dos espelhos», in Ler e Depois, pp. 208, 209.

${ }^{10}$ Óscar Lopes, "Camilo Pessanha», in Entre Fialho e Nemésio, p. 123. 
grande questão seja: "Quem sou eu?», versão lírica da grande questáo kantiana, em que se inclui o que posso conhecer e o que posso esperar. Contudo, aquilo que invoca para a dilucidaçáo do seu mistério, "dizei-me quem sou", são as "Miragens do nada", espelho que nada reflecte senão o nada. Daí a dor de não ser capaz de conhecer e de esperar.

"Eu sou o aborto de uma grande beleza», tinha-se definido Pessanha perante Carlos Amaro. Uma grande beleza não difusiva, que náo elevou o sujeito à sua altura. Com efeito, a grande beleza da sua poesia não logrou rasgar uma saída do abismo, quer dizer, abrir-lhe a porta para um sentido último e esperançoso da existência pessoal. 


\section{Bibliografia}

\section{GeraL}

Catroga, Fernando, «Portugal como "corpo” e "alma” (sécs. XIX/ $\mathrm{XX}$ », in Revista de História das Ideias, Vol. 28, Coimbra, 2007, pp. 245-275.

Dostoiéwski, Fiódor, Cadernos do Subterrâneo, Lisboa, Assírio \&Alvim, 2000.

Dufour, Pierre, “"Les Fleurs du Mal», Dictionnaire de Mélancolie”, in Littérature, No 72, 1988, pp. 30-54.

Eco, Umberto, Os Limites da Interpretação, Lisboa, Difel, 1992.

Greene, Graham, Monsenhor Quixote, Lisboa, Círculo de Leitores, 1984.

Guimarães, Fernando, Poética do Simbolismo em Portugal, Lisboa, INCM, 1990.

Guimarães, Fernando, Simbolismo, Modernismo e Vanguardas, 2a ed., Porto, Lello, 1992.

Guimarães, Fernando, Simbolismo, Saudosismo e Modernismo, Antologia de Poesia Portuguesa, Vila Nova de Famalicão, Ed. Quasi, 2001.

Gusdorf, Georges, L'Homme Romantique, Paris, Éditions Payot, 1984.

Habermas, Jürgen, O Discurso Filosófico da Modernidade, Lisboa, Publicações Dom Quixote, 1990.

Haugen, Arne Kjell, «Baudelaire: Le Rire et Le Grotesque», in Littérature, no 72, 1988, pp. 12-29.

Huxley, Aldous, Contraponto, Lisboa, Ed. Livros do Brasil, 1972.

Lourenço, Eduardo, Heterodoxia I, Lisboa, Gradiva, 2005.

Lourenço, Eduardo, Heterodoxia II, Lisboa, Gradiva, 2006.

Maulpoix, Jean-Michel, "Exclamation et Développement», in Littérature, no 72, 1988, pp. 55-61. 
Morão, Paula, «Edição crítica de textos modernos e contemporâneos: algumas questóes gerais, seguidas de notas breves sobre Clepsidra», in Românica, 15, 2006.

Nemésio, Vitorino, Quase que os vi viver, Lisboa, Bertrand, 1985.

Osvaldo Manuel Silvestre e Pedro Serra, «Desaprender (com) a História», in Século de Ouro Antologia Critica da Poesia Portuguesa do Século XX, Coimbra, 2003, pp. 15-65.

Palmer, Richard E., Hermenêutica, Lisboa, Edições 70, 1986.

Pereira, José Carlos Seabra, «Servanda Lusitana! (Ideia e Representação de Portugal na Literatura dos Séculos XIX e XX)», in Revista de História das Ideias, Vol. 28, Coimbra, 2007, pp. 527-566.

Pereira, José Carlos Seabra, O Neo-romantismo na Poesia Portuguesa: 1900-1925, Tese de Doutoramento apresentado à F.L.U.C., Coimbra, 1999.

Pereira, José Carlos Seabra, Decadentismo e Simbolismo na Poesia Portuguesa, Dissertação de Licenciatura em Filologia Românica, Coimbra, 1972.

Pereira, José Carlos Seabra, Decadentismo e Simbolismo na Poesia Portuguesa, Coimbra, Centro de Estudos Românicos, 1975.

Pessoa, Fernando, Obras em prosa de Fernando Pessoa, Introdução, Organização e Notas de António Quadros, Lisboa, Publicaçôes Europa-América, 1986.

Pessoa, Fernando, Páginas Íntimas e de Auto-interpretação, ed. por Jacinto do Prado Coelho e Georg Rudolf Lind, Lisboa, 1966.

Pessoa, Fernando, Poesias Inéditas (1919-1930), Lisboa, Ática, 1990.

Pessoa, Fernando, Poesias, Lisboa, Ática, 1992.

Reis, Carlos, Técnicas de Análise Textual, Coimbra, Almedina, 1981.

Ricoeur, Paul, Ideologia e Utopia, Lisboa, Ediçóes 70, 1991. 
Ricoeur, Paul, Metáfora Viva, Porto, Ed. Rés, 1983.

Ross, David, Aristóteles, Lisboa, Publicaçôes Dom Quixote, 1987.

Sá-Carneiro, Mário de, Poesias, Lisboa, Ática, 1991.

Silva, Vítor Manuel de Aguiar e, Teoria da Literatura, Coimbra, Almedina, 1988.

Silva, Vítor Manuel de Aguiar e, "Comentário a «Morte ao MeioDia» de Ruy Belo" in Século de Ouro Antologia Crítica da Poesia Portuguesa do Século XX. Organização de Osvaldo Manuel Silvestre e Pedro Serra, Coimbra, 2003, pp. 252-256.

Simões, João Gaspar, «Estudo crítico», in Poesias, de Mário de Sá-Carneiro, Lisboa, Ática, 1991, pp. 11-47.

Wellek R. e A. Warren, Teoria da literatura, 2a ed., Lisboa, Publicaçóes Europa-América, 1962.

Zambrano, Maria, A Metáfora do Coração e outros Escritos, Lisboa, Assírio \& Alvim, 1993.

\section{ESPECÍFICA}

a) do autor

Pessanha, Camilo, Contos, Crónicas, Cartas escolhidas e Textos de temática chinesa, Organização e Notas de António Quadros, Lisboa, Publicaçôes Europa América, 1988.

Pessanha, Camilo, Obras de Camilo Pessanha, Clepsidra e poemas dispersos, Introdução biográfica e crítica, Organização e Notas de António Quadros, 2a ed., Lisboa, Publicaçóes Europa-América, 1988.

Pessanha, Camilo, Clepsidra e outros poemas, Ediçăo crítica, fixação do texto, introduçáo e notas de Barbara Spaggiari, Porto, Lello Editores, 1997.

Pessanha, Camilo, Clepsidra, Estabelecimento de texto, introdução crítica, notas e comentários por Paulo Franchetti, Lisboa, Relógio D’Água Editores, 1995. 


\section{b) sobre o autor}

Andrade, Eugénio de, «Camilo Pessanha, o mestre», in Persona, 10, Porto, 1984, p. 10.

Barahona, António, «A Chave da Clepsydra», in Clepsydra Poemas de Camilo Pessanha, Lisboa, Assírio \& Alvim, 2003, pp. 137-183.

Bento, José, «Outra vez o tema da água na poesia de Camilo Pessanha», in Persona, 10, 1984, pp. 12-16.

Cação, Idalécio, "Camilo Pessanha, poeta da melancolia», in Letras e Letras, Ano IV, 53, 1991.

Camilo, João, «A Clepsidra de Camilo Pessanha», in Persona, 10, Porto, 1984, pp. 20-33.

Camilo, João, «Sobre a «abulia» de Camilo Pessanha», in Persona, 11/ 12, Porto, 1985, pp. 67-70.

Cesariny, Mário, «Tudo (ou nada) é Camilo Pessanha», in Persona, 10, 1984, Porto, p. 11.

Coelho, Jacinto do Prado, «De Verlaine a Camilo Pessanha e a Fernando Pessoa», in Ao Contrário de Penélope, Lisboa, Bertrand, 1976, pp. 209-214.

Franchetti, Paulo, O Essencial sobre Camilo Pessanha, Imprensa Nacional-Casa Da Moeda, 2008.

Garcez, Maria Helena Nery, «A inscrição e a Clepsidra (Uma leitura da poesia de Camilo Pessanha)», in Letras e Letras, Ano IV, 53, 1991.

Garcia, Mário, «Sobre Camilo Pessanha», in Brotéria, Vol. 122, No 4, 1986, pp. 386-395.

Gomes, Álvaro Cardoso, A metáfora cósmica em Camilo Pessanha, S. Paulo, Faculdade de Filosofia, Letras e Ciências Humanas, 1977.

Klobucka, Anna, «A (de)composição de Vénus: reflexôes sobre dois sonetos de Camilo Pessanha, in Colóquiol Letras, $\mathrm{n}^{\circ}$ 104/105, 1988, pp. 38-45.

Laranjeira, Pires, «Música e abulia em Camilo Pessanha», in Persona, 10, 1984, pp. 37-40. 
Lemos, Esther de, $A$ «Clepsidra» de Camilo Pessanha, 2a ed., Lisboa, Editorial Verbo, 1981.

Lopes, Óscar, «Pessanha, o quebrar dos espelhos», in Ler e Depois, $3^{\mathrm{a}}$ ed., Porto, Inova, 1970, pp. 198-210.

Lopes, Óscar, "Camilo Pessanha», in Entre Fialho e Nemésio, Vol. I, Lisboa, INCM, 1987, pp. 117-137.

Lopes, Teresa Coelho, "Apresentação crítica", in Clepsidra de Camilo Pessanha, 2a ed., Lisboa, Ed. Comunicação, 1983, pp. 11-55.

Margarido, Alfredo, "Camilo Pessanha, poeta da escrita», in Persona, 11/ 12, Porto, 1985, pp. 76-84.

Martins, Fernando Cabral, «Pessanha e Sá-Carneiro: intersecções», in Colóquio/ Letras, no 117/118, 1990, pp. 193-199.

Monteiro, Ofélia M. C. Paiva, O Universo poético de Camilo Pessanha, Coimbra, separata de Arquivo Coimbrão, Vol. XXIV, 1969, pp. 83-109.

Nava, Luís Miguel, «A propósito duma imagem de Pessanha», in Persona, 10, 1984, pp. 34-36.

Oliveira, António Falcão Rodrigues de, O Simbolismo de Camilo Pessanha, Lisboa, Ática, 1979.

Osório, António, O Amor de Camilo Pessanha, Mafra, Edições Elo, 1982.

Osório, João de Castro, «Introdução Crítico-Bibliográfica», in Clepsidra e outros poemas, Lisboa, Ática, 1969, pp. 11-125.

Pâris-Montech, Christine, L'Imaginaire de Camilo Pessanha Résonances Fin-de-Siècle et Hantises Individuelles, Paris, Centre Culturel Calouste Gulbenkian, 1997.

Pereira, José Carlos Seabra, «Camilo Pessanha e a Transmutação Simbolista», in História Crítica da Literatura Portuguesa, Vol. VII, 2a ed., Lisboa, Verbo, 2004, pp. 127-139.

Pereira, José Carlos Seabra, «Sentido e alcance do Simbolismo na Clepsidra», in O Comércio do Porto, 13-1-1980.

Pereira, José Carlos Seabra, "Comentário a «Ao Longe Os Barcos De Flores»" de Camilo Pessanha", in Século de Ouro Antologia 
Crítica da Poesia Portuguesa do Século XX, Organização de Osvaldo Manuel Silvestre e Pedro Serra, Coimbra, 2003, pp. 263-274.

Quadros, António, "Introdução biográfica e crítica», in Obras de Camilo Pessanha, Clepsidra e poemas dispersos, Lisboa, Publicaçóes Europa-América, 1988, pp. 23-66.

Reckert, Stephen, "A fono-estilística de Camilo Pessanha», in Colóquio/Letras, no 129/130, pp. 87-96.

Rubim, Gustavo, Experiência da Alucinação Camilo Pessanha e a Questão da Poesia, Lisboa, Ed. Caminho, 1993.

Rubim, Gustavo, "A alucinação obsidiante», in Colóquio/ Letras, no $129 / 130$, pp. 97-114.

Rubim, Gustavo, «Imaginar Pessanha», in Arte de Sublinhar, Coimbra, Angelus Novus, 2003, pp. 39-43.

Rubim, Gustavo, A Inscrição Espectral: Poética do Vestígio em Camilo Pessanha, Dissertação de Doutoramento, Universidade Nova de Lisboa, Lisboa, 1998.

Saraiva, Arnaldo, "Fonte contínua de exaltação estética», in Persona, 10, Porto, 1984, pp. 3, 4.

Simões, João Gaspar, Camilo Pessanha, Lisboa, Arcádia, 1967.

Spaggiari, Barbara, «Pessanha e Pessoa: alle origine del simbolismo di Pessoa», in Persona, 10, 1984, pp. 5-9.

Spaggiari, Barbara, O Simbolismo na Obra de Camilo Pessanha, Lisboa, Instituto de Cultura e Língua Portuguesa, 1982. 


\section{ÍnDICE ONOMÁSTICO}

Abastado, Claude - 46, 139

Abbagnano, Nicola - 23

Adam, Paul - 32

Alain, Émile Chartier, dito 15

Almeida, Fialho de - 48, 57

Amaro, Carlos - 41, 51, 72, 82, 113, 144

Amiel, Henri - 85

Andrade, Eugénio de - 9

Anselmo, S. - 62

Aurier, Albert - 35

Austin, J. L. - 25

Ávila, Santa Teresa de - 133

Bachelard, Gaston- 16, 78

Bacon, Francis - 36

Baju, Anatole - 34

Barahona, António -30, 31

Barrès, Maurice - 32

Barthes, Roland - 15, 45

Bataille, Georges - 41

Baudelaire, Charles -27, 32, 40, 42, 60, 65, 99, 106, 117

Baudry, Jean-Louis - 19

Baumgarten, Alexander - 140

Beardsley, C. M. - 18

Bergson, Henri - 30, 120, 123

Blake, William - 36

Blanchot, Maurice - 62

Bloom, Harold - 9, 29

Bloy, Léon - 32

Boehme, Jacob - 83

Bos, Charles du - 85

Bourget, Paul - 32, 47

Branco, Camilo Castelo - 57

Braque, Georges - 17

Buber, Martin - 100

Byron, Lord - 36

Cação, Idalécio - 140
Caeiro, Alberto - 124

Camilo, João - 97, 142, 143

Camóes, Luis de - 7, 9, 19, 88

Campos, Álvaro de - 9, 56

Camus, Albert - 17

Carnap, Rudolf - 81, 83

Carus, Carl Gustav - 83

Castro, Alberto Osório de - 9, $20,49,51,52,53,60,72$, $103,116,121,123,130$, 135

Castro, Eugénio de - 34

Catroga, Fernando - 59

Cerejeira, Cardeal - 106

Cervantes, Miguel de - 19

Cesariny, Mário - 8

Chevalier, Jean - 126

Claudel, Paul - 27

Coelho, Henrique Trindade - 9

Coelho, Jacinto do Prado 111

Cohen, Jean - 45

Copérnico, Nicolau -36

Coppée, François - 34

Culler, Jonathan - 25

Deleuze, Gilles - 23

Derrida, Jacques - 21, 22, 23, 24, 25

Descartes, René - 55, 62

Dostoiéwski, Fiódor - 19, 55, 106

Duarte, Lélia Maria Parreira 86

Dufour, Pierre - 106, 111

Durand, Gilbert - 13, 75, 120, 127

Eckhart, Mestre - 83

Eco, Umberto - 17, 18, 22, 23, $37,43,48$ 
Eliot, T. S - 27

Epicuro - 117

Fénéon, Félix - 32

Ferro, António - 8

Fogaça, António - 53

Foucault, Michel - 23

France, Anatole - 132

Franchetti, Paulo - 8, 37, 38, 40, 50, 71, 140

Frege, Gottlob - 15, 47

Galileu - 37

Garção, Mayer - 8

Garcez, Maria Helena Nery 72

Garcia, Mário - 93, 108

Gasset, Ortega y - 17

Gennette, Gérard - 137

Gheerbrant, Alain - 126

Ghil, René - 32, 35, 52, 137

Gomes, Álvaro Cardoso -13, $37,45,61,75,76$

Gourmont, Rémy de - 32

Greene, Graham - 59

Guimarães, Fernando - 28, 29, $32,34,35,40,41,46,48$, 50, 139

Gusdorf, Georges - 72, 79, 83, 84,85

Habermas, Jürgen - 21, 22, 23, 24, 25

Hartmann, Eduard von - 37, 39

Haugen, Arne Kjell - 99

Hegel, G. W. F. - 20, 26, 33

Heidegger, Martin - 21, 22, 24, 25, 29, 46, 86

Heine, Heinrich - 32

Hemsterhuis - 84

Hirsch, E. D. - 16

Homero - 19

Hugo, Victor - 33, 42

Huret, Jules - 35

Huxley, Aldous - 136

Huxley, Thomas Henry - 56

Huysmans, J.-K. - 32, 42

Ingarden, Roman - 27

Jakobson, Roman - 15, 17, 18, 25, 109

James, Henry - 110
Jaspers, Karl - 22, 29, 86, 87

João, S. - 65

Johnson, W. R. - 20

Joyce, James - 43

Jung, Carl - 46, 75, 76

Junqueiro, Guerra - 57

Kafka, Franz - 30

Kahn, Gustave - 31

Kant, Emmanuel - 74, 136, 143

Kepler, Johannes - 37

Kierkegaard, Sören - 86

Kipling, Rudyard- 88

Klobucka, Anna - 95

Klossovsky, Pierre - 23

Krysinska, Marie - 32

Lacan, Jacques - 143

Lacoue-Labarthe - 49

Laforgue, Jules - 32, 36

Lamartine, Alphonse de - 54

Laplace, Pierre - 74

Laranjeira, Manuel - 59

Laranjeira, Pires - 17

Le Roy - 32

Leal, Gomes - 40

Lemos, Esther de - 7, 8, 14, 30, $44,54,64,75,76,79,82$,

$87,88,94,95,123,124$, 125, 126, 134, 136, 137, 141,142

Lima, Ângelo de - 73

Lisle, Leconte de - 33

Lopes, Óscar - 8, 14, 30, 43, 50, 64, 87, 94, 112, 115, $134,135,136,141,142$, 143

Lopes, Tereza Coelho - 63

Lorrain, Jean - 32

Loti, Pierre - 39

Lourenço, Eduardo - 17, 57, 105, 106, 116

Maeterlink, Maurice - 32, 64

Mallarmé, Stéphane - 22, 27 , 28, 32, 35, 36, 43, 46, 47, 48, 74, 105

Malraux, André - 56

Man, Paul de - 25

Marcel, Gabriel - 29

Margarido, Alfredo - 20 
Martins, Cabral Fernando - 9, 19, 50

Marx, Karl - 30, 117

Mauclair, Camille - 31

Maulpoix, Jean-Michel - 75

Merquior, José Guilherme - 49

Merrill, Stuart - 32, 49

Mesquita, Carlos de - 40

Michaud, Guy - 34, 76

Milosz, Oscar W. - 116

Milton, John - 36

Mockel, Albert - 35, 44

Montalvor, Luís de - 34, 42

Monteiro, Ofélia M. C. Paiva 140,142

Morão, Paula - 17

Moréas, Jean - 32, 34

Morice, Charles - 32, 35, 43

Morris, Charles - 137

Mounier, Emmanuel - 56

Nava, Luís Miguel - 27, 41

Nemésio, Vitorino - 40

Newton, Jonh - 37

Nietzsche, Friedrich - 21, 40, 123

Nobre, António - 97

Nordau, Max - 42

Novalis, Friedrich von Hardenberg - 27, 84, 85

Ohmann, Richard - 25

Oliveira, António Falcão Rodrigues de - 71

Oliveira-Soares, António de 34

Orwell, Georges - 56

Osório, Ana de Castro - 9

Osório, António - 9

Osório, João de Castro - 7, 19, 20, 72, 106

Paracelso - 37

Pâris-Montech, Christine - 7, 13, 14, 37, 59, 74, 86, 96, 119, 120, 126, 127

Pascoaes, Teixeira de - 31, 32

Paulo, S. - 23

Paz, Octavio - 32, 65

Péladan, Joséphin - 32

Pereira, José Carlos Seabra - 13, 31, 32, 33, 34, 35, 36, 37,
40, 43, 44, 46, 49, 52, 58, 59, 60, 61, 64, 67, 74, 88, 134

Perrone-Moisés, Leila - 112

Pessanha, José Benedito - 38

Pessoa, Fernando - 7, 8, 9, 16, $17,19,29,31,35,42,50$, $64,65,73,105,111,130$, 141

Platão - 46, 117

Pound, Erza - 45

Pratt, Mary L. - 25

Praz, Mário - 41

Proust, Marcel - 121, 131

Quadros, António - 8, 13, 34, 50, 108

Quental, Antero de - 32, 37, 39, 106

Quillard, Pierre - 32

Raymond, Émile-Georges - 34

Reckert, Stephen - 75, 109

Régnier, Henri de - 32, 44

Reis, Carlos - 108

Richards, I.A. - 28

Ricoeur, Paul - 18

Rimbaud, Arthur - 27, 28, 137

Rodenbach, Georges - 32

Rorty, Richard - 48

Rosenberg, Harold - 49

Rougemont, Dennis de - 51

Rubim, Gustavo - 13, 14, 19, 20, 21, 35, 57, 76, 77, 82, 96, 97, 135

Ruysbroeck, Jan de - 40

Sá-Carneiro, Mário de - 9, 56, 73, 100

Sade, Marquês de - 61

Saint-Pol-Roux - 32

Samain, Albert - 32

Sampaio, Alberto - 106

Saraiva, Arnaldo - 7, 64

Sartre, Jean-Paul - 17, 29, 117

Schlegel, August-Wilhelm - 7

Schlegel, Frédéric - 83

Schleiermacher, Friedrich - 84

Schopenhauer, Arthur - 37, 38, $39,40,41$

Searle, John - 22, 25

Serra, Pedro - 28 
Shakespeare, William - 19

Sheller, Max - 82

Silva, Vítor Manuel de Aguiar e - 20, 105, 137

Silveira, Pedro da -8

Silvestre, Osvaldo Manuel - 28

Simóes, João Gaspar - 13, 19, $30,45,102,103$

Spaggiari, Barbara - 13, 17, 26, $30,37,41,42,44,61,71$, $72,93,120,134,136$

Stevenson, Robert-Louis - 115

Swedenborg, Emmanuel - 40

Taine, Hippolytte - 52

Teógnis - 74

Todorov, Tzvetan - 45

Unamuno, Miguel de - 59

Valéry, Paul - 17, 44, 47, 48, $49,75,140$

Van Lerberghe, Charles - 32

Vasconcelos, Henrique de - 39

Vattimo, Gianni - 48

Verde, Cesário - 30

Verhaeren, Émile - 32

Verlaine, Paul - 29, 31, 32, 36, $51,99,111$

Vicaire, Gabriel - 34

Vielé-Griffin, Francis - 32

Wahl, Jean - 134

Warren, Austin - 75

Weber, Jean-Paul - 108

Wellek, René - 75

Whitmann, Walt - 48

Wimsatt, W. K. - 18

Zambrano, Maria - 79, 83, 84, 105,134

Zola, Émile - 42 
A Vontade é uma potência cega, que não segura qualquer balança. A satisfação do desejo, de qualquer desejo, é como uma esmola que se dá a um mendigo para ele sobreviver durante um dia, regressando logo depois à indigência habitual. O desejo humano, multiforme, tem como o gouffre baudelairiano a sede de Tântalo.

«Eu sou o aborto de uma grande beleza», tinha-se definido Pessanha perante Carlos Amaro. Uma grande beleza não difusiva, que não elevou o sujeito à sua altura. Com efeito, a grande beleza da sua poesia não logrou rasgar uma saída do abismo, quer dizer, abrir-lhe a porta para um sentido último e esperançoso da existência pessoal. 